\title{
Magmatic evolution of the Peñón Rosado granite: Petrogenesis of garnet-bearing granitoids
}

\author{
J.A. Dahlquist ${ }^{\text {a,* }}$, C. Galindo ${ }^{\text {b }}$, R.J. Pankhurst ${ }^{\text {c }}$, C.W. Rapela ${ }^{\text {d }, ~ P . H . ~ A l a s i n o ~}{ }^{\text {a }}$, \\ J. Saavedra ${ }^{\text {e }}$, C.M. Fanning ${ }^{\mathrm{f}}$ \\ ${ }^{a}$ CRILAR-CONICET, Entre Ríos y Mendoza S/N. 5.301 Anillaco, La Rioja, Argentina \\ b Dpto. de Petrología y Geoquímica, Universidad Complutense, 28040 Madrid, Spain \\ ${ }^{\mathrm{c}}$ British Geological Survey, Keyworth, Nottingham NG125GG, UK \\ ${ }^{d}$ Centro de Investigaciones Geológicas, UNLP, Calle 1 No 644, 1900 La Plata, Argentina

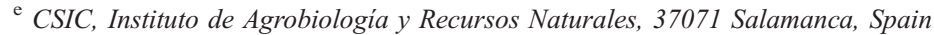 \\ ${ }^{\mathrm{f}}$ Research School of Earth Sciences, the Australian National University, Canberra, Australia
}

Received 30 June 2005; accepted 7 July 2006

Available online 6 September 2006

\begin{abstract}

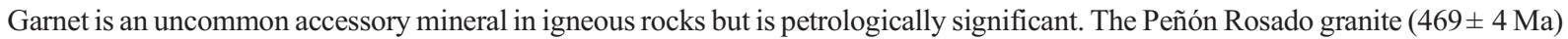
at Cerro Asperecito is an S-type granite that contains an unusual amount of magmatic garnet. Combined petrology, chemistry/ mineralogy and whole-rock geochemistry indicates that the magma was produced by partial melting of the surrounding metasedimentary rocks and subsequent differentiation by fractional crystallization during emplacement, with garnet occurring throughout the crystallization sequence. Three facies are recognised: PRG1 $\left(\mathrm{SiO}_{2}=65.70 \%\right)$ represents cumulates, PRG2 $\left(\mathrm{SiO}_{2}=70.88 \%\right)$ represents a differentiated melt, and PRG3 $\left(\mathrm{SiO}_{2}=74.59 \%\right)$ a residual melt. The fractionation of Mn in garnet and the proportion of garnet crystallizing are roughly controlled by the evolving composition of the different granitic facies. Geothermobaric calculations reveal an initial crystallization temperature of $764^{\circ}-792^{\circ} \mathrm{C}$ and a pressure of $5.9-6.0 \mathrm{~kb}$, indicating that the parental magma was emplaced at middle crustal depths $(\sim 19-20 \mathrm{~km})$ in moderate-low magmatic temperature conditions. $\mathrm{Major}\left(\mathrm{CaO}, \mathrm{Na} \mathrm{O}_{2}, \mathrm{~K}_{2} \mathrm{O}\right)$ and trace element $(\mathrm{Rb}, \mathrm{Sr}, \mathrm{Ba})$ contents in the Peñón Rosado granite strongly suggest anatexis was the outcome of $\mathrm{H}_{2} \mathrm{O}$-fluxed melting of metagreywacke, with heat input from a major metaluminous suite. Our studies reveal that garnet formed by direct crystallization from peraluminous magma in equilibrium with solid phases such as biotite and white mica. We confirm previous suggestions that zoning in garnet is strongly temperature-dependent. Thus, magmatic garnets in granitic rocks crystallized above $\sim 700{ }^{\circ} \mathrm{C}$ have "spessartine inverse bell-shaped profile" or are unzoned, whereas garnet exhibiting "spessartine bell-shaped profile" must be considered of metamorphic origin (i.e., xenocrystic) or formed in very felsic magmas $\left(\mathrm{SiO}_{2}=73-76 \%\right)$ crystallizing below $\sim 700{ }^{\circ} \mathrm{C}$.
\end{abstract}

(C) 2006 Elsevier B.V. All rights reserved.

* Corresponding author.

E-mail address: jdahlquist@crilar-conicet.com.ar (J.A. Dahlquist).

\section{Introduction}

Igneous garnet mostly occurs in pegmatites and aplite dykes (e.g., Leake, 1967; Manning, 1983; Deer et al., 1992), although its occurrence is also reported in some 
felsic to very felsic (i.e., $\mathrm{SiO}_{2} \geq 70 \%$ ) peraluminous granitoids (e.g., Leake, 1967; Allan and Clarke, 1981; Miller and Stoddard, 1981; du Bray, 1988; Hogan, 1996; Kebede et al., 2001). Magmatic garnet is uncommon, but can help constrain host granitoid petrogenesis (du Bray, 1988) as well as being a useful geothermobarometry.

In this paper, we assess the petrography, mineral chemistry, bulk major and trace element composition, isotope ratios, and geochronology of the Peñón Rosado granite, which contains an unusual amount of garnet formed at various stages during crystallization (silica range $65.70-74.59 \%$ ). Remarkably, the presence of garnet in granitic rocks of intermediate composition $\left(\mathrm{SiO}_{2} \sim 65.70 \%\right)$ is rare. Our study contributes to understanding granitic rocks of intermediate composition that house magmatic garnet and explain the occurrence of garnet throughout the crystallization sequence. We explore factors such as the origin of magmatic garnet, its zoning pattern, the source, initial pressure and temperature, and compositional evolution of the host magma and the overall petrogenetic process.

\section{Geological setting}

The Sierras Pampeanas of NW Argentina are mountainous ranges, composed of metamorphic rocks intruded by diverse Palaeozoic igneous rocks, elevated since the Miocene by compressional (Andean) tectonics (e.g., Jordan and Allmendiger, 1986) (Fig. 1). The igneous rocks were generated in three main orogenic events: (a) Pampean (latest Neoproterozoic to Mid-Cambrian), (b) Famatinian (Early to Mid-Ordovician), and (c) Achalian (Late Devonian to Early Carboniferous) (Rapela et al., 1998a,b; Pankhurst et al., 1998; Sims et al., 1998;

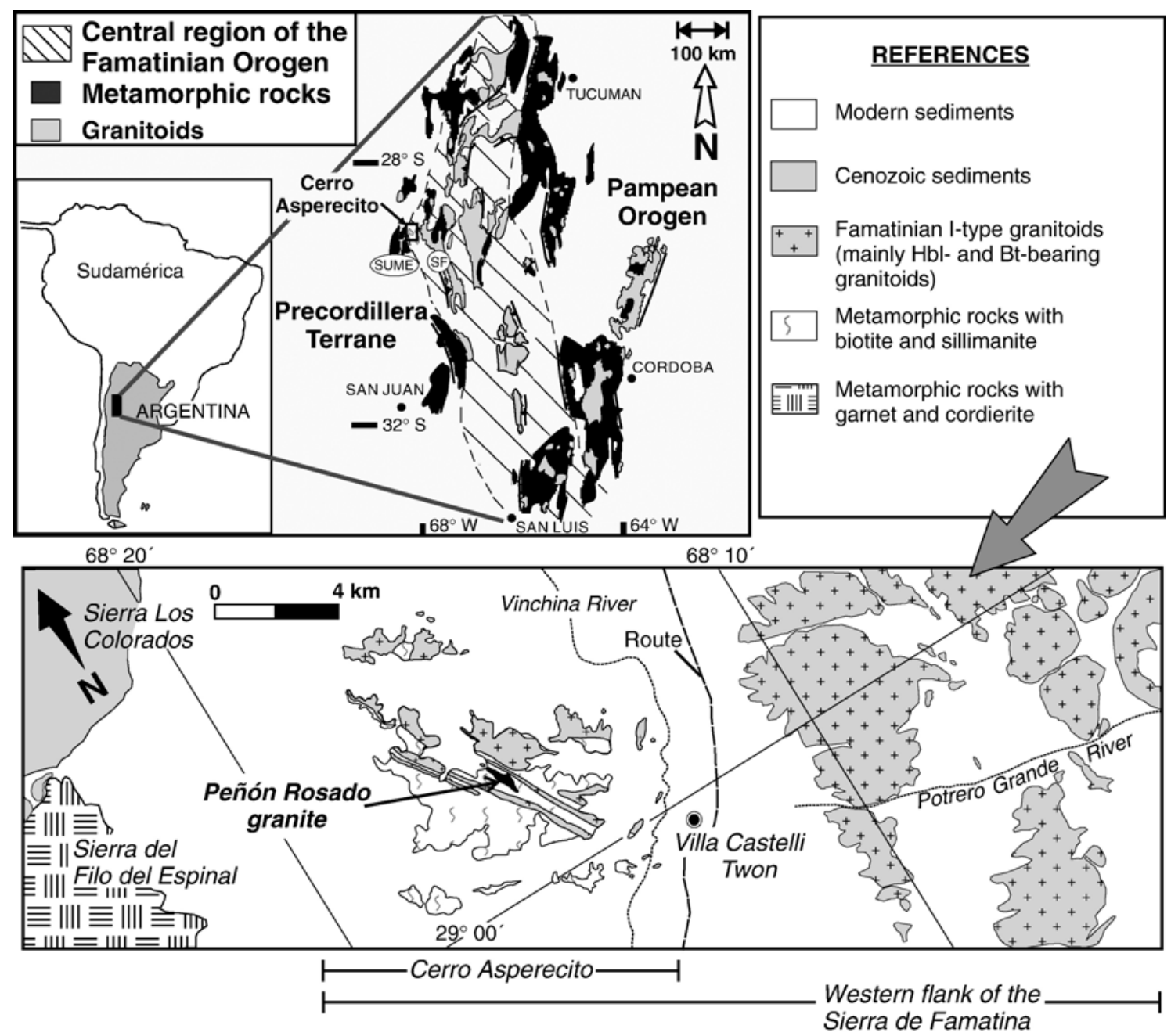

Fig. 1. Simplified geological map of Cerro Asperecito and the Peñón Rosado granite. Main inset shows location of the studied region in NW Argentina. SF=Sierra de Famatina. SUME=Sierras de Umango (west), Maz (south), and Filodel Espinal (north). 
Dahlquist et al., 2005a). This study focuses on Famatinian granitoids at Cerro Asperecito in the westernmost region of the Famatinian orogen, close to the hypothetical suture between two terranes resulting from Middle Ordovician accretion (Thomas and Astini, 1996; Dalziel, 1997; Rapela et al., 1998b; Casquet et al., 2001).

The dominant plutonic rocks in this region belong to a metaluminous suite $(95 \%$ of the granitic rocks at Cerro

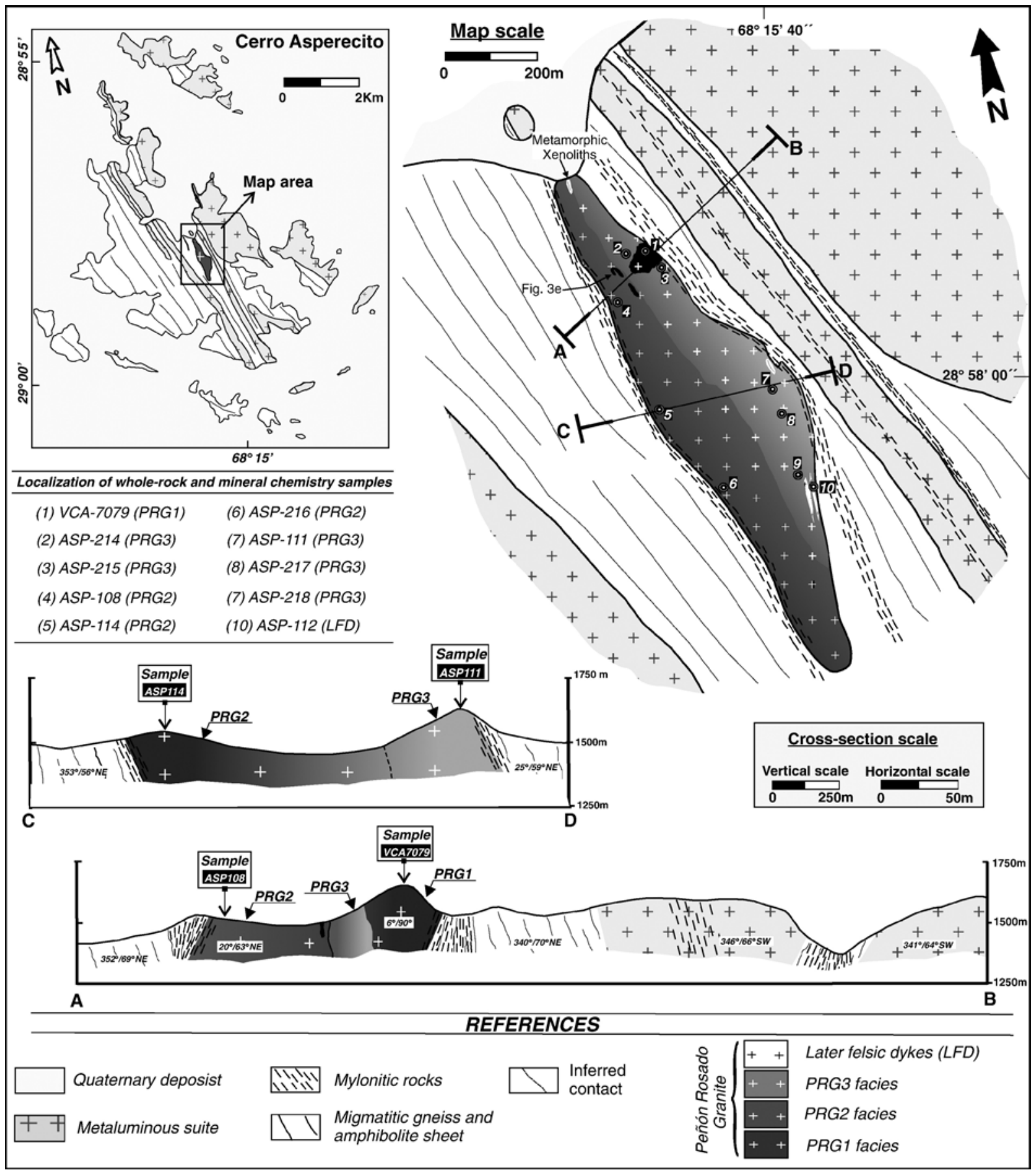

Fig. 2. Geological cross-section of the Peñón Rosado granite (PRG), showing the different lithological facies. The real size of the dykes as well as the real size of PRG1 housed in PRG2 have been magnified for its inclusion in the map. 
Asperecito, Fig. 2), which range in composition from hornblende-bearing gabbro $(10 \%)$ and tonalites-granodiorites $(80 \%)$ to monzogranite $(5 \%)$. They were emplaced in a high-grade migmatitic gneiss basement that includes biotite gneiss, biotite-sillimanite gneiss and $\sim 1.5 \mathrm{~m}$ wide amphibolite sheets (Fig. 2). The Peñón Rosado granite is a small elongated body $\left(0.25 \mathrm{~km}^{2}\right.$, Fig. 2) emplaced in the migmatitic gneisses.

The metaluminous tonalites and granodiorites are equigranular, medium-grained $(1.5 \mathrm{~cm})$, and white to grey in colour, typically with mafic microgranular enclaves. They are composed of $\mathrm{Mc}, \mathrm{Pl}, \mathrm{Bt}$, and $\mathrm{Hbl}$ and the accessory minerals are Ep, \pm Aln, Ttn, Ap, oxides, and $\mathrm{Zrn}$ (mineral abbreviations are taken from Kretz, 1983). The hornblende-bearing gabbro unit is equigranular, medium- to coarse-grained $(1.5 \mathrm{~cm}$ to $5.0 \mathrm{~cm})$, green-black in colour, and the magmatic association is $\mathrm{Pl}$, Hbl, Qtz and Bt. The monzogranite unit is equigranular, medium-grained $(1.5 \mathrm{~cm})$ pink to orange in colour and consists of Mc, Pl, Qtz, Bt and Ms. Initial ${ }^{87} \mathrm{Sr} /{ }^{86} \mathrm{Sr}$ ratios and $\varepsilon(\mathrm{Nd}){ }_{468}$ (average of three samples) are 0.70886 and -5.1 (Dahlquist and Galindo, 2004). It is suggested that the parental melt of the metaluminous suite was mainly derived by melting of meta-igneous rocks in the middle to lower crust, without asthenospheric mantle contamination, a common feature of the metaluminous Famatinian granitoids. Geochronological data indicate that major metaluminous suite was emplaced during the Middle Ordovician (468 Ma, Pankhurst et al., 2000), almost synchronously with the Peñón Rosado granite (469 Ma, this work) and in similar $P-T$ conditions $\left(T=763 \pm 30{ }^{\circ} \mathrm{C}, P=4.7 \pm 0.5 \mathrm{~kb}\right.$; Dahlquist et al., 2006 and this work).

\section{The Peñón Rosado granite: petrology, mineral chemistry and whole-rock geochemistry}

\subsection{Analytical methods}

Petrographic investigations were conducted on 25 samples of the Peñón Rosado granite. Whole-rock major and trace elements were determined for 10 representative samples of the granite and 1 felsic dyke using ICP and ICP-MS (following the procedure 4-lithoresearch code), at Activation Laboratories, Ontario, Canada (ACTLABS).

Mineral chemistry was determined using a JEOL Superprobe JXA-8900-M equipped with five crystal spectrometers at the Luis Brú Electron Microscopy Center, Complutense University, Madrid, Spain. Operating conditions were: acceleration voltage of $15 \mathrm{kV}$, probe current of $20 \mathrm{nA}$, with a beam diameter between 1 to $2 \mu \mathrm{m}$. Absolute abundances for each element were determined by comparison with standards (Jarosewich et al., 1980; McGuire et al., 1992). An on-line ZAF program was used.

$\mathrm{Rb}-\mathrm{Sr}$ and $\mathrm{Sm}-\mathrm{Nd}$ determinations of four samples were carried out at the Geochronology and Isotope Geochemistry Center of the Complutense University (Madrid, Spain). Isotopic analyses were made on an automated multicollector $\mathrm{VG}^{\circledR}$ SECTOR 54 mass spectrometer. Errors are quoted throughout as two standard deviations from measured or calculated values. Analytical uncertainties are estimated to be $0.01 \%$ for ${ }^{87} \mathrm{Sr} /{ }^{86} \mathrm{Sr}, 0.006 \%$ for ${ }^{143} \mathrm{Nd} /{ }^{144} \mathrm{Nd}, 1 \%$ for ${ }^{87} \mathrm{Rb} /{ }^{86} \mathrm{Sr}$, and $0.1 \%{ }^{147} \mathrm{Sm} /{ }^{144} \mathrm{Nd}$. Replicate analyses of the NBS$987 \mathrm{Sr}$-isotope standard yielded an average ${ }^{87} \mathrm{Sr} /{ }^{86} \mathrm{Sr}$ ratio of $0.710247 \pm 0.00003(n=524)$. Fifty six analyses of La Jolla Nd-standard over year gave a mean ${ }^{143} \mathrm{Nd} /{ }^{144} \mathrm{Nd}$ ratio of $0.511846 \pm 0.00003$.

\subsection{Field occurrence and macroscopic description}

The Peñón Rosado granite is emplaced parallel to $\sim \mathrm{N}-\mathrm{S}$ structural trends $\left(350^{\circ}-340^{\circ}\right)$ in the high-grade migmatitic gneiss terrane (Figs. 2 and $3 \mathrm{a}$ ), of which it contains large xenoliths (Fig. 3b). The metaluminous suite crops out on both sides of the granite and both contacts have a superimposed mylonitic foliation, which is also observed in the metamorphic basement $\left(\sim 350^{\circ}\right.$, Fig. 3c). The main dip of the metamorphic basement foliation is NE $\left(59^{\circ}\right.$ to $\left.69^{\circ}\right)$, although at the contacts this changes to SW with a higher angle $\left(81^{\circ}\right.$, Fig. 2$)$, suggesting that the dip variation is due to the differential distribution of the mylonitic event on two bodies with distinctive rheological properties, the granitic rocks being more rigid than the metamorphic rocks.

The Peñón Rosado granite is massive, but in some places exhibits mineral alignment defining a single mylonitic foliation. Generally, it is leucocratic to mesocratic, containing biotite and subordinate muscovite. Based on field, petrographic and geochemical data, three facies are recognised: PRG2 and PRG3 are dominant, whereas PRG1 is subordinate, forming a very small outcrop (Fig. 2). All facies of the Peñón Rosado granite are medium-grained $(0.5 \mathrm{~cm})$, inequigranular, and with uniformly distributed $1-$ to $2-\mathrm{cm}$ phenocrysts of garnet (Fig. 3d). A garnet count was carried out in the field using $400 \mathrm{~cm}^{2}$ grids (four per facies), revealing an average of 25 grains for PRG1, 21 grain for PRG2, and 23 grains for PRG3.

Thin late felsic dykes (50-60 $\mathrm{cm}$ width and 100 $150 \mathrm{~cm}$ length) of medium-grain size $(0.4 \mathrm{~cm})$ and with a structural trend of $3^{\circ} / 90^{\circ}$ are included in the PRG3 

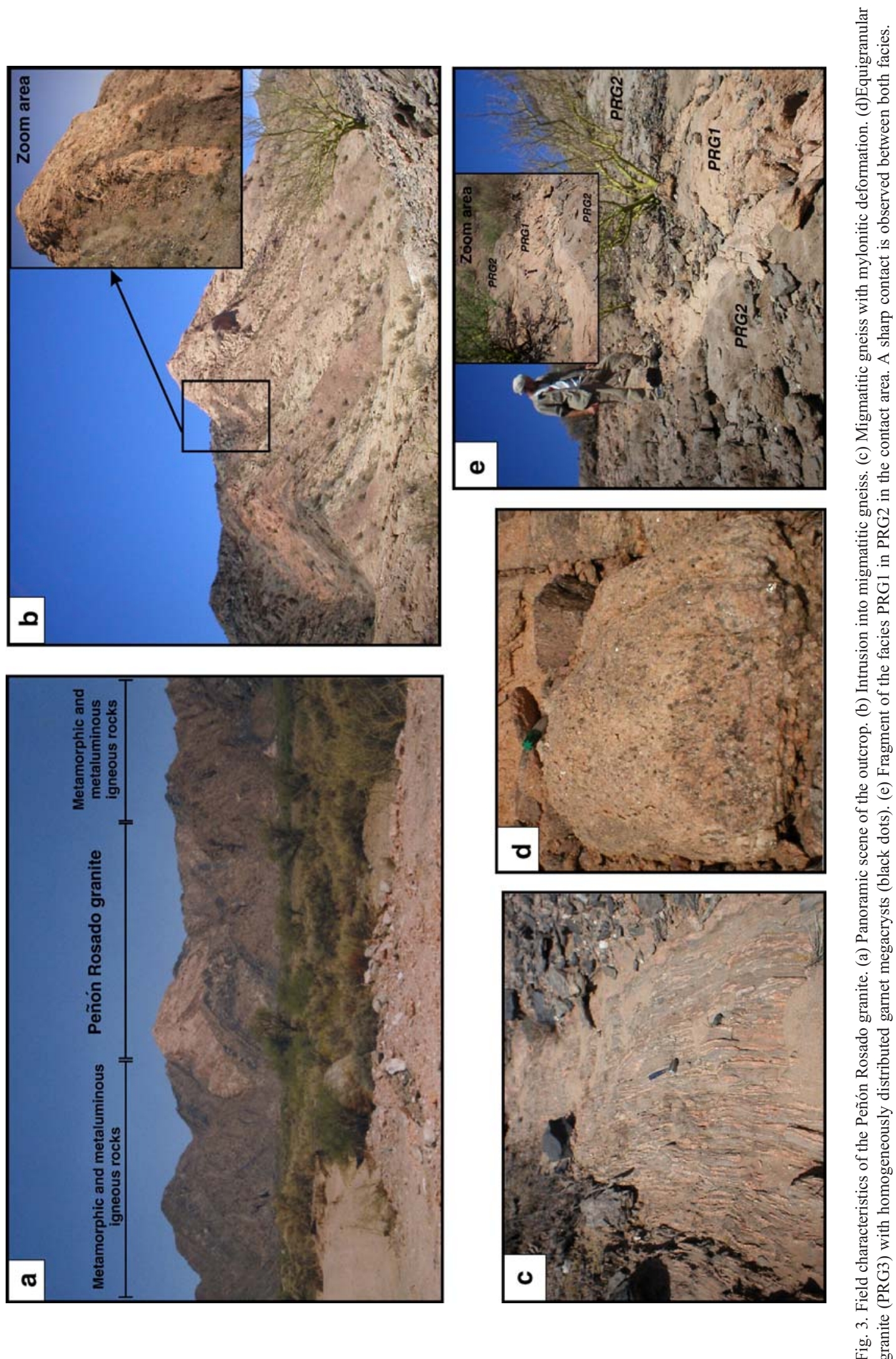

:

.00

을

오 뜬

豆

2

융 잉

苛垔

\& (2)

응

句

.

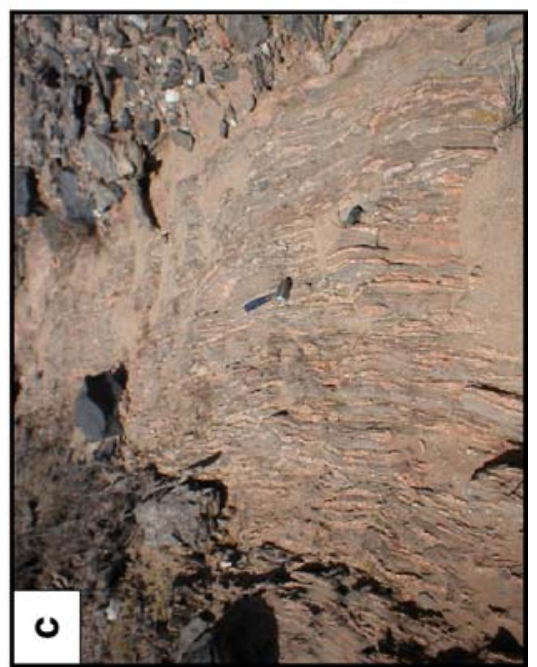

홍

()

莺

율

을

응 긍

Ð

氙

홍

킁

믈

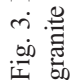


facies (Fig. 2) and consist of Pl, Qtz and Grt. The PRG1 facies is leucocratic, pink-to-orange, with very high $\mathrm{Pl}$ content $(64.37 \%)$ and subordinate $\mathrm{Grt}, \mathrm{Bt}$ and $\mathrm{Ms}$. PRG2 is mesocratic, grey, with Pl, Qtz, Grt and abundant Bt and Ms. PRG3 is leucocratic, pink-to-orange, with Pl, Grt, Bt, Ms, and abundant Kfs and Qtz. The presence of small rectangular to irregular fragments $(2.5 \mathrm{~m} \times 1.5 \mathrm{~m}$ or $5 \mathrm{~m} \times 1 \mathrm{~m})$ of the PRG1 facies in PRG2 (Fig. 3e), and the disruption of PRG1 by PRG2 in the contact area, suggest that the PRG2 facies was introduced when PRG1 was solid or partially molten.

\subsection{Petrography and mineral chemistry}

The magmatic assemblage for all three facies of the Peñón Rosado granite is $\mathrm{Pl}-\mathrm{Qtz}-\mathrm{Kfs}-\mathrm{Bt}-\mathrm{Ms}-\mathrm{Grt}$, with $\mathrm{Zrn}$ and oxides (mainly magnetite and hematite after magnetite) as accessory minerals. However, mineral proportions are very different in each facies (Table 1). Fluorapatite (with $\mathrm{F}=3.35 \%$ and $\mathrm{CaO}=54.32 \%$; analyses from one sample) and monazite were observed in PRG2. All the facies contain a very low percentage of oxides $(0.2-0.4 \%)$, which can even be absent in PRG1 and PRG3. Secondary epidote and biotite mantled by chlorite (after biotite) is common in PRG1. Analysed chlorites have high $\mathrm{MnO}$ contents (average of 5 samples $=2.41 \%$ ). Quartz forms anhedral crystals and in PRG3 occurs both in the framework of the rock and as inclusions in alkali feldspar. Undulose extinction is observed in all the quartz.

\subsubsection{Plagioclase}

Two main varieties of plagioclase were recognized in PRG1: (a) $\mathrm{Pl}_{\mathrm{a}}(3.2 \times 1.9 \mathrm{~mm})$, with patchy zoning, forming tabular and anhedral crystals and (b) $\mathrm{Pl}_{\mathrm{b}}$ $(1.7 \times 0.9 \mathrm{~mm})$, with continuous zoning, forming tabular, subhedral crystals with polysynthetic twinning. A finegrained $\mathrm{Pl}_{\mathrm{c}}(0.6 \times 0.4 \mathrm{~mm})$ occasionally appears in PRG1. The patchy zoning in $\mathrm{Pl}_{\mathrm{a}}$ is formed by intergrowth between a Na-rich phase $\left(\mathrm{Ab}_{69.2} \mathrm{An}_{29.1} \mathrm{Or}_{1.6}\right)$ and $\mathrm{Ca}$ rich phase $\left(\mathrm{Ab}_{66.5} \mathrm{An}_{32.3} \mathrm{Or}_{1.2}\right.$; Table $\left.2 \mathrm{a}\right)$. $\mathrm{Pl}_{\mathrm{b}}$ compositions range from $\mathrm{Ab}_{66.1} \mathrm{An}_{33.0} \mathrm{Or}_{0.9}$ in the core to $\mathrm{Ab}_{67.8}$ $\mathrm{An}_{31.3} \mathrm{Or}_{0.9}$ in the rim (Table 2a). Two varieties of plagioclase, were also recognized in $\mathrm{PRG} 2\left(\mathrm{Pl}_{\mathrm{a}}\right.$, $2.8 \times 1.9 \mathrm{~mm}$ and $\mathrm{Pl}_{\mathrm{b}}, 1.8 \times 1.1 \mathrm{~mm}$ ) with similar features to the $\mathrm{Pl}_{\mathrm{b}}$ in $\mathrm{PRG} 1$. The composition range is from $\mathrm{Ab}_{58.5}$ $\mathrm{An}_{39.8} \mathrm{Or}_{1.7}$ in the core to $\mathrm{Ab}_{64.2} \mathrm{An}_{34.2} \mathrm{Or}_{1.6}$ in the rim for $\mathrm{Pl}_{\mathrm{a}}$; and $\mathrm{Ab}_{52.1} \mathrm{An}_{46.4} \mathrm{Or}_{1.4}$ in the core to $\mathrm{Ab}_{62.3}$ $\mathrm{An}_{35.8} \mathrm{Or}_{1.9}$ in the rim for $\mathrm{Pl}_{\mathrm{b}}$ (Table 2a). The plagioclase in PRG3 facies occurs in two sizes, medium-grained ( $\mathrm{Pl}_{\mathrm{a}}$, $2.8 \times 1.3 \mathrm{~mm})$ and fine-grained $\left(\mathrm{Pl}_{\mathrm{b}}, 1.2 \times 0.6 \mathrm{~mm}\right)$. Both form tabular subhedral-anhedral crystals with polysynthetic twinning and continuous zonation. $\mathrm{Pl}_{\mathrm{a}}$ shows an oscillatory profile from $\mathrm{Ab}_{80.4} \mathrm{An}_{18.0} \mathrm{Or}_{1.60}$ to $\mathrm{Ab}_{82.2}$ $\mathrm{An}_{16.1} \mathrm{Or}_{1.70}$ (Table 2a).

\subsubsection{Alkali feldspar}

In PRG1 interstitial alkali feldspar (Mc) occasionally appears filling small cavities in deformed plagioclase crystals (curved twinning and fracture). The alkali feldspar in PRG2 occurs sparsely as individual grains of

Table 1

Modal and chemical classification of Peñón Rosado granite

\begin{tabular}{|c|c|c|c|c|}
\hline Igneous facies & PRG1 & PRG2 & PRG3 & LFD \\
\hline Representative samples & VCA-7079 $n=2$ & ASP-114 $n=1$ & ASP-111 $n=1$ & ASP-112 $n=1$ \\
\hline Total points & 1640 & 926 & 1027 & 934 \\
\hline Qtz & $24.9 \pm 4.6$ & 32.8 & 33.2 & 45.5 \\
\hline Kfs & $\operatorname{Tr}$ & 7.8 & 25.6 & - \\
\hline P1 & $64.2 \pm 3.0$ & 45.7 & 34.4 & 52.5 \\
\hline $\mathrm{Bt}$ & $5.4 \pm 0.7$ & 11.0 & 1.2 & 0.6 \\
\hline Ms & $2.2 \pm 0.1$ & 1.0 & 2.7 & 0.3 \\
\hline Grt & $1.8 \pm 0.1$ & 0.5 & 1.5 & 0.9 \\
\hline Ap & - & 0.2 & - & - \\
\hline Zrn & $0.3 \pm 0.1$ & 0.2 & 0.2 & - \\
\hline $\mathrm{Mnz}$ & - & 0.3 & - & - \\
\hline Mag & $0.3 \pm 0.1$ & 0.4 & 0.3 & 0.2 \\
\hline $\mathrm{Chl}+\mathrm{Ep}$ & $0.9 \pm 0.4$ & 0.1 & - & - \\
\hline Modal classification $Q A P^{\mathrm{a}}$ & Tonalite & Tonalite-granodiorite & Monzongranite & Tonalite \\
\hline$A b-A n-O r^{\mathrm{b}}$ & Trondhjemite & Tonalite-granodiorite & Granite & Trondhjemite \\
\hline
\end{tabular}

Nomenclature in the table: Abbreviation mineral taken from Kretz (1983). Abbreviations: PRG: Peñon Rosado granite; LFD: late felsic dyke; $\operatorname{Tr}=$ traces; $n=$ number of samples. Dashed line: absent mineral.

a QAP classification following Streckeisen (1976).

b Ab-An-Or classification following Barker (1979). Chemical data in Table 3. 
Table 2a

Representative compositions of plagioclases in Peñón Rosado granite from electron microprobe analyses

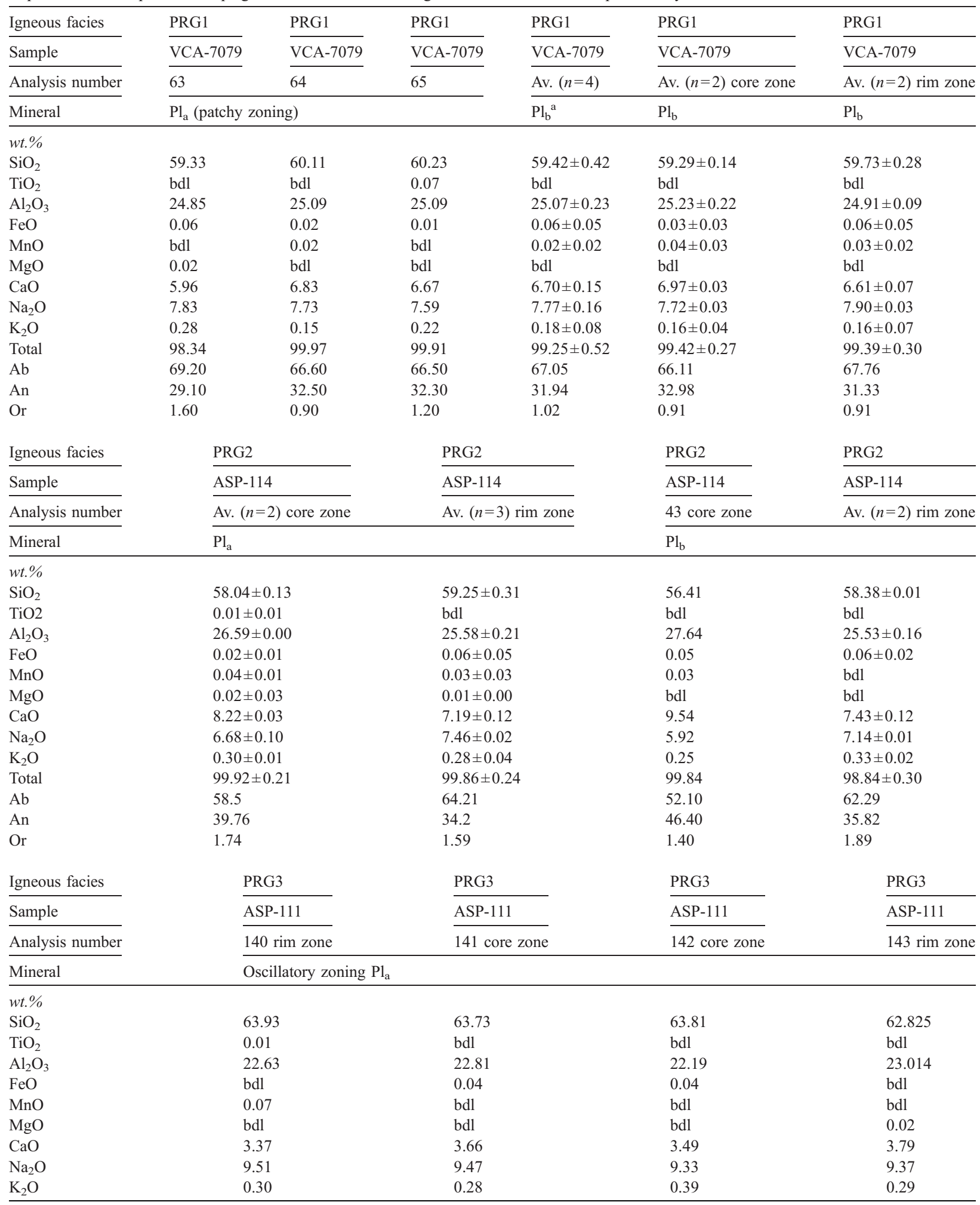


Table 2a (continued)

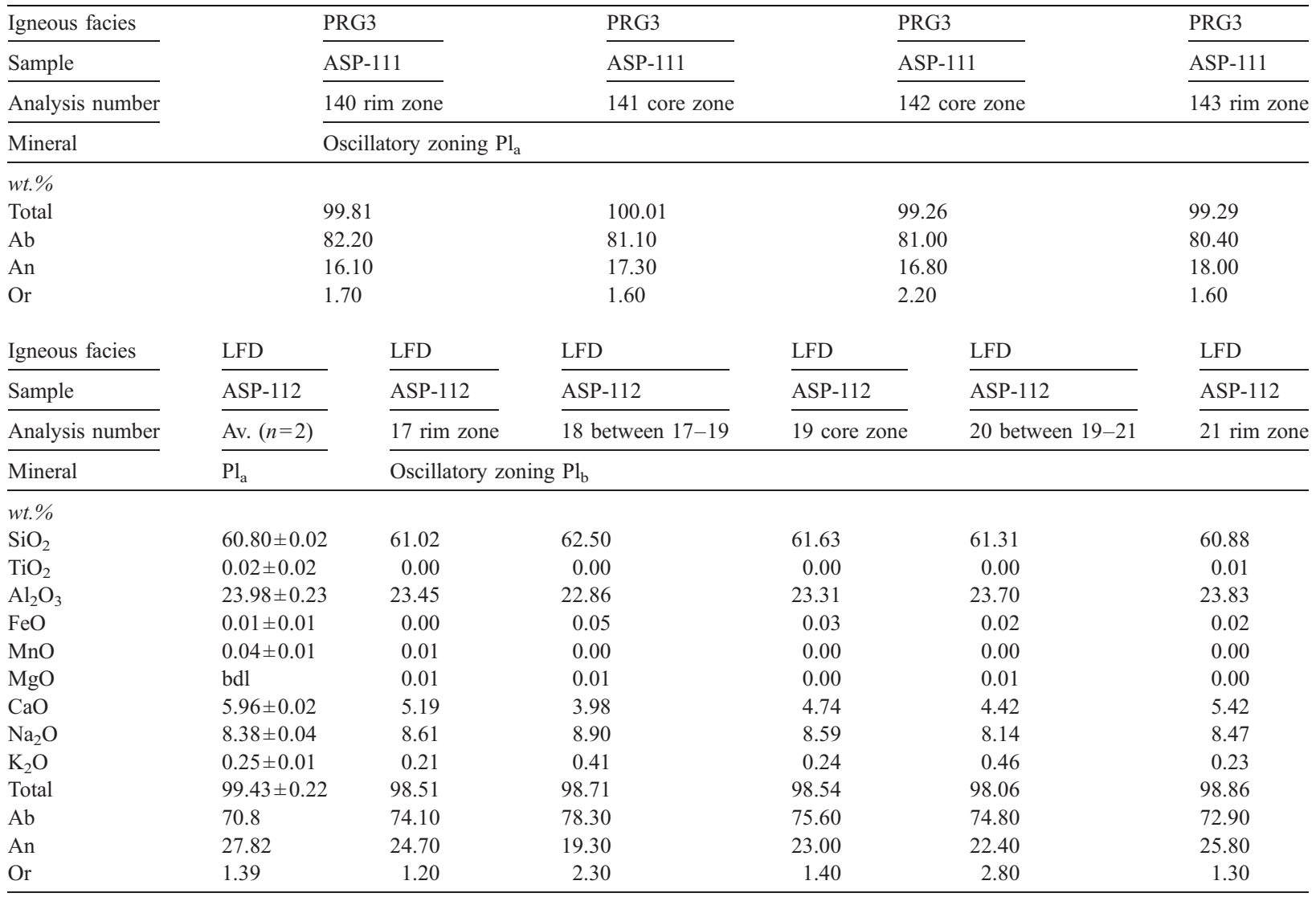

Nomenclature in the table: Total iron measured as FeO, structural formulae calculated following Richard (1995), mineral abbreviation are taken from Kretz (1983). Abbreviations: PRG=Peñón Rosado granite; bdl=below detection limit; Av. =average; $n=$ number of samples.

References as in Table 2a for the plagioclases in PRG1.

$\mathrm{LFD}=$ Late felsic dyke.

${ }^{\text {a }}$ Representative composition of plagioclase used in geothermobarometry and fractional crystallization model using major oxides, which result from the average between core and rim zone of the $\mathrm{Pl}_{\mathrm{b}}$ (explanation in Section 7).

orthoclase (representative composition in Table 2b). The lack of cross-hatched twinning and microperthite suggests crystallization in the upper solvus field, and a very low $\mathrm{Na}$ content in the magma during the crystallization of PRG2. Mc is abundant in PRG3 (Table 1), is coarse-to-medium-grained $\left(\mathrm{Mc}_{\mathrm{a}}, 5.1 \times 3.3 \mathrm{~mm}\right.$ to $2.6 \times 1.3 \mathrm{~mm}$ ), and forms rectangular subhedral-anhedral crystals, generally with perthitic texture and inclusions of Qtz-Pl-Ms. The medium-to-fine-grained $\mathrm{Mc}_{\mathrm{b}}(0.6 \times 0.3 \mathrm{~mm})$ is intergranular and without inclusions. A representative composition of $\mathrm{Mc}_{\mathrm{a}}$ is shown in Table 2b.

\subsubsection{Garnet}

Garnet is abundant in all facies of the Peñón Rosado granite and is present in most of the collected samples (Table 1). All garnets types have distinctive red cores, with hematite(?)-coated fractures and form hexagonal sections, some time irregular, euhedral to subhedral crystals without or few mineral inclusions such as chlorite (after biotite) and secondary muscovite. Fig. 4 shows that garnet compositions in the Peñon Rosado granite are similar to those in other peraluminous plutons and, in particular, to the magmatic garnets reported by du Bray (1988). In the PRG, the textural studies have revealed three garnet populations according to their sizes in PRG1: Grt $_{\mathrm{a}}(1.7-1.5 \mathrm{~mm}), \mathrm{Grt}_{\mathrm{b}}(1.3-$ $1.0 \mathrm{~mm})$ and $\mathrm{Grt}_{\mathrm{c}}(0.8-0.6 \mathrm{~mm})$; two garnet populations in PRG2: $\operatorname{Grt}_{\mathrm{a}}(2.3 \times 1.9 \mathrm{~mm}), \mathrm{Grt}_{\mathrm{b}}(1.7 \times 1.0 \mathrm{~mm})$, and a single garnet population in PRG3 $\left(\mathrm{Grt}_{\mathrm{a}}, 2.1 \times 2.2 \mathrm{~mm}\right)$. The analysed garnets in PRG are largely a solid solution of almandine-spessartine, which constitutes 81.32$88.53 \%$ of the total molecular composition (Table 2c). Pyrope, andradite, and grossular, and very rare or absent uvarovite, together make up the remainder. Detailed petrographic and electron microprobe studies revealed 
Table $2 b$

Representative compositions of alkali feldspar in Peñón Rosado granite from electron microprobe analyses

\begin{tabular}{|c|c|c|c|c|c|c|}
\hline Igneous facies & PRG2 & PRG2 & PRG3 & PRG3 & PRG3 & PRG3 \\
\hline Sample & ASP-114 & ASP-114 & ASP-111 & ASP-111 & ASP-111 & ASP-111 \\
\hline Analysis number & 47 & 50 & 2 rim zone & 3 central zone & 4 central zone & 5 rim zone \\
\hline Mineral & $\mathrm{Kfs}$ & Kfs & Kfs & & & \\
\hline \multicolumn{7}{|l|}{$w t . \%$} \\
\hline $\mathrm{SiO}_{2}$ & 64.16 & 63.87 & 64.08 & 64.30 & 63.32 & 63.86 \\
\hline $\mathrm{TiO}_{2}$ & 0.01 & bdl & 0.03 & bdl & 0.02 & 0.02 \\
\hline $\mathrm{Al}_{2} \mathrm{O}_{3}$ & 18.85 & 18.77 & 18.72 & 18.61 & 18.79 & 18.51 \\
\hline $\mathrm{FeO}$ & 0.02 & bdl & bdl & 0.04 & bdl & bdl \\
\hline $\mathrm{MnO}$ & 0.05 & bdl & bdl & bdl & 0.03 & bdl \\
\hline $\mathrm{MgO}$ & bdl & bdl & bdl & 0.03 & 0.01 & bdl \\
\hline $\mathrm{CaO}$ & 0.07 & 0.05 & 0.05 & 0.042 & 0.04 & 0.10 \\
\hline $\mathrm{Na}_{2} \mathrm{O}$ & 1.11 & 0.91 & 1.58 & 1.51 & 1.30 & 1.40 \\
\hline $\mathrm{K}_{2} \mathrm{O}$ & 15.37 & 15.25 & 15.80 & 15.47 & 15.84 & 15.59 \\
\hline Total & 99.64 & 98.85 & 100.31 & 100.08 & 99.41 & 99.52 \\
\hline $\mathrm{Ab}$ & 9.90 & 8.30 & 13.10 & 12.90 & 11.10 & 11.90 \\
\hline An & 0.30 & 0.30 & 0.20 & 0.20 & 0.20 & 0.50 \\
\hline Or & 89.80 & 91.50 & 86.60 & 86.90 & 88.70 & 87.60 \\
\hline
\end{tabular}

References as in Table 2a for the plagioclases in PRG1.

that all the garnet types in each facies have a similar zoning pattern and similar absolute oxides concentrations. Two garnets housed in the PRG1 were chosen for compositional mapping and zoning profiles (Fig. 5 and Table 2c). A spessartine component between 27.86 and $30.29 \%$ (average from 9 samples $=28.96 \%$ ) is represen- tative of the large unzoned homogenous central area, whereas the marginal rims typically have $34.69-43.50 \%$ (average from 8 samples $=39.18 \%$ ). The intermediate compositional zone has a spessartine range between 32.11 and $33.38 \%$ (average from 4 samples $=33.21 \%$ ). Thus, the profiles exhibited relatively Mn-poor central

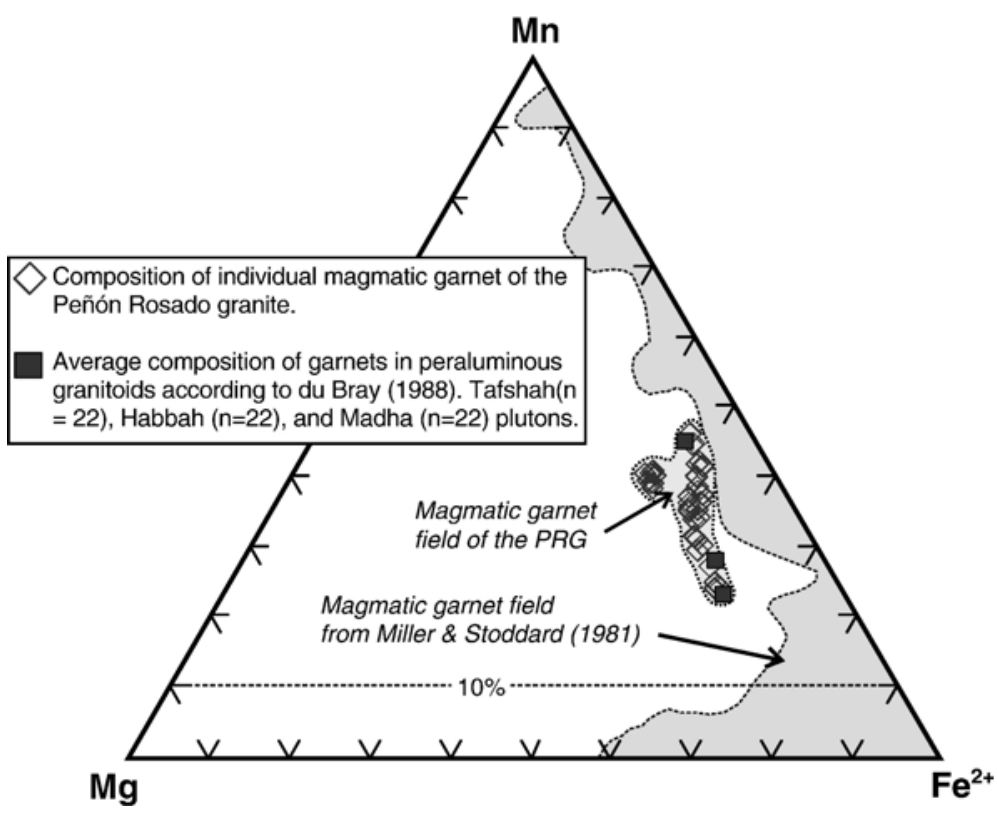

Fig. 4. Garnet compositions (Mn, Fe, and Mg) for the Peñón Rosado granite. The grey field is for garnet compositions from the compilation of Miller and Stoddard (1981) and garnet compositions in peraluminous granitoids are from du Bray (1988). The compilation of Miller and Stoddard (1981) reveals that an overwhelming majority of garnets found in granitoids contain $>10 \%$ spessartine component $(n=$ number of analyses). 
Table 2c

Representative compositions of garnet in Peñón Rosado granite from electron microprobe analyses

\begin{tabular}{|c|c|c|c|c|c|c|c|c|c|c|}
\hline \multirow{2}{*}{$\frac{\text { Igneous facies }}{\text { Sample }}$} & PRG1 & PRG1 & PRG1 & PRG1 & \multirow{2}{*}{$\begin{array}{l}\text { PRG1 } \\
\text { VCA- } \\
7079\end{array}$} & \multirow{2}{*}{$-\frac{\text { PRG1 }}{\text { VCA- }}=$} & \multirow{2}{*}{$\begin{array}{l}\text { PRG1 } \\
\text { VCA- } \\
7079\end{array}$} & PRG1 & \multirow{2}{*}{$\begin{array}{l}\text { PRG1 } \\
\text { VCA- } \\
7079\end{array}$} & \multirow{2}{*}{$\begin{array}{l}\text { PRG1 } \\
\text { VCA- } \\
7079\end{array}$} \\
\hline & VCA-7079 & VCA-7079 & VCA-7079 & $\begin{array}{l}\text { VCA- } \\
7079\end{array}$ & & & & $\begin{array}{l}\text { VCA- } \\
7079\end{array}$ & & \\
\hline $\begin{array}{l}\text { Analysis } \\
\text { number }\end{array}$ & $\begin{array}{l}\text { Av. }(n=7) \\
\mathrm{CZ}^{\mathrm{a}}\end{array}$ & $\begin{array}{l}\text { Av. }(n=2) \\
\text { ICZ }\end{array}$ & $\begin{array}{l}\text { Av. }(n=4) \\
\text { MRZ }\end{array}$ & $1 \mathrm{MRZ}$ & $2 \mathrm{MRZ}$ & $29 \mathrm{ICZ}$ & $3 \mathrm{RC}$ & $4 \mathrm{RC}$ & $6 \mathrm{MRZ}$ & $7 \mathrm{MRZ}$ \\
\hline Mineral & $\mathrm{Grt}_{\mathrm{a}}$ & & & & & Composit & on profile Grt & & & \\
\hline$w t . \%$ & & & & & & & & & & \\
\hline $\mathrm{SiO}_{2}$ & $37.58 \pm 0.17$ & $37.68 \pm 0.18$ & $37.12 \pm 0.14$ & 37.11 & 37.55 & 37.80 & 37.85 & 37.37 & 36.94 & 37.13 \\
\hline $\mathrm{TiO}_{2}$ & $0.09 \pm 0.09$ & bdl & $0.02 \pm 0.02$ & 0.02 & bld & bld & 0.02 & 0.23 & 0.06 & bdl \\
\hline $\mathrm{Al}_{2} \mathrm{O}_{3}$ & $21.16 \pm 0.26$ & $21.47 \pm 0.14$ & $21.5 \pm 0.18$ & 21.43 & 21.57 & 21.37 & 21.50 & 20.99 & 21.68 & 21.62 \\
\hline $\mathrm{FeO}$ & $23.96 \pm 0.58$ & $22.04 \pm 1.1$ & $20.72 \pm 0.87$ & 20.78 & 21.27 & 22.82 & 24.31 & 24.50 & 21.90 & 20.28 \\
\hline $\mathrm{CFeO}$ & 23.96 & 22.04 & 20.72 & 20.78 & 21.27 & 22.82 & 24.31 & 23.99 & 21.90 & 20.28 \\
\hline $\mathrm{CFe}_{2} \mathrm{O}_{3}$ & 0.00 & 0.00 & 0.00 & 0.00 & 0.00 & 0.00 & 0.00 & 0.57 & 0.00 & 0.00 \\
\hline $\mathrm{MnO}$ & $12.78 \pm 0.32$ & $14.3 \pm 0.01$ & $16.66 \pm 0.75$ & 17.00 & 14.29 & 14.31 & 12.75 & 12.37 & 15.57 & 16.82 \\
\hline $\mathrm{MgO}$ & $3.44 \pm 0.09$ & $2.71 \pm 0.34$ & $2.2 \pm 0.43$ & 1.98 & 2.47 & 2.94 & 3.31 & 3.51 & 2.80 & 1.81 \\
\hline $\mathrm{CaO}$ & $1.45 \pm 0.22$ & $1.28 \pm 0.07$ & $1.43 \pm 0.19$ & 1.43 & 1.23 & 1.33 & 1.40 & 1.61 & 1.20 & 1.66 \\
\hline $\mathrm{Na}_{2} \mathrm{O}$ & $0.02 \pm 0.02$ & $0.01 \pm 0.01$ & $0.01 \pm 0.01$ & 0.01 & bld & 0.03 & bld & 0.04 & 0.02 & 0.01 \\
\hline $\mathrm{K}_{2} \mathrm{O}$ & bdl & bdl & bdl & bld & bld & bld & bld & bld & bld & bld \\
\hline Total & 100.48 & 99.49 & 99.67 & 99.76 & 98.38 & 100.60 & 101.14 & 100.62 & 100.17 & 99.33 \\
\hline CTotal & 100.48 & 99.49 & 99.67 & 99.76 & 98.38 & 100.60 & 101.14 & 100.68 & 100.17 & 99.33 \\
\hline End-members cat & lculated followi & ing Deer et al. (1 & 1992) & & & & & & & \\
\hline Almandine & 53.32 & 51.24 & 47.78 & 47.91 & 50.97 & 51.48 & 54.14 & 53.46 & 49.51 & 47.52 \\
\hline Andradite & 0.00 & 0.00 & 0.00 & 0.00 & 0.00 & 0.00 & 0.00 & 1.55 & 0.00 & 0.00 \\
\hline Grossular & 4.13 & 3.81 & 4.22 & 4.22 & 3.77 & 3.85 & 3.98 & 3.03 & 3.49 & 4.97 \\
\hline Pyrope & 13.65 & 11.23 & 9.04 & 8.13 & 10.54 & 11.84 & 13.14 & 13.91 & 11.28 & 7.54 \\
\hline Spessartine & 28.80 & 33.67 & 38.91 & 40.00 & 34.69 & 32.69 & 28.75 & 27.86 & 35.65 & 39.91 \\
\hline Uvarovite & 0.00 & 0.00 & 0.00 & 0.00 & 0.02 & 0.00 & 0.00 & 0.00 & 0.00 & 0.00 \\
\hline Igneous facies & PRG1 & PRG1 & PRG1 & PR & & PRG1 & PRG1 & & PRG1 & PRG1 \\
\hline Sample & VCA-707 & VCA-7079 & VCA-7079 & & -7079 & VCA-7079 & VCA-707 & & VCA-7079 & VCA-7079 \\
\hline Analysis number & $8 \mathrm{MRZ}$ & $9 \mathrm{MRZ}$ & $15 \mathrm{ICZ}$ & 10 & & $11 \mathrm{RC}$ & $14 \mathrm{ICZ}$ & & $12 \mathrm{MRZ}$ & $13 \mathrm{MRZ}$ \\
\hline Mineral & Compositi & ion profile $\mathrm{Grt}_{\mathrm{b}}$ & & & & & & & & \\
\hline$w t . \%$ & & & & & & & & & & \\
\hline $\mathrm{SiO}_{2}$ & 36.94 & 37.26 & 37.83 & 37 & & 37.41 & 37.78 & & 37.89 & 37.41 \\
\hline $\mathrm{TiO}_{2}$ & 0.01 & bdl & 0.01 & bdl & & 0.08 & 0.01 & & 0.06 & bdl \\
\hline $\mathrm{Al}_{2} \mathrm{O}_{3}$ & 21.37 & 21.21 & 21.62 & 21 & & 21.52 & 21.40 & & 21.76 & 21.27 \\
\hline $\mathrm{FeO}$ & 19.72 & 22.20 & 23.29 & 23 & & 23.61 & 22.70 & & 22.01 & 19.17 \\
\hline $\mathrm{CFeO}$ & 19.72 & 22.20 & 23.29 & 23 & & 23.61 & 22.70 & & 22.01 & 19.17 \\
\hline $\mathrm{CFe}_{2} \mathrm{O}_{3}$ & 0.00 & 0.00 & 0.00 & 0.0 & & 0.00 & 0.00 & & 0.00 & 0.00 \\
\hline $\mathrm{MnO}$ & 18.10 & 15.40 & 14.32 & 12 & & 13.06 & 14.72 & & 16.06 & 18.46 \\
\hline $\mathrm{MgO}$ & 1.76 & 2.34 & 2.89 & 3.3 & & 3.35 & 2.76 & & 2.38 & 1.68 \\
\hline $\mathrm{CaO}$ & 1.40 & 1.67 & 1.74 & 1.3 & & 1.33 & 1.62 & & 1.50 & 1.61 \\
\hline $\mathrm{Na}_{2} \mathrm{O}$ & 0.01 & 0.01 & bdl & bdl & & 0.02 & 0.03 & & 0.02 & 0.02 \\
\hline $\mathrm{K}_{2} \mathrm{O}$ & bdl & bdl & bdl & bdl & & bdl & bdl & & bdl & bdl \\
\hline Total & 99.31 & 100.08 & 101.71 & & & 100.35 & 101.02 & & 101.59 & 99.61 \\
\hline CTotal & 99.31 & 100.08 & 101.71 & & & 100.35 & 101.02 & & 101.59 & 99.61 \\
\hline End-members cat & lculated followi & ing Deer et al. (1) & 1992) & & & & & & & \\
\hline Almandine & 45.84 & 50.30 & 51.55 & 53 & & 52.97 & 50.82 & & 49.49 & 44.61 \\
\hline Andradite & 0.00 & 0.00 & 0.00 & 0.0 & & 0.00 & 0.00 & & 0.00 & 0.00 \\
\hline Grossular & 4.18 & 4.83 & 4.93 & 3.7 & & 3.82 & 4.66 & & 4.32 & 4.80 \\
\hline Pyrope & 7.30 & 9.43 & 11.41 & 13 & & 13.40 & 11.01 & & 9.53 & 6.98 \\
\hline Spessartine & 42.63 & 35.34 & 32.11 & 29. & & 29.68 & 33.38 & & 36.58 & 43.50 \\
\hline Uvarovite & 0.00 & 0.03 & 0.00 & 0.0 & & 0.00 & 0.00 & & 0.00 & 0.00 \\
\hline
\end{tabular}


Table 2c (continued)

\begin{tabular}{|c|c|c|c|c|c|c|c|}
\hline Igneous facies & PRG1 & PRG1 & PRG2 & PRG2 & PRG3 & LFD & LFD \\
\hline Sample & VCA-7079 & VCA-7079 & ASP-114 & ASP-114 & ASP-111 & ASP-112 & ASP-112 \\
\hline Analysis number & Av. $(n=3) \mathrm{CZ}$ & Av. $(n=2) \mathrm{RZ}$ & Av. $(n=3) \mathrm{CZ}$ & $55 \mathrm{RZ}$ & Av. $(n=9)$ CRZ & Av. $(n=3) \mathrm{CZ}$ & Av. $(n=2) \mathrm{RZ}$ \\
\hline Mineral & $\mathrm{Grt}_{\mathrm{c}}$ & & $\mathrm{Grt}_{\mathrm{a}}$ & & Grt & Grt & \\
\hline \multicolumn{8}{|l|}{$w t . \%$} \\
\hline $\mathrm{SiO}_{2}$ & $37.24 \pm 0.12$ & $37.21 \pm 0.33$ & $37.65 \pm 0.13$ & 38.05 & $37.21 \pm 0.34$ & $37.25 \pm 0.10$ & $37.04 \pm 0.12$ \\
\hline $\mathrm{TiO}_{2}$ & bdl & $0.15 \pm 0.05$ & $0.05 \pm 0.04$ & 0.02 & $0.07 \pm 0.04$ & $0.05 \pm 0.07$ & $0.02 \pm 0.02$ \\
\hline $\mathrm{Al}_{2} \mathrm{O}_{3}$ & $21.22 \pm 0.30$ & $21.24 \pm 0.15$ & $21.56 \pm 0.19$ & 21.88 & $21.25 \pm 0.36$ & $21.47 \pm 0.24$ & $21.53 \pm 0.00$ \\
\hline $\mathrm{FeO}$ & $23.26 \pm 0.15$ & $19.85 \pm 0.32$ & $26.12 \pm 0.11$ & 25.50 & $19.60 \pm 0.36$ & $22.52 \pm 0.47$ & $21.13 \pm 0.06$ \\
\hline $\mathrm{CFeO}$ & $23.26 \pm 0.15$ & $19.85 \pm 0.32$ & $23.12 \pm 0.11$ & 25.50 & $19.49 \pm 0.32$ & $22.42 \pm 0.32$ & $21.13 \pm 0.06$ \\
\hline $\mathrm{CFe}_{2} \mathrm{O}_{3}$ & 0.00 & 0.00 & 0.00 & 0.00 & $0.18 \pm 0.28$ & $0.12 \pm 0.16$ & 0.00 \\
\hline $\mathrm{MnO}$ & $13.43 \pm 0.18$ & $17.60 \pm 0.40$ & $10.17 \pm 0.20$ & 11.61 & $16.93 \pm 0.32$ & $14.52 \pm 0.28$ & $16.56 \pm 0.26$ \\
\hline $\mathrm{MgO}$ & $2.81 \pm 0.15$ & $1.61 \pm 0.15$ & $3.55 \pm 0.10$ & 3.39 & $3.66 \pm 0.16$ & $3.00 \pm 0.06$ & $2.04 \pm 0.17$ \\
\hline $\mathrm{CaO}$ & $1.42 \pm 0.15$ & $1.57 \pm 0.06$ & $1.39 \pm 0.03$ & 1.25 & $0.70 \pm 0.10$ & $1.16 \pm 0.07$ & $1.14 \pm 0.06$ \\
\hline $\mathrm{Na}_{2} \mathrm{O}$ & $0.01 \pm 0.01$ & bdl & $0.02 \pm 0.01$ & 0.02 & $0.03 \pm 0.02$ & $0.03 \pm 0.03$ & 0.00 \\
\hline $\mathrm{K}_{2} \mathrm{O}$ & bdl & bdl & bdl & 0.01 & 0.00 & $0.01 \pm 0.01$ & 0.00 \\
\hline Total & $99.40 \pm 0.49$ & $98.98 \pm 0.53$ & $100.54 \pm 0.13$ & 101.76 & $99.53 \pm 0.42$ & $100.00 \pm 0.26$ & $99.44 \pm 0.06$ \\
\hline CTotal & $99.40 \pm 0.49$ & $98.98 \pm 0.53$ & $100.54 \pm 0.13$ & 101.76 & $99.55 \pm 0.41$ & $100.02 \pm 0.29$ & $99.44 \pm 0.06$ \\
\hline \multicolumn{8}{|c|}{ End-members calculated following Deer et al. (1992) } \\
\hline Almandine & 53.21 & 46.64 & 58.60 & 56.74 & 44.2 & 50.84 & 49.10 \\
\hline Andradite & 0.00 & 0.00 & 0.00 & 0.00 & 0.49 & 0.25 & 0.00 \\
\hline Grossular & 4.16 & 4.73 & 4.00 & 3.55 & 1.52 & 3.13 & 3.40 \\
\hline Pyrope & 11.46 & 6.74 & 14.20 & 13.46 & 14.79 & 12.16 & 8.50 \\
\hline Spessartine & 31.12 & 41.89 & 23.11 & 26.16 & 38.82 & 33.45 & 39.0 \\
\hline Uvarovite & 0.00 & 0.00 & 0.00 & 0.00 & 0.00 & 0.00 & 0.00 \\
\hline
\end{tabular}

References as in Table 2a for the plagioclases in PRG1. Total iron measured as FeO; $\mathrm{Fe}^{3+}$ calculated following Droop (1987); C=calculated. $\mathrm{CZ}=$ central zone; $\mathrm{IRZ}=$ intermediate compositional zone; $\mathrm{MRZ}=$ marginal rim zone.

Averaged samples in: $\mathrm{CZ}=3,4,30,31,32,33,34 ; \mathrm{ICZ}=29,2$; $\mathrm{MRZ}=1,6,7,35$. All samples in Fig. 5.

References as in Table 2a for the plagioclases in PRG1. Total iron measured as FeO; $\mathrm{Fe}^{3+}$ calculated following Droop (1987); C $=$ calculated. $\mathrm{LFD}=$ late felsic dyke. $\mathrm{CZ}=$ central zone; $\mathrm{CRZ}=$ central-rim zone; $\mathrm{RZ}=$ rim zone.

${ }^{a}$ Representative composition of garnet used in geothermobarometry and fractional crystallization model using major oxides, which result from the average of the central zone (explanation in Section 7).

zones and relatively Mn-rich marginal rims zones, constituting a "spessartine inverse bell-shaped profile" (Fig. 5). In addition, $\mathrm{Mn}$ vs. $\mathrm{Fe}^{2+}+\mathrm{Mg}$ shows inverse correlation from marginal rim to central zone (Table 2c). The MnO content in the PRG2 garnets is lower than in PRG1 garnets but the $\mathrm{FeO}$ content is slightly higher. The characteristic zoning pattern exhibits a relatively Mnpoor central zone and a relatively Mn-rich rim zone, but with narrow composition variation (Table $2 \mathrm{~d}$ ), constituting a "smooth spessartine inverse bell-shaped profile". The PRG3 garnets have the highest MnO contents of any in the pluton. These garnets have relatively homogeneous spessartine content, with very narrow compositional variation (from spessartine $37.49 \%$ in the core to $39.72 \%$ in the rim, Table $2 \mathrm{~d}$ ), and are thus essentially unzoned.

\subsubsection{Dark micas}

The black micas in PRG1 and PRG2 occur in two sizes, medium-grained $\left(\mathrm{Bt}_{\mathrm{a}}, 1.4 \times 0.6 \mathrm{~mm}\right)$ and fine-grained $\left(\mathrm{Bt}_{\mathrm{b}}\right.$,
$0.5 \times 0.3 \mathrm{~mm}$ ), whereas the biotites in PRG3 are finegrained $(0.3 \times 0.2 \mathrm{~mm})$. All form tabular and irregular sections, are subhedral, and have light to dark brown pleochroism. Oxides, Ap and $\mathrm{Zrn}$ occur as inclusions in the PRG1 and PRG2 black micas, whereas zircon inclusions were observed in PRG3. The PRG1 black micas are commonly chloritized. In terms of $\mathrm{Al}^{\mathrm{IV}}$ vs. $\mathrm{Fe}^{2+} /$ $\left(\mathrm{Fe}^{2+}+\mathrm{Mg}\right)$ the black micas of the Peñon Rosado granite are classified as biotites with high siderophyllite-eastonite contents (Table 2d). The biotites in PRG3 have a similar composition to those in PRG1 and PRG2, although the $\mathrm{Fe}^{2+} /\left(\mathrm{Fe}^{2+}+\mathrm{Mg}\right)$ ratios are slightly lower (Table $2 \mathrm{~d}$ ).

The biotites of all facies have consistently high $\mathrm{Al}^{\mathrm{IV}}$ (mean 2.48 to 2.64 atom/formula unit) together with high $\mathrm{MnO}$ contents (e.g., $0.85 \%$ in the PRG1 facies, Table 2d), as found by Miller and Stoddard (1981) for biotite in garnet-bearing granite. Biotites with high $\mathrm{Al}^{\mathrm{IV}}$ seem to be characteristic of peraluminous granites (e.g., Dahlquist et al., 2005b; Clarke et al., 2005) where they coexist with aluminous minerals (Table 2d). 

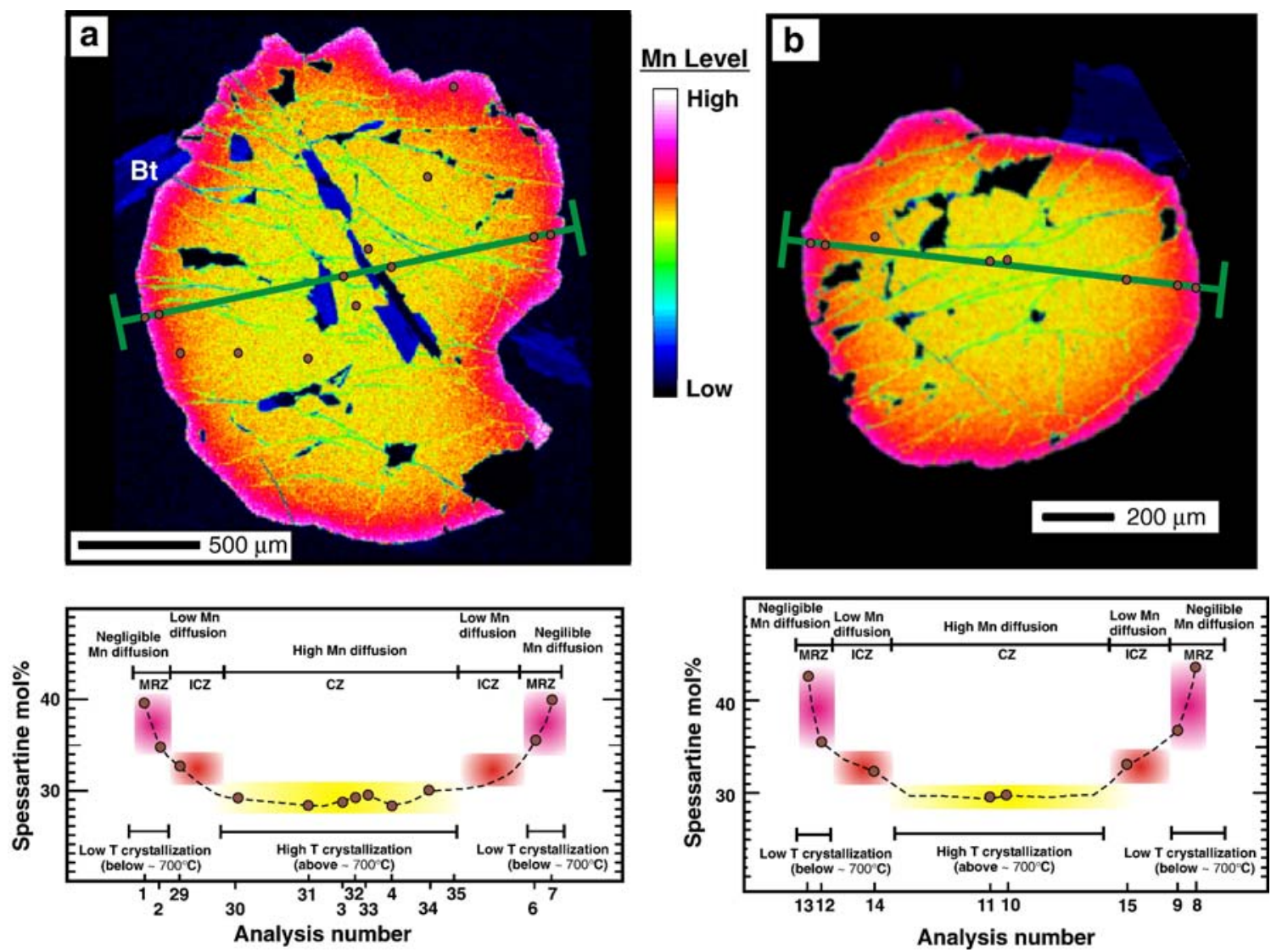

Fig. 5. X-ray compositional maps and zoning profiles for spessartine content from sample VCA-7079 (PRG1 facies) using electron microprobe. In general, the spessartine content follows an inverse bell-shaped profile. There is a large homogenous central zone (spessartine average $=28.96 \%$ ), an intermediate compositional zone (spessartine average $=33.21 \%$ ) and $\mathrm{Mn}$ enrichment of marginal rims ( spessartine average $=39.18 \%$ ). Orientations of the compositional profiles are indicated on the garnet. $\mathrm{CZ}=$ central zone, $\mathrm{ICZ}=$ intermediate compositional zone, and $\mathrm{MRZ}=$ marginal rim zone. Data in Table $2 \mathrm{c}$.

\subsubsection{White micas}

White mica is the other sheet silicate present. Care was taken to determine whether it is of primary or secondary origin, since primary white mica is widely held to be an indicator of peraluminous magmas (Speer, 1984). Petrographic observations using the criteria of Miller et al. (1981) suggest that both types are present. Chemical analyses were made of presumed primary white micas, which fall in the appropriate field of the $\mathrm{Mg}-\mathrm{Ti}-\mathrm{Na}$ diagram (Fig. 6) according to division established by Miller et al. (1981). They are also distinctively Fe-rich, similar to those in typical S-type granitoids of the Famatinian orogen (Table 2e) and those reported by Clarke et al. (2005) as coexisting with aluminous minerals. Thus, both textural and chemical evidence indicate a primary origin for some white micas of the Peñón Rosado granite.

\subsubsection{Late felsic dykes}

The magmatic association here is $\mathrm{Pl}-\mathrm{Qtz}-\mathrm{Grt}$ with $\mathrm{Bt}-\mathrm{Ms}-\mathrm{Zrn}$-oxides as accessory minerals. Plagioclase is medium-grained, forms tabular sections, and is subhedral or occasionally anhedral, with Qtz-Bt-oxides as inclusions. Polysynthetic twinning and both normal and oscillatory optical zoning are observed, with occasional patchy zoning. Two plagioclases were analysed, one with continuous zoning $\left(\mathrm{Pl}_{\mathrm{a}}, 3.9 \times 2.7 \mathrm{~mm}\right)$, and one with oscillatory zoning $\left(\mathrm{Pl}_{\mathrm{b}}, 1.3 \times 0.7 \mathrm{~mm}\right)$. The $\mathrm{Pl}_{\mathrm{a}}$ composition (average from two analyses) is $\mathrm{Ab}_{70.8}$ $\mathrm{An}_{27.9} \mathrm{Or}_{1.3}$ and the $\mathrm{Pl}_{\mathrm{b}}$ reveals oscillatory zoning with a composition range between $\mathrm{Ab}_{72.9} \mathrm{An}_{25.8} \mathrm{Or}_{1.3}$ and $\mathrm{Ab}_{78.3} \mathrm{An}_{19.3} \mathrm{Or}_{2.3}$ (Table 2a). The garnet $(1.9 \times 1.7 \mathrm{~mm})$ forms subhedral-euhedral hexagonal sections. The solid solution almandine-spessartine, constitutes 83.80 to $88.66 \%$ of the total molecular composition (Table 2c); pyrope, andradite and grossular make up the remainder. $\mathrm{MnO}$ content is high and the characteristic zoning pattern exhibits a relatively Mn-poor core and a relatively Mn-rich rim, constituting clearly a "spessartine inverse bell-shaped profile". Biotite and muscovite are sparse: the biotites are mantled by chlorite and the analysis 
Table $2 \mathrm{~d}$

Representative compositions of dark micas in Peñón Rosado granite from electron microprobe analyses and structural formulae

\begin{tabular}{|c|c|c|c|c|c|c|}
\hline \multirow{2}{*}{$\frac{\text { Igneous unit }}{\text { Igneous facies }}$} & \multicolumn{4}{|l|}{ PRG } & \multirow{2}{*}{$\frac{\mathrm{TG}^{\mathrm{a}}}{\text { Average }}$} & \multirow{2}{*}{$\frac{\mathrm{AG}^{\mathrm{b}}}{\text { Average }}$} \\
\hline & PRG1 & PRG2 & PRG3 & LFD & & \\
\hline Sample/s & VCA-7079 & ASP-114 & ASP-111 & ASP-112 & TUA-246, 49 & Plutonic rocks \\
\hline Analysis number & Av. $(n=4)$ & Av. $(n=6)$ & Av. $(n=8)$ & Av. $(n=2)$ & Av. $(n=6)$ & Av. $(n=52)$ \\
\hline Mineral & $\mathrm{Bt}^{\mathrm{c}}$ & $\mathrm{Bt}$ & $\mathrm{Bt}$ & $\mathrm{Bt}^{\mathrm{d}}$ & $\mathrm{Bt}$ & $\mathrm{Bt}$ \\
\hline \multicolumn{7}{|l|}{$w t . \%$} \\
\hline $\mathrm{SiO}_{2}$ & $35.76 \pm 0.27$ & $35.11 \pm 0.50$ & $35.53 \pm 0.45$ & $34.36 \pm 0.10$ & $34.77 \pm 0.73$ & $34.51 \pm 0.63$ \\
\hline $\mathrm{TiO}_{2}$ & $2.30 \pm 0.07$ & $2.59 \pm 0.31$ & $2.29 \pm 0.13$ & $0.82 \pm 0.04$ & $2.63 \pm 0.32$ & $2.55 \pm 0.53$ \\
\hline $\mathrm{Al}_{2} \mathrm{O}_{3}$ & $17.53 \pm 0.30$ & $19.32 \pm 0.19$ & $18.99 \pm 0.34$ & $18.69 \pm 0.11$ & $18.93 \pm 1.06$ & $19.94 \pm 0.83$ \\
\hline $\mathrm{FeO}$ & $19.39 \pm 0.36$ & $18.92 \pm 0.41$ & $15.94 \pm 0.27$ & $15.87 \pm 0.00$ & $17.38 \pm 0.71$ & $22.65 \pm 1.50$ \\
\hline $\mathrm{MnO}$ & $0.85 \pm 0.16$ & $0.44 \pm 0.19$ & $0.72 \pm 0.06$ & $1.00 \pm 0.07$ & $0.94 \pm 0.90$ & $0.40 \pm 0.24$ \\
\hline $\mathrm{MgO}$ & $8.94 \pm 0.11$ & $8.86 \pm 0.41$ & $10.63 \pm 0.29$ & $12.79 \pm 0.10$ & $10.33 \pm 0.56$ & $5.75 \pm 1.68$ \\
\hline $\mathrm{CaO}$ & $0.02 \pm 0.02$ & $0.02 \pm 0.02$ & $0.02 \pm 0.03$ & $0.18 \pm 0.02$ & $0.04 \pm 0.03$ & $0.01 \pm 0.01$ \\
\hline $\mathrm{Na}_{2} \mathrm{O}$ & $0.09 \pm 0.04$ & $0.05 \pm 0.02$ & $0.09 \pm 0.02$ & $0.07 \pm 0.01$ & $0.19 \pm 0.03$ & $0.14 \pm 0.06$ \\
\hline $\mathrm{K}_{2} \mathrm{O}$ & $9.65 \pm 0.19$ & $9.74 \pm 0.10$ & $10.30 \pm 0.50$ & $6.16 \pm 0.12$ & $8.90 \pm 0.59$ & $9.40 \pm 0.22$ \\
\hline $\mathrm{F}$ & $0.32 \pm 0.16$ & $0.11 \pm 0.07$ & $0.50 \pm 0.05$ & $0.09 \pm 0.02$ & $0.17 \pm 0.03$ & $1.17 \pm 0.46$ \\
\hline $\mathrm{Cl}$ & $0.01 \pm 0.00$ & $0.02 \pm 0.01$ & $0.04 \pm 0.01$ & $0.01 \pm 0.01$ & bld & nd \\
\hline Total & $94.90 \pm 0.66$ & $95.17 \pm 0.55$ & $95.07 \pm 0.63$ & $90.08 \pm 0.03$ & $94.38 \pm 1.24$ & $96.42 \pm 0.63$ \\
\hline O_F_Cl & $0.14 \pm 0.07$ & $0.05 \pm 0.03$ & $0.22 \pm 0.02$ & $0.04 \pm 0.01$ & $0.07 \pm 0.06$ & 0.49 \\
\hline CTotal & $94.76 \pm 0.61$ & $95.12 \pm 0.54$ & $94.85 \pm 0.62$ & $90.04 \pm 0.02$ & $94.31 \pm 1.26$ & 95.93 \\
\hline \multicolumn{7}{|c|}{ Structural formulae calculated on basis $22 O$} \\
\hline $\mathrm{Si}$ & 5.52 & 5.37 & 5.41 & 5.38 & $5.32 \pm 0.04$ & 5.35 \\
\hline $\mathrm{Al}^{\mathrm{IV}}$ & 2.48 & 2.64 & 2.59 & 2.62 & $2.68 \pm 0.04$ & 2.65 \\
\hline Sum-T & 8.00 & 8.00 & 8.00 & 8.00 & $8.00 \pm 0.00$ & 8.00 \\
\hline $\mathrm{Al}^{\mathrm{VI}}$ & 0.71 & 0.84 & 0.81 & 0.83 & $0.74 \pm 0.22$ & 0.98 \\
\hline $\mathrm{Ti}$ & 0.27 & 0.30 & 0.26 & 0.10 & $0.30 \pm 0.04$ & 0.30 \\
\hline $\mathrm{Fe}^{2+}$ & 2.50 & 2.42 & 2.03 & 2.08 & $2.23 \pm 0.11$ & 2.92 \\
\hline $\mathrm{Mn}$ & 0.11 & 0.06 & 0.09 & 0.13 & $0.12 \pm 0.13$ & 0.05 \\
\hline $\mathrm{Mg}$ & 2.06 & 2.02 & 2.41 & 2.99 & $2.36 \pm 0.12$ & 1.33 \\
\hline Sum-B & 5.65 & 5.64 & 5.60 & 6.13 & $5.74 \pm 0.07$ & 5.58 \\
\hline $\mathrm{Ca}$ & 0.00 & 0.00 & 0.00 & 0.03 & $0.01 \pm 0.00$ & 0.00 \\
\hline $\mathrm{Na}$ & 0.03 & 0.02 & 0.03 & 0.02 & $0.06 \pm 0.0$ & 0.04 \\
\hline K & 1.91 & 1.90 & 2.00 & 1.23 & $1.74 \pm 0.11$ & 1.86 \\
\hline Sum-A & 1.94 & 1.92 & 2.03 & 1.28 & $1.80 \pm 0.11$ & 1.90 \\
\hline $\mathrm{CF}$ & 0.31 & 0.11 & 0.48 & 0.09 & $0.16 \pm 0.13$ & 1.15 \\
\hline $\mathrm{CCl}$ & 0.00 & 0.01 & 0.02 & 0.00 & 0.00 & 0.00 \\
\hline $\mathrm{Fe}^{2+} /\left(\mathrm{Fe}^{2+}+\mathrm{Mg}\right)$ & 0.55 & 0.55 & 0.46 & 0.41 & $0.49 \pm 0.02$ & 0.69 \\
\hline
\end{tabular}

References as in Table 2a for the plagioclases in PRG1. $\mathrm{C}=$ calculated. $\mathrm{LFD}=$ late felsic dyke. $\mathrm{nd}=$ not determined.

${ }^{a}$ Biotites in Tuaní Granite unit (cordierite-bearing granitoids), database from Dahlquist et al. (2005b).

${ }^{\mathrm{b}}$ Biotites in andalusite-bearing granitoids, database from Clarke et al. (2005).

${ }^{c}$ Representative composition of biotite used in geothermobarometry and fractional crystallization model using major oxides, which result from the average of 4 samples (explanation in Section 7).

d Chloritized biotite.

reveals that the original composition has been partially modified (Table 2d). Quartz is abundant, rectangular to irregular and subhedral-anhedral.

\subsection{Whole-rock geochemistry}

\subsubsection{Major elements}

The Peñón Rosado granite has an average aluminium saturation index of 1.12 (Table 3) and is classified as a slightly peraluminous suite according to the nomencla- ture of Chappell and White (1992). It displays a distinct chemical trend compared with (a) the metaluminous granitoids of Cerro Asperecito (Fig. 2), (b) the typical Famatinian metaluminous granitoids of the Sierra de Chepes, (c) the Boggy Plain metaluminous supersuite, an extensive $(500 \mathrm{~km})$ and well-known belt of I-type granitoids in the central Lachlan Fold Belt of SE Australia, whose parental magma was derived by reworking of pre-existing crust in a similar way to that of the Famatinian granitoids (Wyborn et al., 1987; Pankhurst 


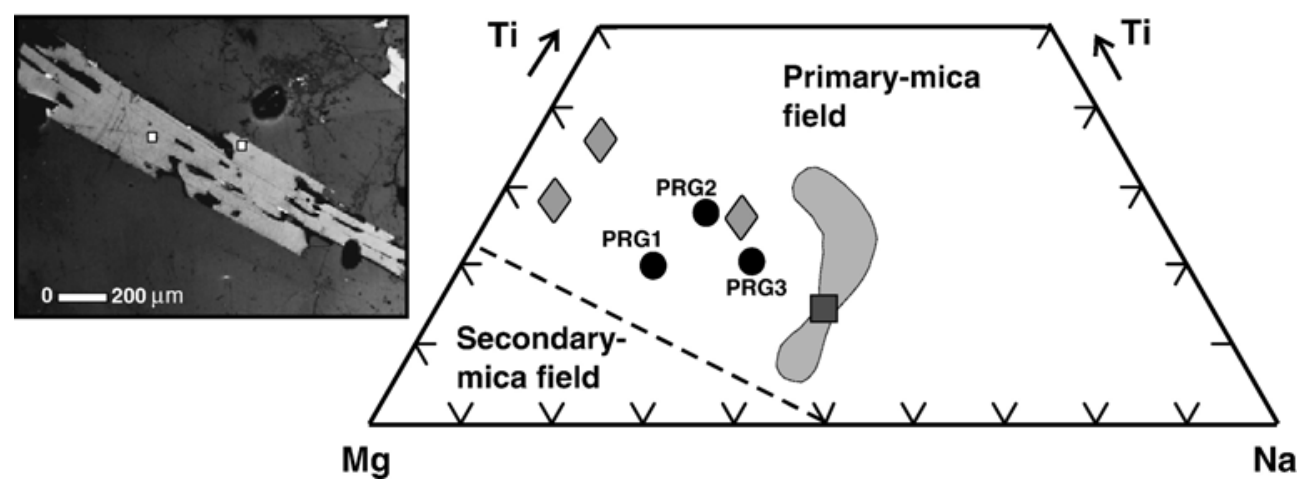

Fig. 6. Projected composition of white micas in the triangular diagram Mg-Ti-Na (data in Table 2e). The limit between fields for secondary and primary micas is from Miller et al. (1981). Grey field is representative of the white micas compositions in cordierite-bearing granitoids of Sierra de Chepes (Dahlquist et al., 2005b; data is showed in Table 2e). Filled rhombus are representative magmatic muscovite in garnet-bearing granitoids according to Kebede et al. (2001). Filled square is a typical value of $\mathrm{Mg}-\mathrm{Ti}-\mathrm{Na}$ from white micas (53 samples) crystallized in andalusite-bearing granites (Clarke et al., 2005; data is showed in Table 2e). Main inset shows representative primary white micas in PRG1 facies and the localization of two analyses (white squares). PRG: Peñón Rosado granite, facies 1, 2, and 3.

et al., 1998), and (d) a classical metaluminous suite defined in the original A-B diagram of Debon and Le Fort (1983) from a large database (Fig. 7a and b). The Peñón Rosado granite plots outside the main metaluminous trend and it is very difficult to envisage it as a differentiation product of metaluminous parent magma. The Peñón Rosado granite trend shown in Fig. $7 \mathrm{~b}$ falls in the peraluminous domain of the diagram of Debon and Le Fort (1983). The transition from $m-p-g$ (moderately peraluminous granitoids) to $f-p-g$ (felsic peraluminous granitoids) strongly suggests a magmatic suite in which the extension of PRG3 into the $f-p-g$ field represents a highly fractionated or residual peraluminous magma (see Villaseca et al., 1998). The Peñón Rosado granite trend is similar to those of the aluminous suites reported by Debon and Le Fort (1983).

The three main facies of the Peñon Rosado granite show a progressive increase in $\mathrm{SiO}_{2}$ in the Harker variation diagrams (Fig. 8 and Table 3). PRG1 has higher $\mathrm{CaO}, \mathrm{Na}_{2} \mathrm{O}, \mathrm{Al}_{2} \mathrm{O}_{3}$ and $\mathrm{MnO}$ concentrations, whereas PRG2 has higher $\mathrm{FeO}, \mathrm{MgO}, \mathrm{TiO}_{2}, \mathrm{P}_{2} \mathrm{O}_{5}$ and $\mathrm{K}_{2} \mathrm{O}$, and PRG3 has the highest $\mathrm{K}_{2} \mathrm{O}$ concentration. All major elements show a distinctive inflexion for the PRG2 facies $\left(\mathrm{SiO}_{2}=70.88 \%\right)$. The geochemical characteristics of the three facies are coherent with the magmatic mineral assemblage observed in each (e.g., PRG1 is plagioclaserich, PRG2 is biotite-rich, and PRG3 is K-feldspar-rich).

\subsubsection{Trace elements and REE}

Harker plots for some trace elements (e.g., Th, Hf, $\mathrm{Nb}, \mathrm{Ta}, \mathrm{Ga}$ ) also show an inflexion at $\mathrm{SiO}_{2}=70.88 \%$, interpreted as signifying a change in the crystallization sequence. In addition, the similarity between the trace element inter-relationships ( $\mathrm{Ba}, \mathrm{Sr}$ and $\mathrm{Rb}$ ) shown in
Fig. 8 and those modelled by different authors (e.g., McCarthy and Robb, 1978; Rapela and Shaw, 1979) indicate that the main mechanism of differentiation was fractional crystallization in a closed system, without significant contamination of the magma during its evolution. PRG1 and PRG2 exhibit similar Zr concentrations, whereas PRG3 is depleted in $\mathrm{Zr}$.

A distinctive chondrite-normalized REE pattern is exhibited by each PRG facies (Fig. 9 and Table 3). PRG1 has relatively low LREE and high HREE values ([La/ $\left.\mathrm{Yb}]_{\mathrm{N}}=1.78\right)$, with marked positive Eu-anomalies $(\mathrm{Eu} /$ $\mathrm{Eu}^{*}=1.95$ ), strongly suggesting that it is probably accumulate. Conversely, PRG2 is characterized by relatively high LREE and low HREE values $\left([\mathrm{La} / \mathrm{Yb}]_{\mathrm{N}}=8.31\right)$, with negative Eu-anomalies $\left(\mathrm{Eu} / \mathrm{Eu}^{*}=0.72\right)$. PRG3 is depleted in REE, with a flat pattern $\left([\mathrm{La} / \mathrm{Yb}]_{\mathrm{N}}=3.64\right)$ and slightly negative Eu-anomalies $\left(\mathrm{Eu} / \mathrm{Eu}^{*}=0.82\right)$.

\section{Geochronology}

Zircons were separated from sample VCA-7079 (PRG1 facies) at NERC Isotope Geosciences Laboratory, U.K., and analysed for $\mathrm{U}-\mathrm{Pb}$ isotopic composition using SHRIMP RG at The Australian National University, Canberra (as in Williams, 1998). The zircons are quite variable in morphology, with length: breadth ratios ranging from $\sim 1$ to $\sim 3$, the latter up to $250 \mu \mathrm{m}$ long, and mostly subhedral. Cathodo-luminescence images (Fig. 10) show that the zircons are of crustal origin, with cores consisting of complex fragments of older grains (showing both sector-zoned and oscillatory zoned forms), overgrown by two stages of low-luminescence zircon thought to be related to crystallization of granite magma formed by anatexis. In order to define the 
Table 2e

Representative compositions of white micas in Peñón Rosado granite from electron microprobe analyses and structural formulae

\begin{tabular}{|c|c|c|c|c|c|}
\hline \multirow{2}{*}{$\frac{\text { Igneous unit }}{\text { Igneous facies }}$} & \multicolumn{3}{|l|}{ PRG } & \multirow{2}{*}{$\frac{\mathrm{TG}^{\mathrm{a}}}{\mathrm{TUA}-246,49}$} & \multirow{2}{*}{$\frac{\mathrm{AG}^{\mathrm{b}}}{\text { Plutonic rocks }}$} \\
\hline & PRG1 & PRG2 & PRG3 & & \\
\hline Sample/s & VCA-7079 & ASP-114 & ASP-111 & & \\
\hline Analysis number & Av. $(n=4)$ & Av. $(n=2)$ & Av. $(n=5)$ & Av. $(n=5)$ & Av. $(n=53)$ \\
\hline Mineral & $\mathrm{WM}^{\mathrm{c}}$ & WM & WM & WM & WM \\
\hline \multicolumn{6}{|l|}{$w t . \%$} \\
\hline $\mathrm{SiO}_{2}$ & $45.39 \pm 0.24$ & $44.28 \pm 0.07$ & $44.85 \pm 0.88$ & $45.39 \pm 0.39$ & $45.43 \pm 0.55$ \\
\hline $\mathrm{TiO}_{2}$ & $0.68 \pm 0.02$ & $0.65 \pm 0.02$ & $0.71 \pm 0.06$ & $0.84 \pm 0.33$ & $0.55 \pm 0.53$ \\
\hline $\mathrm{Al}_{2} \mathrm{O}_{3}$ & $32.01 \pm 0.42$ & $33.96 \pm 0.00$ & $33.22 \pm 0.26$ & $33.23 \pm 0.41$ & $35.21 \pm 1.44$ \\
\hline $\mathrm{FeO}$ & $4.23 \pm 0.08$ & $3.22 \pm 0.05$ & $3.47 \pm 0.13$ & $3.49 \pm 0.16$ & $1.83 \pm 0.68$ \\
\hline $\mathrm{MnO}$ & $0.03 \pm 0.02$ & $0.01 \pm 0.01$ & $0.03 \pm 0.02$ & $0.03 \pm 0.03$ & $0.03 \pm 0.03$ \\
\hline $\mathrm{MgO}$ & $1.03 \pm 0.09$ & $0.62 \pm 0.01$ & $0.83 \pm 0.05$ & $0.75 \pm 0.05$ & $0.85 \pm 0.41$ \\
\hline $\mathrm{CaO}$ & $0.04 \pm 0.02$ & bdl & $0.01 \pm 0.01$ & bdl & $0.01 \pm 0.02$ \\
\hline $\mathrm{Na}_{2} \mathrm{O}$ & $0.34 \pm 0.07$ & $0.24 \pm 0.01$ & $0.42 \pm 0.04$ & $0.60 \pm 0.05$ & $0.65 \pm 0.18$ \\
\hline $\mathrm{K}_{2} \mathrm{O}$ & $10.50 \pm 0.23$ & $11.04 \pm 0.14$ & $11.30 \pm 0.20$ & $10.28 \pm 0.28$ & $10.44 \pm 0.26$ \\
\hline $\mathrm{F}$ & $0.08 \pm 0.07$ & bdl & $0.10 \pm 0.02$ & $0.03 \pm 0.03$ & $0.58 \pm 0.32$ \\
\hline $\mathrm{Cl}$ & $0.02 \pm 0.01$ & $0.02 \pm 0.01$ & $0.01 \pm 0.01$ & bdl & nd \\
\hline Total & $94.35 \pm 0.52$ & $94.01 \pm 0.05$ & $95.00 \pm 0.99$ & $94.68 \pm 0.48$ & $95.58 \pm 0.41$ \\
\hline O_F_Cl & $0.04 \pm 0.03$ & $0.01 \pm 0.01$ & $0.04 \pm 0.01$ & $0.01 \pm 0.01$ & 0.24 \\
\hline CTotal & $94.31 \pm 0.52$ & $94.01 \pm 0.05$ & $94.95 \pm 0.99$ & $94.67 \pm 0.49$ & 95.24 \\
\hline \multicolumn{6}{|c|}{ Structural formulae calculated on basis $22 \mathrm{O}$} \\
\hline $\mathrm{Si}$ & 6.22 & 6.07 & 6.11 & $6.16 \pm 0.05$ & 6.09 \\
\hline $\mathrm{Al}^{\mathrm{IV}}$ & 1.78 & 1.93 & 1.89 & $1.84 \pm 0.05$ & 1.91 \\
\hline Sum- $\mathrm{T}$ & 8.00 & 8.00 & 8.00 & $8.00 \pm 0.00$ & 8.00 \\
\hline $\mathrm{Al}^{\mathrm{VI}}$ & 3.38 & 3.55 & 3.45 & $3.47 \pm 0.06$ & 3.65 \\
\hline $\mathrm{Ti}$ & 0.07 & 0.07 & 0.07 & $0.09 \pm 0.03$ & 0.06 \\
\hline $\mathrm{Fe}^{2+}$ & 0.49 & 0.37 & 0.40 & $0.40 \pm 0.18$ & 0.21 \\
\hline $\mathrm{Mn}$ & 0.00 & 0.00 & 0.00 & 0.00 & 0.00 \\
\hline $\mathrm{Mg}$ & 0.21 & 0.13 & 0.17 & $0.15 \pm 0.01$ & 0.17 \\
\hline Sum-B & 4.15 & 4.12 & 4.09 & $4.11 \pm 0.04$ & 4.09 \\
\hline $\mathrm{Ca}$ & 0.01 & 0.00 & 0.00 & 0.00 & 0.00 \\
\hline $\mathrm{Na}$ & 0.09 & 0.06 & 0.11 & $0.16 \pm 0.01$ & 0.17 \\
\hline K & 1.84 & 1.93 & 1.96 & $1.78 \pm 0.13$ & 1.79 \\
\hline Sum-A & 1.94 & 1.99 & 2.07 & $1.94 \pm 0.12$ & 1.96 \\
\hline $\mathrm{CF}$ & 0.07 & 0.00 & 0.08 & $0.03 \pm 0.03$ & 0.49 \\
\hline $\mathrm{CCl}$ & 0.01 & 0.01 & 0.01 & 0.00 & 0.00 \\
\hline $\mathrm{Fe}^{2+} /\left(\mathrm{Fe}^{2+}+\mathrm{Mg}\right)$ & 0.70 & 0.75 & 0.70 & $0.72 \pm 0.02$ & 0.55 \\
\hline
\end{tabular}

References as in Table 2a for the plagioclases in PRG1. $\mathrm{C}=$ calculated. $\mathrm{LFD}=$ late felsic dyke. $\mathrm{WM}=$ white mica. nd= not determined.

${ }^{a}$ White micas in Tuaní Granite unit (cordierite-bearing granitoids), database from Dahlquist et al. (2005b).

${ }^{\mathrm{b}}$ White micas in andalusite-bearing granitoids, database from Clarke et al. (2005).

${ }^{c}$ Representative composition of white mica (used in geothermobarometry and fractional crystallization model using major oxides, which result from the average of 4 samples (explanation in Section 7).

crystallization age of the granitoid, analysis spots were targeted in the non-luminescent rims. Eight such analyses were carried out (Table 4) and are plotted in a Tera-Wasserburg diagram (Fig. 10). Eliminating two results in which inheritance had clearly not been fully avoided, the remaining six data points give a welldefined crystallization age of $469 \pm 4 \mathrm{Ma}(95 \%$ c.l. error, MSWD =0.7). This dates emplacement of the Peñón Rosado granite within the Mid-Ordovician according to Gradstein et al. (2004), and corresponds to ArenigLlanvirn in traditional stratigraphical terms. This age is typical of Famatinian granitoids (Pankhurst et al., 1998, 2000).

\section{Isotopic geochemistry}

The Peñón Rosado granite has high initial range ${ }^{87} \mathrm{Sr} /{ }^{86} \mathrm{Sr}$ ratios from 0.70814 to 0.71093 and negative $\varepsilon(\mathrm{Nd}) t$ values from -5.0 to -5.9 (Table 5). High Nd $T_{\mathrm{DM}}$ ages of 1.59 to $1.65 \mathrm{Ga}$ (Table 5) were obtained using the multistage model of DePaolo et al. (1991). These isotopic data indicate that the parental magma was probably 
Table 3

Representative major and trace element data of the Peñón Rosado granite and metaluminous granitoids in Cerro Asperecito

\begin{tabular}{|c|c|c|c|c|c|c|c|}
\hline \multirow{3}{*}{$\begin{array}{l}\text { Igneous } \\
\text { facies } \\
\text { Sample } \\
\end{array}$} & \multicolumn{7}{|c|}{ Peñón Rosado granite } \\
\hline & PRG1 & \multicolumn{3}{|l|}{ PRG2 } & \multicolumn{3}{|l|}{ PRG3 } \\
\hline & VCA-7079 & \multirow{2}{*}{$\frac{\text { ASP-108 }}{\text { Garnet-Tn }}$} & \multirow{2}{*}{$\frac{\text { ASP-114 }}{\text { Garnet-Tn }}$} & \multirow{2}{*}{$\frac{\text { ASP-216 }}{\text { Garnet-Tn }}$} & \multirow{2}{*}{$\frac{\text { ASP-215 }}{\text { Garnet-Mg }}$} & \multirow{2}{*}{$\frac{\text { ASP-217 }}{\text { Garnet-Mg }}$} & \multirow{2}{*}{$\frac{\text { ASP-214 }}{\text { Garnet-Mg }}$} \\
\hline Lithology & Garnet-Tdh & & & & & & \\
\hline \multicolumn{8}{|l|}{$w t . \%$} \\
\hline $\mathrm{SiO}_{2}$ & 65.70 & 70.40 & 70.80 & 71.44 & 73.98 & 74.34 & 74.38 \\
\hline $\mathrm{TiO}_{2}$ & 0.20 & 0.33 & 0.27 & 0.28 & 0.12 & 0.10 & 0.15 \\
\hline $\mathrm{Al}_{2} \mathrm{O}_{3}$ & 18.95 & 14.57 & 14.63 & 15.32 & 14.75 & 14.75 & 14.00 \\
\hline $\mathrm{Fe}_{2} \mathrm{O}_{3}^{\mathrm{t}}$ & 2.71 & 3.41 & 2.99 & 3.21 & 1.44 & 1.42 & 1.90 \\
\hline $\mathrm{MnO}$ & 0.44 & 0.10 & 0.10 & 0.14 & 0.09 & 0.08 & 0.08 \\
\hline $\mathrm{MgO}$ & 0.84 & 1.10 & 0.91 & 0.93 & 0.40 & 0.33 & 0.48 \\
\hline $\mathrm{CaO}$ & 4.11 & 3.66 & 3.18 & 3.66 & 2.03 & 1.59 & 2.42 \\
\hline $\mathrm{Na}_{2} \mathrm{O}$ & 5.32 & 3.12 & 3.46 & 3.40 & 3.50 & 3.34 & 3.45 \\
\hline $\mathrm{K}_{2} \mathrm{O}$ & 1.10 & 1.77 & 2.12 & 1.83 & 3.55 & 4.03 & 2.84 \\
\hline $\mathrm{P}_{2} \mathrm{O}_{5}$ & 0.05 & 0.15 & 0.11 & 0.14 & 0.08 & 0.09 & 0.08 \\
\hline LOI & 0.63 & 0.55 & 0.40 & 0.39 & 0.39 & 0.61 & 0.86 \\
\hline Total & 100.05 & 99.16 & 98.97 & 100.64 & 100.32 & 100.69 & 100.64 \\
\hline \multicolumn{8}{|l|}{ ppm } \\
\hline Cs & 3.30 & 2.82 & 1.88 & 2.20 & 2.10 & 1.60 & 2.20 \\
\hline $\mathrm{Rb}$ & 49.00 & 73.48 & 81.89 & 66.00 & 86.00 & 97.00 & 78.00 \\
\hline $\mathrm{Sr}$ & 248.00 & 214.00 & 200.90 & 202.00 & 152.00 & 105.00 & 148.00 \\
\hline $\mathrm{Ba}$ & 107.00 & 360.87 & 392.35 & 316.00 & 601.00 & 391.00 & 447.00 \\
\hline $\mathrm{La}$ & 17.40 & 36.65 & 38.19 & 20.90 & 13.00 & 12.30 & 17.60 \\
\hline $\mathrm{Ce}$ & 36.80 & 74.56 & 77.83 & 43.40 & 27.50 & 26.90 & 36.80 \\
\hline $\mathrm{Nd}$ & 11.00 & 29.44 & 30.17 & 4.76 & 3.00 & 2.95 & 4.09 \\
\hline $\operatorname{Pr}$ & 3.19 & 7.77 & 8.08 & 17.80 & 11.00 & 11.60 & 15.30 \\
\hline $\mathrm{Sm}$ & 1.98 & 5.63 & 6.05 & 3.59 & 2.45 & 2.73 & 3.43 \\
\hline $\mathrm{Eu}$ & 1.10 & 1.17 & 1.21 & 0.95 & 0.79 & 0.63 & 0.80 \\
\hline $\mathrm{Gd}$ & 1.52 & 4.48 & 5.23 & 3.36 & 2.42 & 2.74 & 3.47 \\
\hline $\mathrm{Tb}$ & 0.40 & 0.67 & 0.90 & 0.58 & 0.43 & 0.54 & 0.65 \\
\hline Dy & 3.83 & 3.34 & 5.04 & 3.71 & 2.68 & 3.29 & 3.88 \\
\hline Но & 1.10 & 0.63 & 1.06 & 0.84 & 0.56 & 0.65 & 0.78 \\
\hline $\mathrm{Er}$ & 4.38 & 1.86 & 3.21 & 2.77 & 1.73 & 1.95 & 2.41 \\
\hline $\mathrm{Tm}$ & 0.90 & 0.27 & 0.48 & 0.46 & 0.29 & 0.31 & 0.38 \\
\hline $\mathrm{Yb}$ & 6.54 & 1.67 & 2.88 & 3.17 & 1.93 & 2.00 & 2.53 \\
\hline $\mathrm{Lu}$ & 1.16 & 0.28 & 0.46 & 0.50 & 0.28 & 0.29 & 0.38 \\
\hline U & 0.91 & 0.98 & 1.35 & 0.85 & 0.79 & 1.35 & 1.11 \\
\hline Th & 4.60 & 11.12 & 12.51 & 7.17 & 4.72 & 4.82 & 6.40 \\
\hline Y & 32.10 & 14.85 & 25.38 & 22.70 & 16.30 & 19.10 & 24.20 \\
\hline $\mathrm{Nb}$ & 7.70 & 14.44 & 11.49 & 11.70 & 5.20 & 4.90 & 7.00 \\
\hline $\mathrm{Zr}$ & 117.00 & 127.68 & 119.49 & 109.00 & 56.00 & 46.00 & 82.00 \\
\hline Hf & 3.30 & 4.01 & 3.88 & 3.10 & 1.90 & 1.70 & 2.30 \\
\hline $\mathrm{Ta}$ & 0.49 & 0.62 & 0.73 & 0.84 & 0.33 & 0.28 & 1.37 \\
\hline $\mathrm{Ga}$ & 20.00 & 14.83 & 14.87 & 12.00 & 10.00 & 10.00 & 13.00 \\
\hline $\mathrm{Ge}$ & 1.40 & 1.65 & 2.05 & 1.60 & 1.80 & 1.80 & 2.40 \\
\hline$A S I$ & 1.10 & 1.09 & 1.08 & 1.40 & 1.13 & 1.12 & 0.93 \\
\hline \multirow[t]{2}{*}{ Igneous facies } & \multicolumn{3}{|c|}{ Peñón Rosado granite } & & \multicolumn{3}{|c|}{ Metaluminous suites } \\
\hline & \multicolumn{3}{|c|}{ PRG2 } & \multicolumn{2}{|l|}{ LFD } & & \\
\hline Sample & & & ASP-218 & $\mathrm{ASP}$ & & Average $^{\mathrm{a}}$ & ASP-119 \\
\hline Lithology & & $-\mathrm{Mg}$ & Garnet-Mg & Garn & & $\mathrm{Tn} / \mathrm{Gd}$ & $\mathrm{Mg}$ \\
\hline$w t . \%$ & & & & & & & \\
\hline $\mathrm{SiO}_{2}$ & & & 75.66 & 74.8 & & $61.99 \pm 0.98$ & 73.81 \\
\hline $\mathrm{TiO}_{2}$ & & & 0.04 & 0.0 & & $0.72 \pm 0.11$ & 0.14 \\
\hline
\end{tabular}


Table 3 (continued)

\begin{tabular}{|c|c|c|c|c|c|}
\hline \multirow[t]{2}{*}{ Igneous facies } & \multicolumn{3}{|c|}{ Peñón Rosado granite } & \multicolumn{2}{|c|}{ Metaluminous suites } \\
\hline & \multicolumn{2}{|l|}{ PRG3 } & \multicolumn{3}{|l|}{ LFD } \\
\hline Sample & ASP-111 & ASP-218 & ASP-112 & Average $^{\mathrm{a}}$ & ASP-119 \\
\hline Lithology & Garnet-Mg & Garnet-Mg & Garnet-FR & $\mathrm{Tn} / \mathrm{Gd}$ & $\mathrm{Mg}$ \\
\hline \multicolumn{6}{|l|}{$w t . \%$} \\
\hline $\mathrm{Al}_{2} \mathrm{O}_{3}$ & 14.33 & 14.62 & 14.09 & $15.89 \pm 0.24$ & 13.96 \\
\hline $\mathrm{Fe}_{2} \mathrm{O}_{3}^{\mathrm{t}}$ & 0.81 & 0.78 & 0.72 & $7.07 \pm 0.48$ & 1.60 \\
\hline $\mathrm{MnO}$ & 0.09 & 0.05 & 0.22 & $0.13 \pm 0.01$ & 0.04 \\
\hline $\mathrm{MgO}$ & 0.14 & 0.12 & 0.07 & $2.67 \pm 0.13$ & 0.32 \\
\hline $\mathrm{CaO}$ & 1.09 & 1.12 & 2.51 & $5.05 \pm 0.41$ & 0.92 \\
\hline $\mathrm{Na}_{2} \mathrm{O}$ & 3.38 & 3.39 & 4.53 & $2.50 \pm 0.28$ & 2.91 \\
\hline $\mathrm{K}_{2} \mathrm{O}$ & 4.81 & 4.55 & 1.66 & $2.19 \pm 0.31$ & 5.36 \\
\hline $\mathrm{P}_{2} \mathrm{O}_{5}$ & 0.09 & 0.09 & 0.07 & $0.21 \pm 0.04$ & 0.21 \\
\hline LOI & 0.59 & 0.48 & 0.29 & $0.98 \pm 0.14$ & 0.65 \\
\hline Total & 99.93 & 100.90 & 98.98 & $99.40 \pm 0.54$ & 99.92 \\
\hline \multicolumn{6}{|l|}{ ppm } \\
\hline Cs & 1.79 & 5.00 & 0.80 & $4.65 \pm 1.13$ & 8.68 \\
\hline $\mathrm{Rb}$ & 149.17 & 123.00 & 40.60 & $98.92 \pm 17.7$ & 243.21 \\
\hline $\mathrm{Sr}$ & 52.64 & 64.00 & 126.13 & $182.00 \pm 13.2$ & 54.49 \\
\hline $\mathrm{Ba}$ & 170.16 & 217.00 & 207.29 & $360.29 \pm 73.4$ & 226.29 \\
\hline $\mathrm{La}$ & 3.83 & 5.24 & 8.24 & $27.78 \pm 2.69$ & 26.45 \\
\hline $\mathrm{Ce}$ & 8.05 & 11.40 & 14.06 & $59.47 \pm 4.45$ & 56.25 \\
\hline $\mathrm{Nd}$ & 3.12 & 1.27 & 4.52 & $22.29 \pm 1.30$ & 22.35 \\
\hline $\operatorname{Pr}$ & 0.83 & 5.73 & 1.32 & $5.80 \pm 0.30$ & 5.99 \\
\hline $\mathrm{Sm}$ & 0.99 & 1.48 & 1.00 & $4.61 \pm 0.58$ & 5.52 \\
\hline $\mathrm{Eu}$ & 0.36 & 0.40 & 0.62 & $1.10 \pm 0.16$ & 0.67 \\
\hline $\mathrm{Gd}$ & 1.18 & 1.64 & 0.96 & $3.84 \pm 0.94$ & 4.85 \\
\hline $\mathrm{Tb}$ & 0.27 & 0.34 & 0.24 & $0.66 \pm 0.19$ & 0.9 \\
\hline Dy & 1.94 & 2.27 & 1.85 & $3.98 \pm 0.85$ & 5.00 \\
\hline Ho & 0.39 & 0.44 & 0.48 & $0.79 \pm 0.20$ & 0.90 \\
\hline $\mathrm{Er}$ & 1.36 & 1.33 & 1.92 & $2.32 \pm 0.62$ & 2.54 \\
\hline $\mathrm{Tm}$ & 0.24 & 0.23 & 0.39 & $0.33 \pm 0.09$ & 0.36 \\
\hline $\mathrm{Yb}$ & 1.62 & 1.48 & 2.84 & $2.06 \pm 0.34$ & 2.07 \\
\hline $\mathrm{Lu}$ & 0.26 & 0.21 & 0.49 & $0.31 \pm 0.08$ & 0.30 \\
\hline $\mathrm{U}$ & 0.89 & 1.05 & 0.55 & $0.76 \pm 0.24$ & 2.23 \\
\hline Th & 0.94 & 1.95 & 1.49 & $6.68 \pm 1.45$ & 12.32 \\
\hline $\mathrm{Y}$ & 10.37 & 13.00 & 11.57 & $20.58 \pm 4.05$ & 24.26 \\
\hline $\mathrm{Nb}$ & 7.63 & 3.60 & 3.03 & $9.89 \pm 0.83$ & 16.87 \\
\hline $\mathrm{Zr}$ & 28.35 & 19.00 & 31.58 & $180.30 \pm 64.3$ & 87.07 \\
\hline $\mathrm{Hf}$ & 1.27 & 1.00 & 1.58 & $4.58 \pm 1.21$ & 3.17 \\
\hline $\mathrm{Ta}$ & 0.27 & 0.30 & 0.08 & $0.53 \pm 0.04$ & 1.56 \\
\hline $\mathrm{Ga}$ & 12.29 & 10.00 & 11.55 & $17.60 \pm 1.33$ & 16.70 \\
\hline $\mathrm{Ge}$ & 3.41 & 2.40 & 3.25 & $1.67 \pm 0.31$ & 2.12 \\
\hline ASI & 1.14 & 1.05 & 1.03 & 1.05 & 1.19 \\
\hline
\end{tabular}

All major element oxides were analysed by ICP and trace element were analysed by ICP-MS in ACTLABS Canada. Total iron as Fe ${ }_{2} \mathrm{O}_{3}$; major element oxides in wt.\%, trace element in ppm. Abbreviations: $\mathrm{Tdh}=$ trondhjemites; $\mathrm{Tn}=$ tonalites; $\mathrm{Gd}=$ granodiorites, $\mathrm{Mg}=$ monzogranites; FR: felsic rocks; PRG: Peñón Rosado granite; $\mathrm{LFD}=$ late felsic dykes; $\mathrm{LOI}=$ loss on ignition; bdl=below detection limit; $\mathrm{nd}=$ not determined. $\mathrm{ASI}=$ aluminium saturation index.

${ }^{a}$ Average from 5 samples. Samples from metaluminous suite in Cerro Asperecito are projected in Fig. $7 \mathrm{a}$ and $\mathrm{b}$.

derived by partial melting of older lithosphere (middle crustal?), with negligible asthenospheric contribution.

\section{Petrogenetic model}

In order to define the main differentiation process during the crystallization, we have assessed two mathematical models as discussed below.

\subsection{Fractional crystallization model based on major oxides}

On the basis of the preceding observations (see Section 3.4.) it was assumed that the main mechanism of differentiation was fractional crystallization in a closed system, without significant contamination of the magma during its evolution. The fractionating mineral 
a
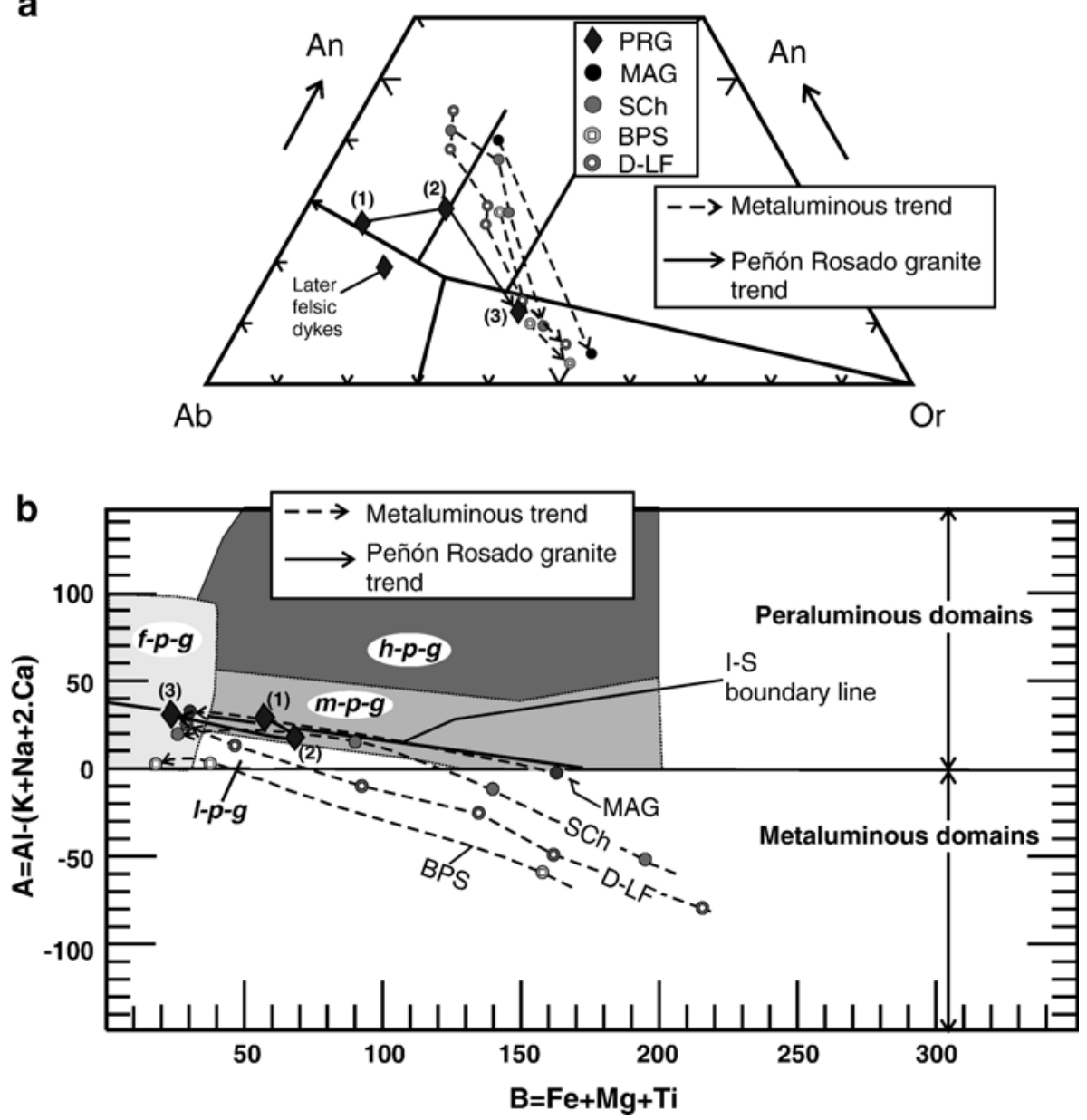

Fig. 7. (a) Granitoids plotted in terms of Ab-An-Or (Barker, 1979), showing different metaluminous trends and Peñón Rosado granite trend. (a) $\mathrm{SCh}=$ Sierra de Chepes metaluminous trend from Dahlquist et al. (2005a), including MME, Tn-Gd,GP, and Mz. MAG=metaluminous Asperecito granitoids, including Tn and Mz (data in Table 3); (b) BPS=Boggy Plain Metaluminous Supersuite, Lachlan Fold Belt, from Wyborn et al. (1987), including Gd, Ad, and Mz; (c) D-LF=Calc-alkaline metaluminous suites from the database of Debon and Le Fort (1983), including QD, MD, Tn, Gd, Ad, and Mz. The number next to each rhombus corresponds to the specific PRG facies in the Peñón Rosado granite. PRG1 (VCA7079), $\mathrm{SiO}_{2}=65.70 \%$; PRG2 (average 3 samples), $\mathrm{SiO}_{2}=70.88 \%$; and $\mathrm{PRG} 3$ (average 5 samples), $\mathrm{SiO}_{2}=74.59 \%$. QD $=\mathrm{quartz}$ diorite, $\mathrm{MD}=$ monzodiorite, $\mathrm{MME}=$ mafic microgranular enclaves, $\mathrm{Tn}=$ tonalites, $\mathrm{Gd}=$ granodiorites, $\mathrm{GP}=$ porphyritic granodiorites, Ad=adamellites, $\mathrm{Mz}=$ monzogranites. (b) A-B diagram after Debon and Le Fort (1983) and Villaseca et al. (1998), showing overall major element variation for the different metaluminous suites of $(a)$. References in (a) I-S boundary line taken from Villaseca et al. (1998). Two different compositional domains are shown in the diagram, according to Debon and Le Fort (1983): with metaluminous area $\mathrm{A}<0$ and peraluminous area A $>0$. Fields are: f-p-g (felsic peraluminous granitoids); h-p-g (highly peraluminous granitoids); m-p-g (moderately peraluminous granitoids); and 1-p-g (low peraluminous granitoids).

assemblage in PRG1 is dominated by plagioclase (Table 1 and Fig. 8), with a significant change to produce the inflexion at $\sim 71 \% \mathrm{SiO}_{2}$, coinciding with the switch to PRG2. Many authors have interpreted such abrupt inflections in element abundances as evidence for fractional crystallization as the principal process of magmatic differentiation (McCarthy and Robb, 1978; McCarthy and Groves, 1979; Rapela and Shaw, 1979; Chappell, 1997). Thus, during the crystallization of the PRG1 facies, large amounts of plagioclase were extracted yielding the increased concentration in this facies of, e.g., $\mathrm{CaO}, \mathrm{Na}_{2} \mathrm{O}$, $\mathrm{Al}_{2} \mathrm{O}_{3}$, and Sr. Subsequently, voluminous biotite crystallization (together with apatite and monazite as distinctive accessory minerals) is verified in the PRG2 facies (Table 1), yielding the increase in $\mathrm{FeO}^{\mathrm{t}}, \mathrm{MgO}$, $\mathrm{TiO}_{2}$, and $\mathrm{P}_{2} \mathrm{O}_{5}$ (Fig. 8). As outcome of the fractionation of these elements in the PRG1 and 
PRG2 facies, they are depleted in the $\mathrm{SiO}_{2}$-rich rocks of PRG3 and the felsic late dykes (Fig. 8). The enrichment of $\mathrm{K}_{2} \mathrm{O}$ and the trace element $(\mathrm{Rb}, \mathrm{Sr}, \mathrm{Ba})$ inter-relationships shown in Fig. 8 for PRG3 indicate that abundant alkali feldspar appears in this facies after total crystallization of PRG2 (McCarthy and Robb, 1978; Rapela and Shaw, 1979).

Samples were chosen for use in fractional crystallization model taking into account textural relationships and both whole-rock and mineral chemistry. Thus, the VCA-7079 composition was assumed to represent the early crystallization of the PRG1 facies and the average composition of ASP-108, 114, and 216 was taken as the resultant evolved melt (PRG2); the parental magma from which PRG1 rocks accumulated to produce the differentiated PRG2 facies magma is considered as being composed of $30 \%$ of the former and $70 \%$ of the latter. A 30:70 mixture was chosen as representative of the parental magma because this yields the best fit in the fractional crystallization model (in the next section, this parental magma composition is also tested in a fractional crystallization model using REE). Least-square regression methods for modelling the segregation of crystallizing minerals (Bryan et al., 1969; Walker and Carr, 1986) were performed using IGPET program (Carr, 1998). Details of the calculations and the results are shown in Table 6 and Fig. 8. The fractional crystallization calculation shows a very acceptable $\sum R^{2}$ value (=sum of the squares of the residuals) for plutonic rocks (Dahlquist, 2002; Gomes and Neiva, 2005), and the calculated modal value of the early crystallized is similar to that of the sample analysed by electron microprobe (VCA-7079, PRG1 facies, Table 6). Nevertheless, the natural variables involved during magma crystallization in plutonic systems means that the numerical results of modelling (e.g., relative percentages of fractionating minerals) should be taken as no more than approximations to reality.

\subsection{Fractional crystallization model based on trace elements}

The same samples were also used for a trace element fractional crystallization model and geothermobarometry determinations (see Section 7). A quantitative trace element model was developed to compare the observed composition of the PRG2 with those obtained by calculation using the approach of Hanson (1978). The concentration of any trace element in the differentiated melt $\left(C^{L}\right)$ relative to that in the parent melt $\left(C_{0}\right)$ during fractional crystallization is given by the Rayleigh fractionation law:

$C^{\mathrm{L}}=C_{0} \cdot F^{(D-1)}$

where $F$ is the fraction of melt remaining and $D$ is the bulk distribution coefficient of the fractionating assemblage, given by $D=\Sigma X_{i} \cdot K_{i}$, where $X_{i}$ is the proportion of each mineral, and $K^{i / l}$ is its mineral-melt partition coefficient. $F=0.55$ as well as the initial concentration of REE elements were chosen from the results obtained in the previous section and both are shown in Table 7. $K_{i}$ was assumed to be constant during the crystallization process; the values used and other details are founded in Table 7. There is a close correspondence between the observed and calculated values of $C^{\mathrm{L}}$ (differentiated melt) and $C^{\mathrm{S}}$ (cumulate), as is evident in Fig. 9.

Both fractional crystallization models using major oxides or trace element are consistent with PRG1 being a cumulate assemblage and PRG2 a differentiated melt, each derived from the hypothetical parental magma postulated here. Thus, the fractional crystallization was the main differentiation process in the Peñón Rosado granite.

\section{Geothermometers and geobarometer applicable to Peñón Rosado granite}

The texture and composition of garnet in the Peñón Rosado granite (Table 2c) are similar to those reported for typical magmatic garnet in granitic plutons (see Section 3.3 and discussion below). PRG1 biotites with high Mn contents (Table 2d) are typical of those crystallizing together with Mn-rich garnet (Leake, 1967; Miller and Stoddard, 1981). This suggests an equilibrium relationship between these two mineral phases, which were therefore used for geothermobarometric calculations. Anderson (1996) provided relevant recommendations for the use of the thermometer and barometer in igneous rocks and concluded that the Ganguly and Saxena (1984) geothermometer, using the $\mathrm{Fe}^{+2}$ and $\mathrm{Mg}$ partition between garnet and biotite, is the most robust version to account for the effects of high $\mathrm{Mn}$, when $\mathrm{CaO}<10 \%$. The $\mathrm{R} 2$ geobarometer model of Hoisch (1990) was used to calculate pressure, requiring the equilibrium crystallization of quartz, garnet, biotite, and plagioclase. The R3 model requires the crystallization of garnet, muscovite, quartz, and plagioclase minerals, whereas the R4 model requires crystallization of five mineral phases such as quartz, garnet, biotite, muscovite, and plagioclase. R3 and R4 yield unrealistic results, probably because the white mica compositional range of these models (Hoisch, 1990) does not correspond closely to that observed in the PRG1 facies. 

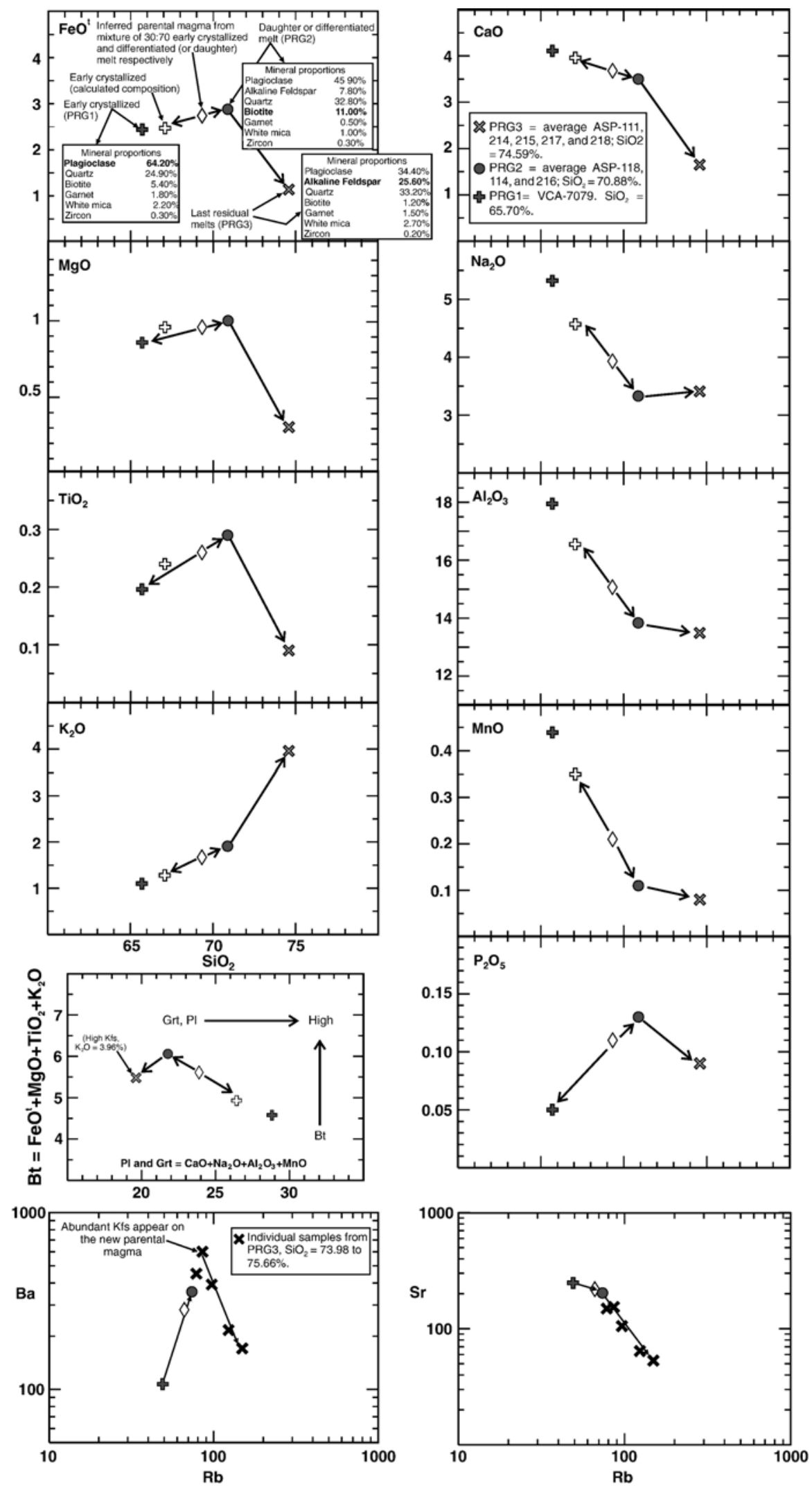


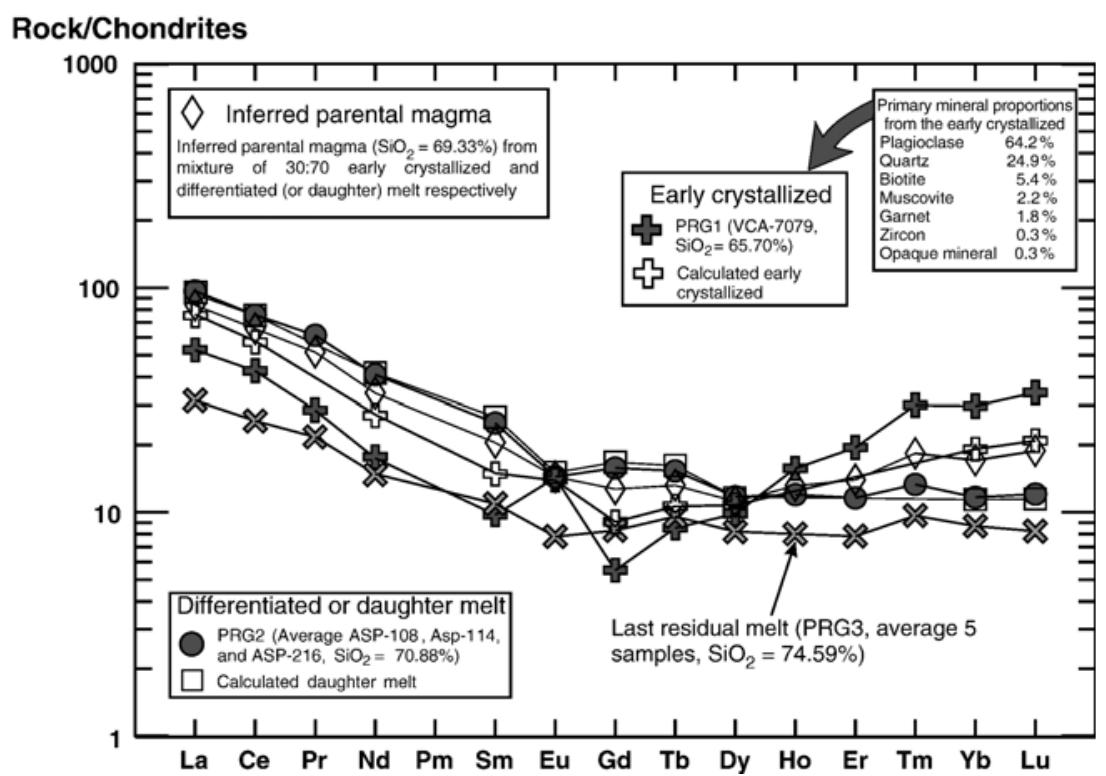

Fig. 9. Chondrite-normalized rare-earth element patterns for the Peñón Rosado granite. Results from the fractional crystallization model (empty rhombus, cross and circle) are shown in the figure and later explained in Section 6.2. The close agreement between observed and calculated patterns supports a fractional crystallization process. Chondrite concentrations according to Nakamura (1974). Tb, Ho, and Tm are according to Boynton (1984).

\subsection{Calculated temperature and pressure}

Compositional maps and zoning profiles of garnet in the PRG1 facies show three distinctive zones: a) central zone, b) intermediate compositional zone, and c) marginal rim zone, with a progressive increase in $\mathrm{MnO}$ (Fig. 5). The wide central zone was used to define the temperature of major garnet crystallization in this facies; an average of 7 representative analyses was used in combination with the average of 4 representative analyses from biotites (Table 8). The calibrations used here (Ganguly and Saxena, 1984; Hoisch, 1990) are functions of both pressure and the temperature. Therefore, they were solved by iteration, where the temperature obtained from the geothermometer was recalculated until it satisfied the pressure obtained from the geobarometer. The resultant temperature and pressure $\left(T=784{ }^{\circ} \mathrm{C}\right.$ and $P=5.9 \mathrm{~kb}$, Table 8$)$ are consistent with crystallization of garnet and biotite under magmatic conditions. The generally accepted intersection of the granite solidus curve with experimental curves for the reaction

$\mathrm{Ms}+\mathrm{Qtz}=\mathrm{Kfs}+\mathrm{Al}-$ silicates $+\mathrm{H}_{2} \mathrm{O}$

would suggest a depth of crystallization for muscovite in granitic magmas of at least 10-14 km (approximately 3-
$4 \mathrm{~kb}$ ), and is consistent with the geobarometric result. In addition, estimated $P$ and $T$ using TWQ (Berman, 1991) and the activity-composition model for garnet (Berman, 1990) and biotite (McMullin et al., 1991) reveal very similar conditions $\left(T=792{ }^{\circ} \mathrm{C}, P=6.0 \mathrm{~kb}\right.$; Table 8) to those obtained from the calibrations Ganguly and Saxena (1984) and Hoisch (1990). Finally, zircon saturation temperatures $\left(T_{\mathrm{Zr}}\right)$ calculated from bulk-rock compositions using the equation of Miller et al. (2003), yield a similar initial temperature of crystallization of $764{ }^{\circ} \mathrm{C}$ (Table 8). This $T_{\mathrm{Zr}}$ value is typical of granites rich in inherited zircon (average using 22 granitic samples= $766 \pm 24{ }^{\circ} \mathrm{C}$, Miller et al., 2003). The results shown in Table 8 are reasonable for granitic bodies emplaced in a migmatitic high-grade terrane with a biotite-sillimanite association, indicating that the garnet and the sheet minerals have a certain magmatic origin.

\section{Petrogenesis of the Peñón Rosado garnet pluton}

\subsection{Interpretation from petrography and mineral chemistry}

Previous descriptions of Mn-rich garnets from felsic granitic rocks have recorded both types of zoning seen in

Fig. 8. Harker variation diagrams showing the main trend defined by the different facies and $\mathrm{Ba}, \mathrm{Sr}, \mathrm{Rb}$ inter-relationships for the Peñón Rosado granite. Results from the fractional crystallization model (rhombus and empty cross) are shown in this figure and later explained in Section 6.1. Rhombus and empty cross represent calculated parental magma and early crystallized respectively. 
the Peñón Rosado granite (Section 3.3). Two main factors are operative in the formation of zoning: (a) the chemical potential $(\mu)$ value of the $\mathrm{MnO}$ component in the solid phase (garnet) relative to the chemical potential value of the $\mathrm{MnO}$ component in the melt phase, and (b) $\mathrm{Mn}$ diffusion within the crystal (Yardley, 1977; Manning, 1983; Spear, 1993). Taking the Gibbs free energy (see Ghiorso and Carmichael, 1987) for garnet saturation, we have for the crystallization reaction liquid $\rightarrow$ solid:

$\Delta G=\mu_{\mathrm{MnO}}^{\mathrm{Garnet}}-\mu_{\mathrm{MnO}}^{\mathrm{Melt}}$

so that if garnet is stable:

$\mu_{\mathrm{MnO}}^{\mathrm{Garnet}}<\mu_{\mathrm{MnO}}^{\mathrm{Melt}}$

(or $K_{\mathrm{D}}>1$, with $\mathrm{Mn}$ behaving as a trace element; e.g., Hollister, 1966; Atherton, 1968; Manning, 1983).

Because garnet crystallized throughout the crystallization sequence, expression (2) can be assumed as generally valid (our current understanding of the thermodynamics of silicate melts does not allow computation of the activity of Mn-bearing components in the melt, which vary as a function of $P-T$ and the mole fraction for every phase). Therefore, diffusion is the main variable to be taken into account. As explained by different authors (e.g., Leake, 1967; Clarke, 1981; Manning, 1983) garnet zoning is an intrinsic feature of the growth mechanism and is controlled by the rate at which the necessary constituents (mainly $\mathrm{Mn}$ and $\mathrm{Fe}$ in our case) can diffuse to, and within, the growing crystal. As shown by various authors (e.g. Yardley, 1977; Spear, 1993), diffusion becomes exponentially more rapid with increasing temperature and diffusion rates for $\mathrm{Mn}$ in garnet are negligible below about $640 \pm 30{ }^{\circ} \mathrm{C}$ (Yardley, 1977; Manning, 1983; Harrison, 1988), but self-diffusion of the Mn cation in spessartine-almandine garnet above $\sim 700{ }^{\circ} \mathrm{C}$ is sufficiently rapid to eliminate any compositional zoning during growth. Thus, the wide homogenous central zone (spessartine average $=28.96 \%$ for garnets in PRG1 and $23.11 \%$ in PRG2) implies crystallization at temperatures above $\sim 700{ }^{\circ} \mathrm{C}$, whereas the $\mathrm{Mn}$ enrichment in the marginal rims (spessartine average $=39.18 \%$ in PRG1 and $26.16 \%$ in PRG2) is due to retention and accumulation (negligible diffusion) of $\mathrm{Mn}$ during late crystallization at low temperatures (i.e., below $\sim 700{ }^{\circ} \mathrm{C}$, Fig. 5). The intermediate compositional zone of garnets in PRG1, with a spessartine range between 32.11 and $33.39 \%$, may represent growth between $\sim 700$ and $600{ }^{\circ} \mathrm{C}$ with rapidly

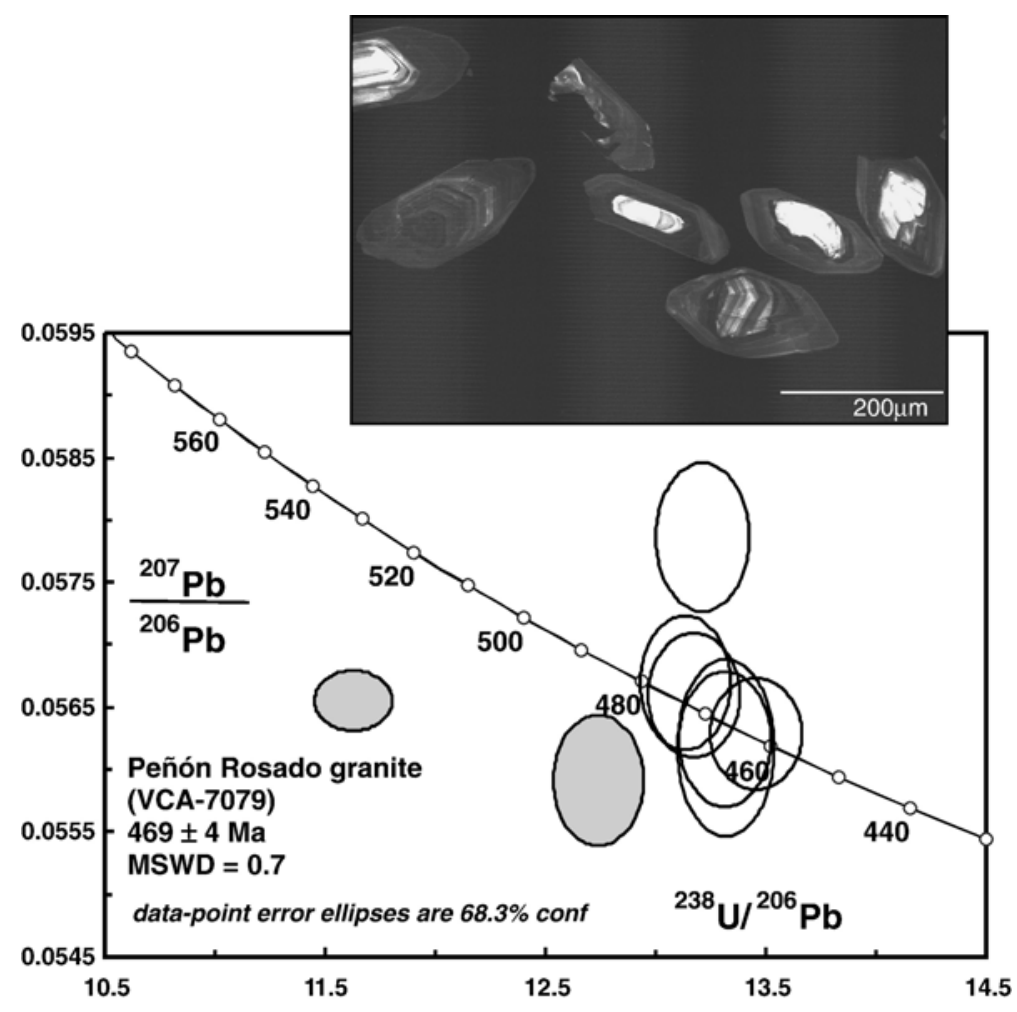

Fig. 10. Tera-Wasserburg diagrams for the Peñón Rosado granite (VCA-7079, PRG1 facies), error ellipses are 1; shaded points are excluded from the age calculation. 
Table 4

Summary of SHRIMP U-Pb zircon results for sample VCA-7079

\begin{tabular}{|c|c|c|c|c|c|c|c|c|c|c|c|c|c|c|}
\hline \multirow{2}{*}{$\begin{array}{l}\text { Grain. } \\
\text { spot }\end{array}$} & \multirow{2}{*}{$\begin{array}{l}\mathrm{U} \\
(\mathrm{ppm})\end{array}$} & \multirow{2}{*}{$\begin{array}{l}\text { Th } \\
\text { (ppm) }\end{array}$} & \multirow[t]{2}{*}{$\mathrm{Th} / \mathrm{U}$} & \multirow{2}{*}{$\begin{array}{c}{ }^{206} \mathrm{~Pb}^{*} \\
(\mathrm{ppm})\end{array}$} & \multirow[t]{2}{*}{${ }^{204} \mathrm{~Pb} /{ }^{206} \mathrm{~Pb}$} & \multirow{2}{*}{$\begin{array}{l}\mathrm{f}_{206} \\
\%\end{array}$} & \multicolumn{4}{|l|}{ Total } & \multicolumn{2}{|l|}{ Radiogenic } & \multicolumn{2}{|l|}{ Age (Ma) } \\
\hline & & & & & & & ${ }^{238} \mathrm{U} /{ }^{206} \mathrm{~Pb}$ & \pm & ${ }^{207} \mathrm{~Pb} /{ }^{206} \mathrm{~Pb}$ & \pm & ${ }^{206} \mathrm{~Pb} /{ }^{238} \mathrm{U}$ & \pm & ${ }^{206} \mathrm{~Pb} /{ }^{238} \mathrm{U}$ & \pm \\
\hline 1.1 & 863 & 42 & 0.05 & 56.3 & 0.000035 & 0.01 & 13.165 & 0.136 & 0.0566 & 0.0003 & 0.0759 & 0.0008 & 471.9 & 4.8 \\
\hline 2.1 & 747 & 39 & 0.05 & 48.9 & 0.000031 & 0.02 & 13.127 & 0.137 & 0.0567 & 0.0004 & 0.0762 & 0.0008 & 473.2 & 4.8 \\
\hline 3.1 & 650 & 20 & 0.03 & 42.3 & 0.000011 & 0.17 & 13.204 & 0.139 & 0.0579 & 0.0004 & 0.0756 & 0.0008 & 469.8 & 4.8 \\
\hline 4.1 & 771 & 68 & 0.09 & 52.1 & 0.000029 & $<0.01$ & 12.732 & 0.134 & 0.0559 & 0.0003 & 0.0786 & 0.0008 & 488.0 & 5.0 \\
\hline 5.1 & 744 & 34 & 0.05 & 48.0 & 0.000022 & $<0.01$ & 13.308 & 0.139 & 0.0562 & 0.0004 & 0.0752 & 0.0008 & 467.1 & 4.8 \\
\hline 6.1 & 457 & 19 & 0.04 & 29.5 & 0.000096 & $<0.01$ & 13.309 & 0.142 & 0.0562 & 0.0005 & 0.0752 & 0.0008 & 467.1 & 4.9 \\
\hline 7.1 & 1007 & 48 & 0.05 & 64.3 & 0.000030 & $<0.01$ & 13.449 & 0.139 & 0.0563 & 0.0003 & 0.0744 & 0.0008 & 462.3 & 4.7 \\
\hline 8.1 & 5295 & 33 & 0.01 & 391.4 & 0.000006 & $<0.01$ & 11.621 & 0.117 & 0.0566 & 0.0002 & 0.0862 & 0.0009 & 533.1 & 5.2 \\
\hline
\end{tabular}

Notes:1. Uncertainties given at the one s level.

2. Error in $\mathrm{FC} 1$ reference zircon calibration was $0.16 \%$ for the analytical session (not included in above errors but required when comparing data from different mounts).

3. $\mathrm{f}_{206} \%$ denotes the percentage of ${ }^{206} \mathrm{~Pb}$ that is common $\mathrm{Pb}$.

4. Correction for common $\mathrm{Pb}$ made using the measured ${ }^{238} \mathrm{U} /{ }^{206} \mathrm{~Pb}$ and ${ }^{207} \mathrm{~Pb} /{ }^{206} \mathrm{~Pb}$ ratios following Tera and Wasserburg (1972) as outlined in Williams (1998).

decreasing Mn diffusion. Similarly, the unzoned garnets in PRG3 involve crystallization at temperatures above $\sim 700^{\circ} \mathrm{C}$ and high $\mathrm{Mn}$ diffusion, and the absence of $\mathrm{Mn}$ enrichment in the rims suggests that crystallization ceased above $\sim 700{ }^{\circ} \mathrm{C}$. Thus the zoning profile of garnet in PRG1, as well as the geothermobarometric calculations (Table 8), indicate major garnet crystallization from a granitic magma at middle pressures $(6 \mathrm{~kb})$ and moderatelow magmatic temperatures $\left(764-792{ }^{\circ} \mathrm{C}\right.$ ) (Figs. 5 and 11). Remarkably, this is the main reason for which a "spessartine inverse bell-shaped profile" or unzoned is expected for magmatic garnets crystallizing above $\sim 700{ }^{\circ} \mathrm{C}$, and "spessartine bell-shaped profile" for $\mathrm{Mn}$ rich garnets growing under low-grade metamorphic conditions or crystallizing below $\sim 700{ }^{\circ} \mathrm{C}$ in very felsic magmas (i.e., $\mathrm{SiO}_{2}=73-76 \%$; Leake, 1967; Miller and Stoddard, 1981; Manning, 1983).

In the KFMASH system, a classic reaction proposed for the anatectic generation of peraluminous partial melt from metagreywackes (Vielzeuf and Holloway, 1988) (Fig. 11) is

$$
\mathrm{Pl}+\mathrm{Bt}+\mathrm{Sil}+\mathrm{Qtz}=\mathrm{Grt}_{\mathrm{MET}} / \mathrm{Crd}_{\mathrm{MET}}+\mathrm{Kfs}+\text { melt }
$$

The lack of metamorphic garnet and cordierite in the exposed migmatitic gneiss of Cerro Asperecito (in which the Peñón Rosado granite was emplaced) suggests that the parental magma was derived from unexposed metamorphic basement.

Table 5

$\mathrm{Rb}-\mathrm{Sr}$ and $\mathrm{Sm}-\mathrm{Nd}$ data for different facies in Peñón Rosado granite

\begin{tabular}{|c|c|c|c|c|c|c|c|c|c|c|}
\hline & $\mathrm{SiO}_{2}($ wt. $\%)$ & \multicolumn{2}{|c|}{ Age (Ma) } & $\mathrm{Rb}$ & $\mathrm{Sr}$ & ${ }^{86} \mathrm{Rb} /{ }^{87} \mathrm{Sr}$ & \multicolumn{2}{|c|}{$\left({ }^{87} \mathrm{Sr} /{ }^{86} \mathrm{Sr}\right)_{\text {today }}$} & $\left({ }^{87} \mathrm{Sr} /{ }^{86} \mathrm{Sr}\right) t$ & $\varepsilon \operatorname{Sr}(t)$ \\
\hline \multicolumn{11}{|c|}{ Peñón Rosado granite $(t=469 \mathrm{Ma})$} \\
\hline PRG1 (VCA-7079) & 65.70 & \multicolumn{2}{|l|}{469} & 49 & 248 & 0.5720 & \multicolumn{2}{|c|}{0.714749} & 0.710926 & 99.12 \\
\hline PRG2 (ASP-108) & 70.40 & \multicolumn{2}{|l|}{469} & 73 & 214 & 0.9877 & \multicolumn{2}{|c|}{0.715628} & 0.709027 & 72.15 \\
\hline PRG2 (ASP-114) & 70.80 & 469 & & 82 & 200 & 1.1872 & \multicolumn{2}{|c|}{0.716072} & 0.708138 & 59.52 \\
\hline \multirow[t]{2}{*}{ LFD (ASP-112) } & 74.57 & 469 & & 41 & 126 & 0.9423 & \multicolumn{2}{|c|}{0.716429} & 0.710132 & 87.84 \\
\hline & $\mathrm{SiO}_{2}$ (wt.\%) & Age (Ma) & $\mathrm{Sm}$ & $\mathrm{Nd}$ & ${ }^{147} \mathrm{Sm} /{ }^{144} \mathrm{Nd}$ & $\left({ }^{143} \mathrm{Nd} /{ }^{144}\right.$ & oday & $\left({ }^{143} \mathrm{Nd} /{ }^{144} \mathrm{Nd}\right) t$ & $\varepsilon \mathrm{Nd}(t)$ & $T_{\mathrm{DM}} *(\mathrm{Ga})$ \\
\hline \multicolumn{11}{|c|}{ Peñón Rosado granite $(t=469 \mathrm{Ma})$} \\
\hline PRG1 (VCA-7079) & 65.70 & 469 & 2.0 & 11.0 & 0.1088 & 0.512068 & & 0.511733 & -5.9 & 1.65 \\
\hline PRG2 (ASP-108) & 70.40 & 469 & 5.6 & 29.4 & 0.1158 & 0.512104 & & 0.511747 & -5.6 & 1.63 \\
\hline PRG2 (ASP-114) & 70.80 & 469 & 6.1 & 30.2 & 0.1211 & 0.512148 & & 0.511776 & -5.0 & 1.59 \\
\hline LFD (ASP-112) & 74.57 & 469 & 1.0 & 4.5 & 0.1337 & 0.512169 & & 0.511758 & -5.4 & 1.62 \\
\hline
\end{tabular}

The decay constants used in the calculations are the values $\lambda^{87} \mathrm{Rb}=1.42 \times 10^{-11}$ and $\lambda^{147} \mathrm{Sm}=6.54 \times 10^{-12}$ year ${ }^{-1}$ recommended by the IUGS Subcommision for Geochronology (Steiger and Jäger, 1977). Epsilon-Sr $(\varepsilon \mathrm{Sr})$ values were calculated relative to a uniform reservoir present day: $\left({ }^{86} \mathrm{Rb}{ }^{87} \mathrm{Sr}\right)^{\text {today }} \mathrm{UR}=0.0827$; $\left({ }^{87} \mathrm{Sr} /{ }^{86} \mathrm{Sr}\right)^{\text {today }}{ }_{\mathrm{UR}}=0.7045$. Epsilon-Nd $(\varepsilon \mathrm{Nd})$ values were calculated relative to a chondrite present day: $\left({ }^{143} \mathrm{Nd} /{ }^{144} \mathrm{Nd}\right)^{\text {today }} \mathrm{CHUR}=0.512638$; $\left({ }^{143} \mathrm{Sm} /{ }^{144} \mathrm{Nd}\right){ }^{\text {today }}{ }_{\mathrm{CHUR}}=0.1967$.

$t=$ time used for the calculation of the isotopic initial ratios. $T_{\mathrm{DM}}{ }^{*}=$ calculated according to DePaolo et al. (1991). PRG=Peñón Rosado granite. The numbers indicating facies 1 and 2 . $\mathrm{LFD}=$ late felsic dykes. 
Table 6

Results of fractional crystallization model for the Peñón Rosado granite

\begin{tabular}{|c|c|c|c|}
\hline $\begin{array}{l}\text { Calculated weight fractions }(\%) \text { in the } \\
\text { parental magma }\end{array}$ & $\begin{array}{l}\text { Calculated extracted phases in the early } \\
\text { crystallized (modal \%) }\end{array}$ & $\begin{array}{l}\text { Minerals utilized in the calculation } \\
(\text { VCA-7079) })^{\mathrm{a}}\end{array}$ & $\begin{array}{l}\text { Modal values from } \\
\text { VCA- } 7079^{\mathrm{b}}\end{array}$ \\
\hline 26.10 & 58.70 & Plagioclase & Plagioclase $\ldots \ldots . . .64 .20 \%$ \\
\hline 12.20 & 27.50 & Quartz & Quartz..........24.90\% \\
\hline 4.20 & 9.50 & Biotite & Biotite...............40\% \\
\hline 1.10 & 2.30 & Muscovite & White mica.......2.20\% \\
\hline 0.80 & 2.00 & Garnet & Garnet................1.80\% \\
\hline
\end{tabular}

\begin{tabular}{|c|c|c|c|c|c|c|c|c|c|c|}
\hline & $\mathrm{SiO}_{2}$ & $\mathrm{TiO}_{2}$ & $\mathrm{Al}_{2} \mathrm{O}_{3}$ & $\mathrm{FeO}^{\text {total }}$ & $\mathrm{MnO}$ & $\mathrm{MgO}$ & $\mathrm{CaO}$ & $\mathrm{Na}_{2} \mathrm{O}$ & $\mathrm{K}_{2} \mathrm{O}$ & $\mathrm{P}_{2} \mathrm{O}_{5}$ \\
\hline \multicolumn{11}{|c|}{ Weight fractions (\%) of magma remaining with a composition equal to PRG2 (daughter magma) $=55.3$} \\
\hline Parental magma ${ }^{\mathrm{c}}$ & 69.33 & 0.26 & 16.07 & 2.74 & 0.21 & 0.94 & 3.68 & 3.93 & 1.67 & 0.11 \\
\hline Determined parental magma & 70.07 & 0.26 & 16.24 & 2.77 & 0.21 & 0.95 & 3.72 & 3.97 & 1.69 & 0.11 \\
\hline \multirow{2}{*}{ Calculated parental magma } & 70.07 & 0.27 & 16.25 & 2.76 & 0.22 & 0.99 & 3.74 & 3.93 & 1.67 & 0.07 \\
\hline & 0.00 & -0.01 & -0.01 & 0.02 & -0.01 & -0.04 & -0.02 & 0.05 & 0.02 & 0.05 \\
\hline \multicolumn{11}{|l|}{$\Sigma R^{2}=0.007$} \\
\hline Early crystallized (VCA-7079) & 65.70 & 0.20 & 18.95 & 2.44 & 0.44 & 0.84 & 4.11 & 5.32 & 1.10 & 0.05 \\
\hline Early crystallized (calculated) ${ }^{\mathrm{d}}$ & 67.03 & 0.24 & 17.52 & 2.48 & 0.33 & 0.91 & 3.97 & 4.60 & 1.32 & nd \\
\hline
\end{tabular}

Determined and calculated parental magma compositions were obtained using IGPET program (Carr, 1998). This program makes fractional crystallization calculations using least-squares regression of the major elements, after Bryan et al. (1969).

$\Sigma R^{2}=$ sum of the squares of the residuals.

${ }^{\text {a }}$ Mineral chemistry in Table 2. The samples are: plagioclase average with $n=4$, garnet average with $n=7$, biotite average with $n=4$, white mica average with $n=5$ and quartz (one analyses): $\mathrm{SiO}_{2}=98.26 \%, \mathrm{FeO}=0.03 \%, \mathrm{Na}_{2} \mathrm{O}=0.01 \%, \mathrm{~K}_{2} \mathrm{O}=0.03 \%$.

b Modal proportions in Table 1.

${ }^{c}$ Daughter magma is the resulted of the average between ASP-108, ASP-114, and ASP-216 (PRG2); parental magma is derived from simple mixing of early crystallized (30\% VCA-7079, PRG1) and daughter magma (70\%, PRG2), and early crystallized is represented by VCA-7079. All data in Table 3.

d $\Sigma$ (proportion modal $\times$ mineral chemistry used in the calculation).

The petrological and geochemical evidence indicates that the appearance of garnet in Peñón Rosado granite result of the direct nucleation and subsequent crystallization from the peraluminous magma, as indicated by other authors for garnet crystallizad in felsic granites (e.g., Clarke, 1981; du Bray, 1988; Harrison, 1988; Kebede et al., 2001). Therefore, the reaction most probable for garnet crystallization is (Fig. 11)

Magma $\rightarrow \mathrm{Grt}_{\mathrm{MAG}}+$ Other Solid Phases.

The compositional data and the physical conditions of crystallization reported in this work for solid phases such as biotite or white mica (see also below) are consistent with magmatic equilibration with garnet.

The whole-rock geochemistry (Table 3 ) shows that the $\mathrm{MnO} /(\mathrm{FeO}+\mathrm{MnO}+\mathrm{MgO})$ ratios decrease from PRG1 $(\mathrm{VCA}-7079=0.12 \%)$ to PRG2 (ASP$114=0.03 \%$ ), but increase again during the crystallization of PRG3 (ASP-111=0.1\%), reaching their highest values in the late felsic dykes (ASP$112=0.23 \%$ ). Sympathetically, PRG garnets have the following $\mathrm{Mn} /(\mathrm{Fe}+\mathrm{Mn}+\mathrm{Mg}$ ) ratios (Table 2c): VCA$7079=0.37$, ASP-114 $=0.25$, ASP-11 $=0.40$; and ASP$112=0.38$. Thus fractionation of $\mathrm{Mn}$ in garnet as well as the proportion of garnet that crystallizes (Table 1) is roughly controlled by the evolving composition of the different granitic facies.

The consistently high $\mathrm{Al}^{\mathrm{IV}}$ in the biotites of all facies of the Peñón Rosado granite strongly suggests that their alumina contents were buffered by equilibration with an Al-rich phase, probably under constant temperature and pressure conditions, and the presence of garnet and primary white mica is consistent with a relatively $\mathrm{Al}_{2} \mathrm{O}_{3}$ enriched magma. Dahlquist et al. (2005b) and Clarke et al. (2005) report comparable $\mathrm{Al}^{\mathrm{IV}}$ contents in biotites for other peraluminous rocks with magmatic cordierite or andalusite (Table 2d). The biotites have high $\mathrm{Fe}^{2+} /\left(\mathrm{Fe}^{2+}+\mathrm{Mg}\right)$ ratios, except for those in the more differentiated facies such as PRG3, suggesting that the Fe was consumed during earlier crystallization. Remarkably, the early-crystallized PRG1 biotites have higher $\mathrm{MnO}$ contents $(0.72$ to $1.12 \%$, Table $2 \mathrm{~d})$. Miller and Stoddard (1981) affirm that biotites coexisting with garnets have higher $\mathrm{MnO}>0.75 \%$, than the 0.2 to $0.5 \%$ typical of igneous biotites without coexisting garnet. The lower MnO content for PRG2 and PRG3 biotites results from scavenging of $\mathrm{MnO}$ by the biotites and garnets crystallizing in PRG1. 
Table 7

Data used in the fractional crystallization mathematical model for the Peñón Rosado granite

\begin{tabular}{|c|c|c|c|c|c|c|c|c|c|c|c|}
\hline Minerals & $\begin{array}{l}\text { Modal proportion } \\
\text { (VCA-7079) }\end{array}$ & $\begin{array}{l}K_{\mathrm{d}}^{\mathrm{S} / \mathrm{L}} \\
(\mathrm{La})\end{array}$ & $\begin{array}{l}K_{\mathrm{d}}^{\mathrm{S} / \mathrm{L}} \\
(\mathrm{Ce})\end{array}$ & $\begin{array}{l}K_{\mathrm{d}}^{\mathrm{S} / \mathrm{L}} \\
(\mathrm{Nd})\end{array}$ & $\begin{array}{l}K_{\mathrm{d}}^{\mathrm{S} / \mathrm{L}} \\
(\mathrm{Sm})\end{array}$ & $\begin{array}{l}K_{\mathrm{d}}^{\mathrm{S} / \mathrm{L}} \\
(\mathrm{Eu})\end{array}$ & $\begin{array}{l}K_{\mathrm{d}}^{\mathrm{S} / \mathrm{L}} \\
(\mathrm{Gd})\end{array}$ & $\begin{array}{l}K_{\mathrm{d}}^{\mathrm{S} / \mathrm{L}} \\
(\mathrm{Tb})\end{array}$ & $\begin{array}{l}K_{\mathrm{d}}^{\mathrm{S} / \mathrm{L}} \\
(\mathrm{Dy})\end{array}$ & $\begin{array}{l}K_{\mathrm{d}}^{\mathrm{S} / \mathrm{L}} \\
(\mathrm{Yb})\end{array}$ & $\begin{array}{l}K_{\mathrm{d}}^{\mathrm{S} / \mathrm{L}} \\
(\mathrm{Lu})\end{array}$ \\
\hline Pl & 0.642 & $0.30^{+}$ & $0.35^{-}$ & $0.29^{\#}$ & $0.34^{-}$ & $1.11^{@}$ & $0.13^{\#}$ & $0.14^{+}$ & $0.13^{+}$ & $0.08 *$ & $0.06^{*}$ \\
\hline Qtz* & 0.249 & 0.02 & 0.01 & 0.02 & 0.01 & 0.06 & 0.02 & 0.02 & 0.02 & 0.02 & 0.01 \\
\hline $\mathrm{Bt}^{+}$ & 0.054 & 7.93 & 5.93 & 3.30 & 2.65 & 2.65 & 2.52 & 2.39 & 2.08 & 1.80 & 2.00 \\
\hline $\mathrm{Ms}^{\wedge}$ & 0.022 & 6.04 & 7.11 & 10.81 & 6.72 & 1.89 & 4.19 & 5.50 & 2.97 & 7.25 & 7.74 \\
\hline Grt* & 0.018 & 0.39 & 0.70 & 0.60 & 2.70 & 0.52 & 10.50 & 11.90 & 28.60 & 43.48 & 39.78 \\
\hline \multirow[t]{2}{*}{ Zrn* } & 0.003 & 16.90 & 16.75 & 13.30 & 14.40 & 16.0 & 12.00 & 37.00 & 47.40 & 191.00 & 264.50 \\
\hline & & $\mathrm{La}$ & $\mathrm{Ce}$ & $\mathrm{Nd}$ & $\mathrm{Sm}$ & $\mathrm{Eu}$ & $\mathrm{Gd}$ & $\mathrm{Tb}$ & Dy & $\mathrm{Yb}$ & $\mathrm{Lu}$ \\
\hline \multicolumn{2}{|l|}{$\mathrm{C}_{\mathrm{o}}$} & 31.44 & 64.38 & 24.16 & 4.68 & 1.16 & 3.86 & 0.67 & 3.95 & 3.56 & 0.61 \\
\hline \multicolumn{12}{|c|}{ Results obtained from the fractional crystallization mathematical model $C_{L}^{i}$ (concentration in ppm) } \\
\hline \multicolumn{2}{|c|}{ 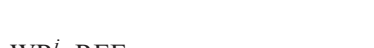 } & $\mathrm{La}$ & $\mathrm{Ce}$ & $\mathrm{Nd}$ & Sm & $\mathrm{Eu}$ & Gd & $\mathrm{Tb}$ & Dy & $\mathrm{Yb}$ & $\mathrm{Lu}$ \\
\hline \multicolumn{2}{|c|}{$\mathrm{WR}_{\mathrm{L}}^{i} \mathrm{REE}$} & 31.93 & 65.27 & 25.80 & 5.09 & 1.11 & 4.36 & 0.72 & 4.03 & 2.57 & 0.41 \\
\hline \multicolumn{2}{|c|}{ Calculated liquid $C_{\mathrm{L}}^{i} \mathrm{REE}$} & 31.73 & 65.18 & 26.22 & 5.40 & 1.16 & 4.62 & 0.76 & 4.03 & 2.53 & 0.39 \\
\hline \multicolumn{2}{|c|}{$\mathrm{WR}_{\mathrm{S}}^{i} \mathrm{REE}$} & 17.40 & 36.80 & 11.00 & 1.98 & 1.10 & 152 & 0.40 & 3.83 & 6.54 & 1.16 \\
\hline \multicolumn{2}{|c|}{ Calculated solid $C_{\mathrm{S}}^{i} \mathrm{REE}$} & 25.07 & 50.04 & 17.22 & 3.04 & 1.07 & 2.5 & 0.5 & 3.70 & 4.21 & 0.71 \\
\hline
\end{tabular}

Equation describing fractional crystallization is the equation for Rayleigh fractionation: $C_{\mathrm{L}}^{i}=C_{0} \cdot F^{(D-1)}$.

$C_{0}$ : the weight concentration in the parental melt is a mixing from 30\% PRG1 cumulate (VCA-7079) and 70\% of fractionated melt PRG2 (ASP-108, ASP-114, and ASP-216 average). Data in Table 3.

$D=$ bulk distribution coefficient of the fractionating assemblage during crystal fractionation $=\Sigma X \times K_{\mathrm{d}}^{\mathrm{S} / \mathrm{L}}$, where $X$ is the mineral proportion crystallizing from the parental magma, and $K_{\mathrm{d}}^{\mathrm{S} / \mathrm{L}}$ is the solid-liquid partition coefficient of phase $i$. $X=$ modal proportions of VCA-7079 (Table 1). $F=$ weight fraction of melt produced in fractional crystallization. $F$ is 0.55 .

$\mathrm{WR}_{\mathrm{L}} i=$ whole-rock liquid is the average composition of the PRG2 facies. Data in Table 3 .

$C_{\mathrm{L}}^{i}=$ weight concentration of a trace element " $i$ " in the fractionated melt.

$\mathrm{WR}_{\mathrm{S}} i=$ whole-rock solid is the composition of VCA-7079 (PRG1 facies). Data in Table 3.

$C_{\mathrm{S}}^{i}=$ weight concentration of a trace element " $i$ " in cumulate crystallized.

The partition coefficient for granitic liquids: data from *Rollinson (1993, Table 4.1), ${ }^{+}$Nash and Crecraft (1985), ^du Bray (1994),-Nagasawa and Schnetzler (1971), ${ }^{@}$ Fujimaki et al. (1984), and ${ }^{\#}$ Arth (1976).

The petrographic and compositional characteristics of some of the Fe-rich white mica in the Peñón Rosado granite (Fig. 6) indicate a magmatic origin (Miller et al., 1981; Clarke et al., 2005; Dahlquist et al., 2005b) and are therefore indicative of a parental peraluminous magma.

The patchy zoning of PRG1 plagioclases is interpreted as due to resorption of early growth and infilling of the corroded regions by more sodic material (Vance, 1962; Anderson, 1984). This is consistent (together with the field evidence and textural characteristics of the microcline described in Sections 3.2 and 3.3 respectively) with the assumption that PRG1 is an older, plagioclase-rich facies, segregated early from the parental magma and reheated during intrusion of the later facies. The oscillatory compositional zoning of plagioclase in PRG3 and late felsic dykes may indicate final shallow crystallization with cyclic changes in temperature and pressure accompanying convective overturn. Alkali feldspar is only conspicuously present in PRG3, strongly suggesting that this facies is a residual melt saturated in $\mathrm{K}_{2} \mathrm{O}$, whereas its absence in late felsic dykes suggests that $\mathrm{K}_{2} \mathrm{O}$ was mostly consumed during the earlier PRG3 crystallization.

\subsection{Interpretation from whole-rock geochemical data}

Major element geochemical data indicate that the PRG2 facies represents a differentiated melt from a parental magma due to removal of material in PRG1. The latter facies has higher $\mathrm{Al}_{2} \mathrm{O}_{3}, \mathrm{CaO}, \mathrm{Na}_{2} \mathrm{O}, \mathrm{MnO}$ and lower $\mathrm{FeO}^{\mathrm{t}}, \mathrm{MgO}, \mathrm{TiO}_{2}, \mathrm{P}_{2} \mathrm{O}_{5}$ contents, consistent with plagioclase accumulation and crystallization of garnet with minor biotite-muscovite and apatite. PRG2 has higher $\mathrm{FeO}^{\mathrm{t}}, \mathrm{MgO}, \mathrm{TiO}_{2}, \mathrm{~K}_{2} \mathrm{O}$, and $\mathrm{P}_{2} \mathrm{O}_{5}$ consistent with crystallization of biotite along with muscovite, apatite, and felsic minerals. This facies represents a compositional inflexion between PRG1 and PRG3, strongly suggesting the onset of crystallization of a new assemblage mineral. The fractional crystallization model supports a parental magma represented by a mixture 30\% PRG1 and 70\% PRG2, where PRG1 and PRG2 are early crystallized and differentiated melt respectively. PRG3 represents a late residual melt after total crystallization of the PRG2 facies, and is depleted in major oxides except for $\mathrm{MnO}$ and $\mathrm{K}_{2} \mathrm{O}$. Sample ASP112 is a late felsic dyke with plagioclase and garnet; the absence of alkali feldspar indicates that the $\mathrm{K}_{2} \mathrm{O}$ was consumed in PRG3. 
Table 8

Geothermobarometry for Peñón Rosado granite

Peñón Rosado granite, PRG1 facies, sample VCA-7079

\begin{tabular}{|c|c|c|c|}
\hline \multirow[t]{2}{*}{ Calibration } & \multirow{2}{*}{$\begin{array}{l}\text { Mineral assemblage/Zr } \\
\text { concentration }(\mathrm{ppm})\end{array}$} & \multicolumn{2}{|c|}{ Geothermobarometry } \\
\hline & & Temperature $\left({ }^{\circ} \mathrm{C}\right)$ & Pressure (kbar) \\
\hline Ganguly and Saxena (1984) & Garnet-biotite & $784^{\mathrm{a}}$ & \\
\hline Hoisch (1990) R2 model & Garnet-biotite-plagioclase-quartz & & $5.9 \pm 0.1$ \\
\hline TWQ Berman $(1991)^{\mathrm{b}}$ & Garnet-biotite & 792 & 6.0 \\
\hline Zircon saturation temperature $\left(T_{\mathrm{Zr}}\right)^{\mathrm{c}}$ & $117^{\mathrm{d}}$ & 764 & \\
\hline
\end{tabular}

$T-P$ calculated by interaction. Temperature values calculated according to the calibrations of Ganguly and Saxena (1984) are calculated until it satisfies the pressure obtained according to the calibration of Hoisch (1990).

Garnet composition from the average of 7 analysis: $n=7$, central zone of Grt $_{\mathrm{a}}$ (Table 2c).

Biotite composition from the average of 4 analysis: $n=4$, Table $2 \mathrm{~d}$.

White mica composition from the average of 4 analysis: $n=4$, Table 2e.

Plagioclase composition from the average of 4 analysis: $n=4$, Table 2a.

a See uncertainty discussion in Ganguly and Saxena (1984) and Anderson (1996).

b Activity-composition model for garnet from Berman (1990) and biotite from McMullin et al. (1991).

c $T_{\mathrm{Zr}}=12,900 /\left[2.95+0.85 M+\ln \left(476,000 / \mathrm{Zr}_{\text {melt }}\right)\right]$, where $D^{\mathrm{Zr} \text {,zircon/melt }}=\left(476,000 / \mathrm{Zr}_{\text {melt }}\right)$, is the ratio of $\mathrm{Zr}$ concentrations (ppm) in zircon to that in the saturated melt; $M$ is a compositional factor that accounts for dependence of zircon solubility on $\mathrm{SiO}_{2}$ and peraluminosity of the melt $[(\mathrm{Na}+\mathrm{K}+$ $2 \cdot \mathrm{Ca}) / \mathrm{Al} \cdot \mathrm{Si})$, all in cation fraction]. Equation and $\mathrm{Zr}$ concentrations $(\mathrm{ppm})$ in zircon $(=476,000 \mathrm{ppm})$ from Miller et al. (2003).

d Zirconium concentration from VCA-7079 (PRG1 facies), Table 3.

Trace element concentrations in the different facies are coherent with the interpretations obtained from the major oxides. Thus, the change from low Ba in PRG1 to higher Ba in PRG2 (Fig. 8) indicates the onset of biotite and muscovite crystallization, whereas the distinct compositional change between PRG2 and PRG3 supports a new fractionation trends resulting in abundant alkali feldspar crystallization (McCarthy and Robb, 1978; Rapela and Shaw, 1979), where ASP-215 $(\mathrm{Ba}=601 \mathrm{ppm})$ is the first and ASP-111 $(\mathrm{Ba}=170 \mathrm{ppm})$ is the last crystallized. $\mathrm{Rb}$, a typical incompatible element concentrated in residual melts, reaches its highest concentration in PRG3. The high Sr content in PRG1 is coherent with the accumulation of plagioclase in this facies, and $\mathrm{Sr}$ contents decrease with differentiation from PRG1 to PRG3. Zr content varies little between PRG1 and PRG2, but

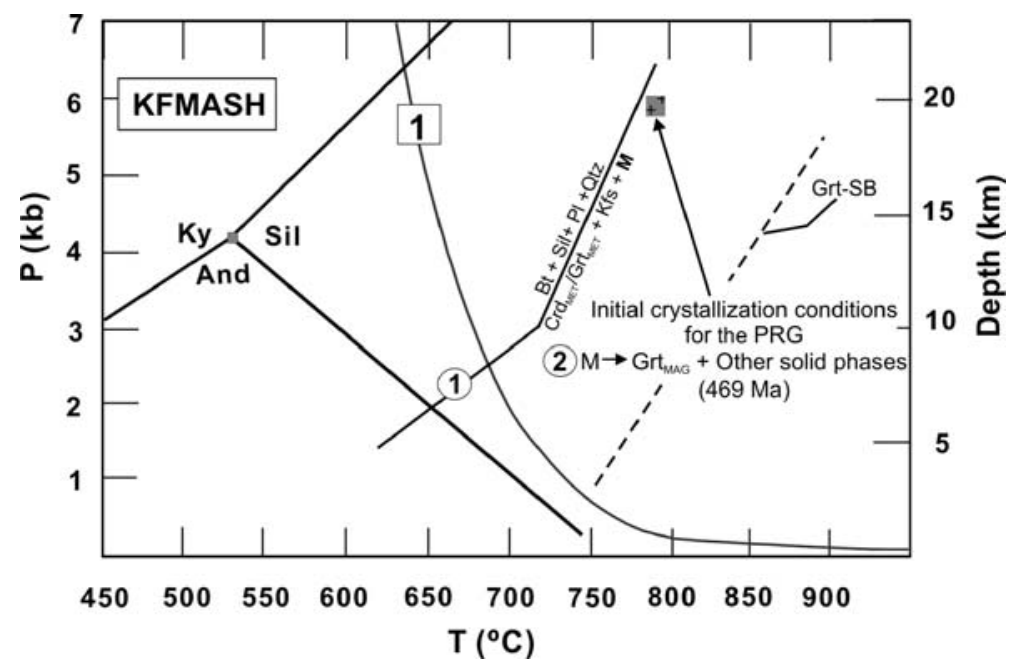

Fig. 11. Simplified $P-T$ grid showing conditions of metamorphism and melt generation for the Peñon Rosado granite together with selected univariant reactions. Reaction 1 in the KFMASH system from Pattison and Tracy (1991) and Vernon et al. (2001). Grt-SB: stability boundary for garnet according to Clemens and Wall (1981). $\mathrm{Al}_{2} \mathrm{SiO}_{5}$ phase relations according to Guowei et al. (1994). Triple point $\left(530{ }^{\circ} \mathrm{C} \pm 20{ }^{\circ} \mathrm{C}\right.$ and $\left.4.2 \mathrm{~kb} \pm 0.3 \mathrm{~kb}\right)$ according to Bohlen et al. (1991). Square '1', haplogranitic water-saturated solidus. Reaction 2 for garnet crystallization is discussed in the text. Bt=biotite, $\mathrm{Sil}=$ sillimanite, $\mathrm{Qtz}=$ quartz, $\mathrm{Crd}=$ cordierite, $\mathrm{Grt}=$ garnet, $\mathrm{Kfs}=$ alkali feldspar, And=andalusite, $\mathrm{Ky}=\mathrm{kyanite}, \mathrm{M}=\mathrm{melt}, \mathrm{MAG}=\mathrm{magmatic}$, MET $=$ metamorphic. 
decreases abruptly between PRG2 and PRG3, suggesting little crystallization of zircon in the residual melt.

Sawyer (1987), using mathematical modelling, suggested that REE patterns in different layers of migmatites may help to distinguish whether leucosomes represent pure melts or segregated cumulates. In addition, Johannes et al. (2003) have investigated metasedimentary migmatite and related small-scale Stype granites and conclude that the chemical signature (e.g., REE patterns) can distinguish between felsic cumulates (represented by leucosome in migmatite) and differentiated or primary melts (represented by Stype granites). The PRG2 facies has relatively high REE contents and negative Eu-anomalies (Fig. 12), similar to rocks interpreted as melt derived from migmatites, whereas PRG1 has relatively low REE and positive Eu-anomalies, as in the corresponding cumulate material (Sawyer, 1987; Johannes et al., 2003). Thus, chemical signature and the fractional crystallization model (using REE and major oxides) are fully consistent with a fractional crystallization process where PRG1 represent a felsic cumulate and PRG2 a differentiated melt.

Geochemical characteristics and isotopic ratios (Table 5) are consistent with derivation of the Peñón Rosado granite by partial melting of the metasedimentary rocks. Sylvester (1998) argued that the $\mathrm{CaO} / \mathrm{Na}_{2} \mathrm{O}$ ratios in S-type peraluminous granitoids are controlled by the original proportion of plagioclase in the source rock. Thus, S-type peraluminous melts produced from clay-rich sources (plagioclase-poor) tend to have lower $\mathrm{CaO} / \mathrm{Na}_{2} \mathrm{O}$ ratios $(<0.3)$ than melts derived from sources which are clay-poor (plagioclase-rich, $\mathrm{CaO} / \mathrm{Na}_{2} \mathrm{O}$ ratios $>0.3$ ). The $\mathrm{CaO} / \mathrm{Na}_{2} \mathrm{O}$ of 1.04 for the assumed parental melt of the Peñón Rosado granite (Table 6), together with the discrimination diagram of Sylvester (1998), indicates a clay-poor source such as metagreywacke (Fig. 13).

The $\mathrm{CaO} \%$ content of the inferred parental melt is remarkably high (3.68\%, Table 6). Experimental dehydration melting of metagreywacke (Patiño Douce and Beard, 1996) produced melts with $\mathrm{CaO}=0.73 \%$ to $1.67 \%$. However, because increasing $\mathrm{H}_{2} \mathrm{O}$ activity depresses the plagioclase + quartz solidus more strongly than it depresses the stability of micas (Patiño Douce, 1996; Patiño Douce and Harris, 1998), $\mathrm{H}_{2} \mathrm{O}$-fluxed melting consumes plagioclase more effectively than micas, increasing the $\mathrm{CaO}$ and the $\mathrm{Na}_{2} \mathrm{O}$ in the melt. In agreement with this, Holtz and Johannes (1991) determined that with increasing amounts of $\mathrm{H}_{2} \mathrm{O}$ the melt becomes richer in $\mathrm{CaO}, \mathrm{FeO}$ and $\mathrm{Na}_{2} \mathrm{O}$ and poorer in $\mathrm{K}_{2} \mathrm{O}$, and that $\mathrm{CaO} / \mathrm{Na}_{2} \mathrm{O}$ ratios increase progressively. These experimental data explain the high $\mathrm{CaO} / \mathrm{Na}_{2} \mathrm{O}$ ratios and low $\mathrm{K}_{2} \mathrm{O}$ content in the hypothetical parental magma. Among dehydration reactions (e.g., Vielzeuf and Holloway, 1988; Patiño Douce and Harris, 1998) only muscovite may undergo substantial dehydration at $T<800{ }^{\circ} \mathrm{C}$ (Miller et al., 2003), and in consequence

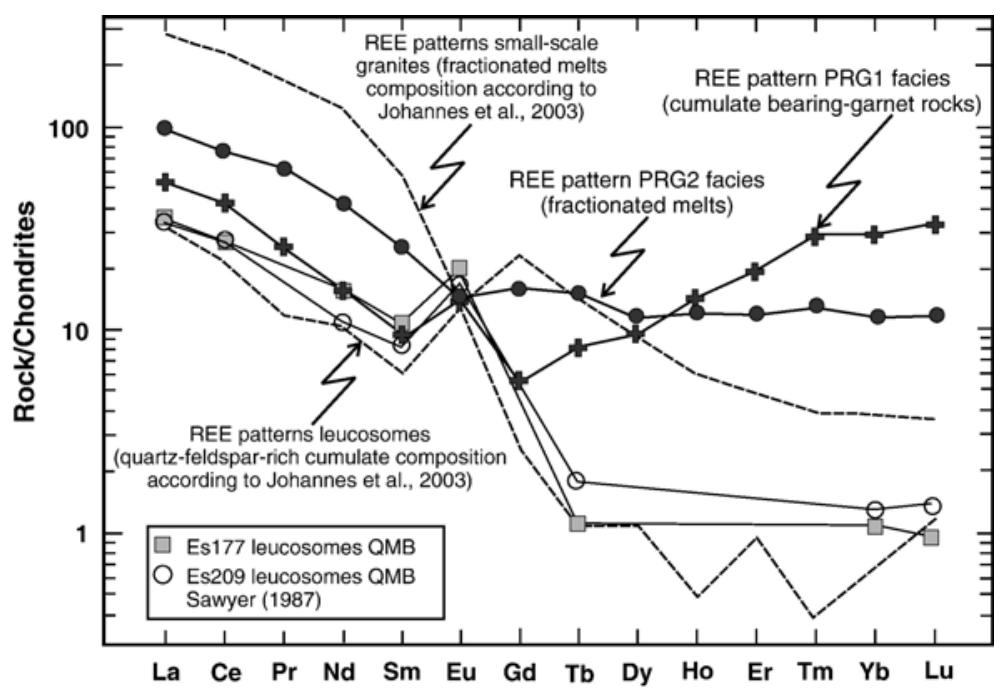

Fig. 12. Modified from Johannes et al. (2003, Fig. 12). Upper broken line is the REE pattern for small-scale granites from Turku, Finland, interpreted as fractionated from a primary undifferentiated melt derived by partial melting of metasedimentary migmatites during the metamorphic peak $\left(830{ }^{\circ} \mathrm{C}\right.$ and $6 \mathrm{kbar}$; cordierite, garnet and partial melt are the most important reaction products). Lower broken line is the REE pattern of leucosomes in migmatites from Turku, which are interpreted as cumulates segregated from the primary melt. The low normalized Tm and Ho values are due to analytical uncertainties (Johannes et al., 2003). Other REE patterns of the migmatite leucosomes interpreted as cumulates are from Sawyer (1987). Solid line and full black circles and crosses define the REE pattern for the PRG1 and PRG2 facies. 


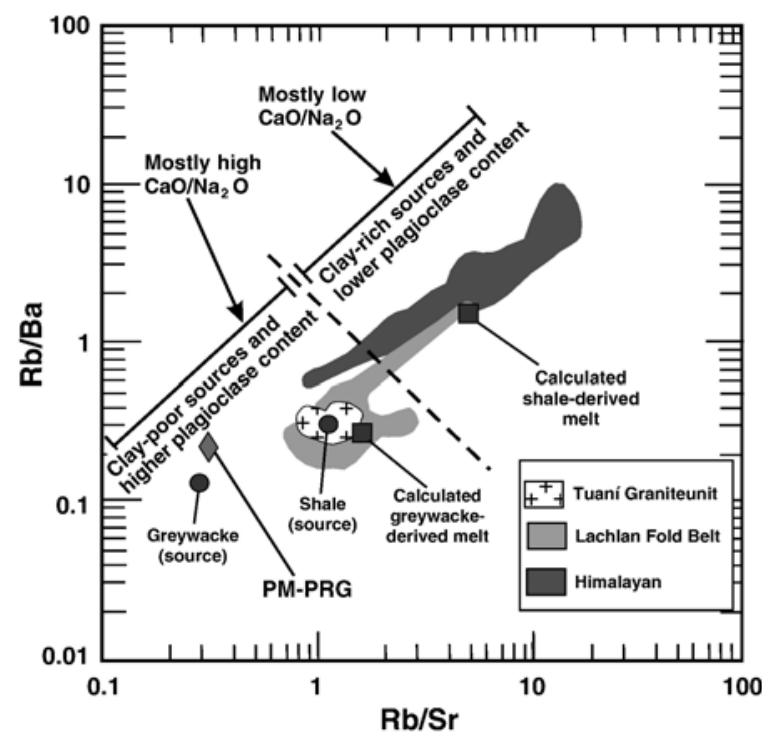

Fig. 13. $\mathrm{Rb} / \mathrm{Sr}$ vs. $\mathrm{Rb} / \mathrm{Ba}$ diagram for strongly peraluminous granitoids modified from Sylvester (1998). The dark fields, discontinuous line, and calculated melt are from Fig. 7 of Sylvester (1998). Geochemical data of the Tuaní Granite unit (cordierite-bearing granitoids) in the Sierra de Chepes from Dahlquist et al. (2005b). PM-PRG=composition of the assumed parental magma for the Peñón Rosado granite.

muscovite must be abundant (e.g., pelitic source) for this to result in anatexis. However, the composition of the parental magma of Peñon Rosado granite is not consistent with a pelitic source, and it is more probably a result of $\mathrm{H}_{2} \mathrm{O}$-fluxed melting of metagreywacke. The crystallization of the Peñón Rosado granite (469 Ma) was almost synchronous with that of a major metaluminous suite emplaced during the Middle Ordovician (468 Ma; Pankhurst et al., 2000) in similar $P-T$ conditions (Dahlquist et al., 2006), suggesting that the latter may have been the cause of anatexis of the surrounding metasediments. The small exposed area of the Peñon Rosado granite (only $\sim 5 \%$ at Cerro Asperecito) relative to the metaluminous granitoids outcrops in this region implies that heat input from a major batholith was required in order to generate a small amount of peraluminous magma.

\section{Conclusions}

All available data, including field and petrographic relationships, mineral chemistry, bulk major and trace element compositions, and isotopic ratios support differentiation by fractional crystallization in the middle crust, including the crystallization of magmatic garnet. The crystallization sequence has three main stages represented by the PRG1, PRG2 and PRG3 facies: PRG1 represents a plagioclase-rich cumulate, PRG2 a differentiated melt, and PRG3 a late residual melt. Mineral assemblages are $\mathrm{Pl}$ and subordinate Qtz, Grt, Bt and Ms in PRG1, P1, Ms, Grt, Qtz \pm Kfs and major Bt in PRG2, and conspicuous Kfs in PRG3. Remarkably, garnet crystallized throughout the differentiation sequence of the Peñón Rosado granite $\left(\mathrm{SiO}_{2}=65.70-74.57 \%\right)$. Its textural characteristics and chemical compositions indicate that it could have formed by direct nucleation and subsequent crystallization from the peraluminous magma in equilibrium with solid phases such as biotite and white mica. Fractionation of $\mathrm{Mn}$ in garnet as well as the proportion of garnet that crystallizes is roughly controlled by the evolving composition of the different granitic facies. Based in our garnet studies we confirm the finding of previous garnet studies from metamorphic and felsic granites, that the zoning in garnet is strongly temperature-dependent. At magmatic temperatures above $\sim 700{ }^{\circ} \mathrm{C}$, the diffusion becomes sufficiently rapid to eliminate compositional zoning, typically producing spessartine-almandine garnets that are unzoned or have "spessartine inverse bell-shaped profiles". Contrarily, garnet housed in granitic rocks, but exhibiting "spessartine bell-shaped profile" must be considered of metamorphic origin (i.e., xenocrystic), or formed in very felsic magmas $\left(\mathrm{SiO}_{2}=73-76 \%\right)$ crystallizing below $\sim 700{ }^{\circ} \mathrm{C}$. In these cases geothermobarometric calculation is dangerous and should be used with caution.

The parental magma of the Peñón Rosado granite was derived from a plagioclase-rich metasedimentary source (metagreywacke) in the middle crust ( 19-20 km) under moderate-low magmatic temperature conditions. The parental magma resulted from $\mathrm{H}_{2} \mathrm{O}$-fluxed melting of metagreywacke, with the heat input coming from a major metaluminous suite that caused local anatexis of the surrounding metasediments.

\section{Acknowledgements}

Financial support was provided by IM40 2000 (ANPCyT), BTE2001-1486 (Spain) y PIP02082 CONICET. Juan A. Dahlquist thanks Professor César Casquet and José González del Tánago (UCM) as well as to the technician Alfredo Fernández for their assistance with use of the electron microprobe. The authors thank Professor Edgardo Baldo (CONICETUNC) by the assistance in $P-T$ calculation using TWQ of Berman (1991), Dr. Raúl Lira (CONICET-UNC) by mineralogical discussion, and Professor Calvin Miller by discussion about $T_{\mathrm{Zr}}$ and the occurrence of garnet in igneous rocks. We greatly appreciate the critical comments of two anonymous colleagues and the 
valuable suggestions of the Editor Stephen Foley, that led to improvements in the quality of the work. Juan A. Dahlquist thanks CRILAR for general technical support.

\section{References}

Allan, B.D., Clarke, D.B., 1981. Occurrences and origin of garnets in the South Mountain Batholith, Nova Scotia. Can. Mineral. 19, $19-24$.

Anderson, A.T., 1984. Probable relations between plagioclase zoning and magma dynamics, Fuego Volcano Guatemala. Am. Mineral. 69, 660-676.

Anderson, J.L., 1996. Status of thermobarometry in granitic batholiths. Trans. R. Soc. Edinb. Earth Sci. 87, 125-138.

Atherton, M.P., 1968. The variation in garnet, biotite and chlorite compositions in medium grade pelitic rocks from the Dalradian, Scotland, with particular reference to the zonation in garnet. Contrib. Mineral. Petrol. 18, 347-371.

Arth, J.G., 1976. Behavior of trace elements during magmatic processes - a summary of theoretical models and their applications. J. Res. U.S. Geol. Surv. 4, 41-47.

Barker, F., 1979. Trondhjemite: definition, environment and hypotheses of origin. In: Barker, F. (Ed.), Trondhjemites, Dacites and Related Rock. Elsevier, Amsterdan, pp. 1-12.

Berman, R.G., 1990. Mixing properties of $\mathrm{Ca}-\mathrm{Mg}-\mathrm{Fe}-\mathrm{Mn}$ garnets. Am. Mineral. 75, 328-344.

Berman, R.G., 1991. Thermobarometry using multiequilibrium calculations: a new technique with petrologic applications. Can. Mineral. 29, 833-855.

Bohlen, S.R., Montana, A., Kerrick, D.M., 1991. Precise determinations of equilibria kyanite-sillimanite and kyanite-andalusite and revised triple point for $\mathrm{Al}_{2} \mathrm{SiO}_{5}$ polymorphs. Am. Mineral. 76, 677-680.

Boynton, W.V., 1984. Geochemistry of the rare earth elements: meteorites studies. In: Henderson, P. (Ed.), Rare Earth Element Geochemistry. Elsevier. 63-114 pp.

Bryan, W.B., Finger, L.W., Chayes, F., 1969. Estimating proportions in petrographic mixing equations by least-squares approximation. Science 163, 926-927.

Carr, M.J., 1998. IgPet32 program, Terra Software Inc.

Casquet, C., Baldo, E., Pankhurst, R.J., Rapela, C.W., Galindo, C., Fanning, C.M., Saavedra, J., 2001. Involvement of the Argentine precordillera terrane in the Famatinian moble belt: U-Pb SHRIMP and metamorphic evidence from the Sierra de Pie de Palo. Geology 29, 703-706.

Chappell, B.W., 1997. Compositional variation within granite suites of the Lachlan Fold Blet: its causes and implications for the physical state of granite magma. Trans. R. Soc. Edinb. Earth Sci. 88, 159-170.

Chappell, B.W., White, A.J.R., 1992. I- and S-type granites in the Lachlan Fold Belt. Trans. R. Soc. Edinb. Earth Sci. 83, 1-26.

Clarke, D.B., 1981. The mineralogy of peraluminous granites: a review. Can. Mineral. 19, 3-17.

Clarke, D.B., Dorais, M., Barbarin, B., Barker, D., Cesare, B., Clarke, G., el Baghdadi, M., Erdmann, S., Förster, H.J., Gaeta, M., Gottesmann, B., Jamieson, R.A., Kontak, D.J., Koller, F., Gomes, C.L., London, D., Morgan Vi, G.B., Neves, L.J.P.F., Pattison, D.R.M., Pereira, A.J.S.C., Pichavant, M., Rapela, C.W., Renno, A.D., Richards, S., Roberts, M., Rottura, A., Saavedra, J., Sial, A.N., Toselli, A.J., Ugidos, J.M., Uher, P., Villaseca, C., Visonà, D., Whitney, D.L., Williamson, B., Woodard, H.H., 2005. Occurrence and origin of andalusite in peraluminous felsic igneous rocks. J. Petrol. 46, 441-472.
Clemens, J.D., Wall, V.J., 1981. Origin and crystallization of some peraluminous (S-type) granitic magmas. Can. Mineral. 19, 111-131.

Dahlquist, J.A., 2002. Mafic microgranular enclaves: early segregation from metaluminous magma (Sierra de Chepes), Pampean Ranges, NW Argentina. J. South Am. Earth Sci. 15, 643-655.

Dahlquist, J.A., Galindo, C., 2004. Geoquímica isotópica de los granitoides de la sierra de Chepes: un modelo geotectónico y termal, implicancias para el orógeno famatiniano. Rev. Asoc. Geol. Argent. 59 (1), 57-69.

Dahlquist, J.A., Rapela, C.W., Pankhurst, R.J., Baldo, E., Saavedra, J., Alasino, P.H., 2005a. Los granitoides de la sierra de Chepes y su comparación con granitoides paleozoicos de las Sierras Pampeanas: Implicancias para el orógeno famatiniano. In: Dahlquist, J.A., Baldo, E.G., Alasino, P.H. (Eds.), Geología de la provincia de La Rioja - Precámbrico-Paleozoico Inferior. Asoc. Geol. Argentina, Serie D, Publ. Esp., vol. 8, pp. 87-108.

Dahlquist, J.A., Rapela, C.W., Baldo, E.G., 2005b. Cordieritebearing S-Type granitoids in the Sierra de Chepes (Sierras Pampeanas): petrogenetic implications. J. South Am. Earth Sci. 20, 231-251.

Dahlquist, J.A., Alasino, P.H., Galindo, C., Pankhurst, R.J., Rapela, C.W., Saavedra, J., Casquet, C., Baldo, E., González Casado, J.M., 2006. Evolución magmática del granito Peñón Rosado, cerro Asperecito, flanco occidental de la sierra de Famatina. Rev. Asoc. Geol. Argent. 61 (1), 93-111.

Dalziel, I.W.D., 1997. Neoproterozoic-Paleozoic geography and tectonic review, hypothesis, environmental speculation. Geol. Soc. Amer. Bull. 109, 16-42.

Debon, F., Le Fort, P., 1983. A chemical-mineralogical classification of common plutonic rocks and associations. Trans. R. Soc. Edinb. Earth Sci. 73, 135-149.

Deer, W.A., Howie, R.A., Zussman, J., 1992. An Introduction to the Rock Forming Minerals, Second Longman Editions. Longman, London, p. 696.

DePaolo, D.J., Linn, A.M., Schubert, G., 1991. The continental crustal age distribution: methods of determining mantle separation ages from $\mathrm{Sm}-\mathrm{Nd}$ isotopic data and application to the southwestern United States. J. Geophys. Res. 96, 2071-2088.

Droop, G.T.R., 1987. A general equation for estimating $\mathrm{Fe}^{3+}$ in ferromagnesian silicates and oxides from microprobe analyses, using stoichiometric criteria. Mineral. Mag. 51, 431-437.

du Bray, E.A., 1988. Garnet compositions and their use as indicators of peraluminous granitoid petrogenesis — southeastern Arabian Shield. Contrib. Mineral. Petrol. 100, 205-212.

du Bray, E.A., 1994. Composition of micas in peraluminous granitoids of the eastern Arabian Shield. Contrib. Mineral. Petrol. 116, 381-397.

Fujimaki, H., Tatsumoto, M., Aoki, K.-i., 1984. Partition coefficients of Hf, $\mathrm{Zr}$, and REE between phenocrysts and groundmasses. J. Geophys. Res. 89, 662-672.

Ganguly, J., Saxena, S.K., 1984. Mixing properties of aluminosilicate garnets: constraints from natural and experimental data, and applications to geothermo-barometry. Am. Mineral. 69, 88-97.

Ghiorso, M.S., Carmichael, I.S.E., 1987. Modeling magmatic systems: petrologic applications. Reviews in mineralogy. Mineral. Soc. Am. 17, 467-499.

Gomes, M.E.P., Neiva, A.M.R., 2005. Geochemistry of granitoids and their minerals from Rebordelo-Agrochao area, northern Portugal. Lithos 85, 235-254.

Gradstein, F., Ogg, J., Smith, A., 2004. A Geologic Time Scale 2004. Cambridge University Press, Cambridge, UK. 589 pp. 
Guowei, Xu, Will, T.M., Powell, R.A., 1994. Calculated petrogenetic $\mathrm{K}_{2} \mathrm{O}-\mathrm{FeO}-\mathrm{MgO}-\mathrm{Al}_{2} \mathrm{O}_{3}-\mathrm{SiO}_{2}-\mathrm{H}_{2} \mathrm{O}$, with particular reference to contact metamorphosed pelites. J. Metamorph. Geol. 12, 99-119.

Hanson, G.N., 1978. The application of trace elements to the petrogenesis of igneous rocks of granite composition. Earth Planet. Sci. Lett. 38, 26-43.

Harrison, T.N., 1988. Magmatic garnets in the Cairngorm granite, Scotland. Mineral. Mag. 52, 659-667.

Hogan, J.P., 1996. Insights from igneous reaction space: a holistic approach to granite crystallization. Trans. R. Soc. Edinb. Earth Sci. 87, 147-157.

Hoisch, T.D., 1990. Empirical calibration of six geobarometers for the mineral assemblage quartz + muscovite + biotite + plagioclase + garnet. Contrib. Mineral. Petrol. 104, 225-234.

Hollister, L.S., 1966. Garnet zoning: an interpretation based on the Rayleigh fractionation model. Science 154, 1647-1651.

Holtz, F., Johannes, W., 1991. Genesis of peraluminous granites I. Experimental investigation of melt composition at 3 and $5 \mathrm{~kb}$ and various $\mathrm{H}_{2} \mathrm{O}$ activities. J. Petrol. 32, 935-958.

Jarosewich, E.J., Nelen, J.A., Norberg, J.A, 1980. Reference samples for electron microprobe analysis. Geostand. Newsl. 4, 43-47.

Johannes, W., Ehlers, C., Kriegsman, L.M., Mengel, K., 2003. The link between migmatites and S-type granites in the Turku area, southern Finland. Lithos 68, 69-90.

Jordan, T.E., Allmendiger, R.W., 1986. The Sierras Pampeanas of Argentina: a modern analogue of Rocky Mountain foreland deformation. Am. J. Sci. 286, 737-764.

Kebede, T., Koeberl, C., Koller, F., 2001. Magmatic evolution of the Suqii-Wagga garnet-bearing two-mica granite, Wallagga area, western Ethiopia. J. Afr. Earth Sci. 32, 193-221.

Kretz, R., 1983. Symbols for rock-forming minerals. Am. Mineral. 68, 277-279.

Leake, B.E., 1967. Zoned garnets from the Galway granite and its aplites. Earth Planet. Sci. Lett. 3, 311-316.

Manning, D.A.C., 1983. Chemical variation in garnets from aplites and pegmatites, peninsular Thailand. Mineral. Mag. 47, 353-358.

McCarthy, T.S., Groves, D.I., 1979. The Blue Tier Batholith, northeastern Tasmania: a cumulate-like product of fractional crystallization. Contrib. Mineral. Petrol. 71, 193-209.

McCarthy, T.S., Robb, L.J., 1978. On the relationships between cumulus mineralogy and trace and alkalis element chemistry in a Archean granite from Barbeton region, South Africa. Geochim. Cosmochim. Acta 42, 21-26.

McGuire, A.V., Francis, C.A., Diar, M.D., 1992. Mineral standards for electron microprobe analysis of oxygen. Am. Mineral. 77, 1087-1091.

McMullin, D., Berman, R.G., Greenwood, H.J., 1991. Calibration of the SGAM thermobarometer for pelitic rocks using data from phase equilibrium experiments and natural assemblages. Can. Mineral. 29, 889-908.

Miller, C.F., Stoddard, E.F., 1981. The role of manganese in the paragenesis of magmatic garnet: an example from the Old Woman Piute Range, California. J. Geol. 89, 233-246.

Miller, C.F., Stoddard, E.F., Bradfish, L.J., Dollase, W.A., 1981. Composition of plutonic muscovite: genetic implications. Can. Mineral. 19, 25-34.

Miller, C.F., McDowell, S.M., Mapes, R.W., 2003. Hot and cold granites? Implications of zircon saturation temperatures and preservation of inheritance. Geology 31, 529-532.

Nagasawa, H., Schnetzler, C.C., 1971. Partitioning of rare earth, alkali and alkaline earth elements between phenocrysts and acidic igneous magma. Geochim. Cosmochim. Acta 35, 953-968.
Nakamura, N., 1974. Determination of REE, Ba, Fe, Mg, Na and K in carbonaceous and ordinary chondrites. Geochim. Cosmochim. Acta $38,757-775$.

Nash, W.P., Crecraft, H.R., 1985. Partition coefficients for trace elements in silicic magmas. Geochim. Cosmochim. Acta 49, 2309-2322.

Pankhurst, R.J., Rapela, C.W., Saavedra, J., Baldo, E., Dahlquist, J., Pascua, I., Fanning, C.M., 1998. The Famatinian magmatic arc in the central Sierras Pampeanas: an Early to Mid-Ordovician continental arc on the Gondwana margin. In: Pankhurst, R.J., Rapela, C.W. (Eds.), The Proto-Andean Margin of Gondwana. Geol. Soc. (London), Special Publications, vol. 142, pp. 343-367.

Pankhurst, R.J., Rapela, C.W., Fanning, C.M., 2000. Age and origin of coeval TTG, I- and S-type granites in the Famatinian Belt of NW Argentina. Trans. R. Soc. Edinb. Earth Sci. 91, 151-168.

Patiño Douce, A.E., 1996. Effects of pressure and $\mathrm{H}_{2} \mathrm{O}$ content on the compositions of primary crustal melts. Trans. R. Soc. Edinb. Earth Sci. 87, 11-21.

Patiño Douce, A.E., Beard, J.S., 1996. Effects of $P, f\left(\mathrm{O}_{2}\right)$ and $\mathrm{Mg} / \mathrm{Fe}$ ratios on dehydration melting of model metagreywackes. J. Petrol. 37, 999-1024.

Patiño Douce, A.E., Harris, N., 1998. Experimental constraints on Himalayan anatexis. J. Petrol. 39, 689-710.

Pattison, D.R.M., Tracy, R.J., 1991. Phase equilibria and thermobarometry of metapelites. In: Kerrick, D.M. (Ed.), Contact Metamorphism. Reviews in Mineralogy. Mineral. Soc. Am., vol. 26, pp. 105-206.

Rapela, C.W., Shaw, D.M., 1979. Trace and major element models of granitoid genesis in the Pampean Ranges, Argentina. Geochim. Cosmochim. Acta 43, 1117-1129.

Rapela, C.W., Pankhurst, R.J., Casquet, C., Baldo, E., Saavedra, J., Galindo, C., Fanning, C.M., 1998a. The Pampean Orogeny of the southern proto-Andes: evidence for Cambrian continental collision in the Sierras de Córdoba. In: Pankhurst, R.J., Rapela, C.W. (Eds.), The Proto-Andean Margin of Gondwana. Geol. Soc. (London), Special Publication, vol. 142, pp. 181-217.

Rapela, C.W., Pankhurst, R.J., Casquet, C., Baldo, E., Saavedra, J., Galindo, C., 1998b. Early evolution of the proto-Andean margin of South America. Geology 26, 707-710.

Richard, L.R., 1995. Mineralogical and petrological, data processing system for Windows, version 2.02. Minpet Geological SoftwareLogiciel Géologique Minpet, Quebec.

Rollinson, H.R., 1993. Using geochemical data: evaluation, presentation, interpretation. Longman Scientific \& Technical Editions, Singapore, p. 352.

Sawyer, E.W., 1987. The role of partial melting and fractional crystallization in determining discordant migmatite leucosome compositions. J. Petrol. 28, 445-473.

Sims, J.P., Ireland, T.R., Camacho, A., Lyons, P., Pieters, P.E., Skirrow, R.G., Stuart-Smith, P.G., 1998. U-Pb, Th-Pb and $\mathrm{Ar}-\mathrm{Ar}$ geochronology from the southern Sierras Pampeanas, Argentina: implications for the Palaeozoic tectonic evolution of the western Gondwana margin. In: Pankhurst, R.J., Rapela, C.W. (Eds.), The Proto-Andean Margin of Gondwana. Geol. Soc. (London), Special Publication, vol. 142, pp. 259-281.

Spear, F.S., 1993. Metamorphic phases equilibria and pressuretemperature-time paths. Mineral. Soc. Am., Monogr. 1, 779 Washington, USA.

Speer, J.A., 1984. Micas in igneous rocks. Reviews in mineralogy. Mineral. Soc. Am. 13, 357-368.

Steiger, R.H., Jäger, E., 1977. Subcommision of geochronology: convention on the use of decay constants in geo- and chosmochronology. Earth Planet. Sci. Lett. 1, 369-371. 
Streckeisen, A., 1976. To each plutonic rock its proper name. Earth. Sci. Rev. 12, 1-33.

Sylvester, P.J., 1998. Post-collisional strongly peraluminous granites. Lithos 45, 29-44.

Tera, F., Wasserburg, G., 1972. U-Th-Pb systematics in three Apollo 14 basalts and the problem of initial $\mathrm{Pb}$ in lunar rocks. Earth Planet. Sci. Lett. 14, 281-304.

Thomas, W.A., Astini, R.A., 1996. The Argentine precordillera: a traveller from the Quachita embayment of North America Laurentia. Science 273, 752-757.

Vance, J.A., 1962. Zoning in igneous plagioclase: normal and oscillatory zoning. Am. J. Sci. 260, 746-760.

Vernon, R.H., Richards, S.W., Collins, W.J., 2001. Migmatite-granite relationships: origin the Cooma Granodiorite magma, Lachlan Fold Belt, Australia. Phys. Chem., Earth (A) 26, 267-271.

Vielzeuf, D., Holloway, J.R., 1988. Experimental determination of the fluid-absent melting relations in the pelitic system. Contrib. Mineral. Petrol. 98, 257-276.
Villaseca, C., Barbero, L., Herreros, V., 1998. A re-examination of the typology of peraluminous granite types in intracontinental orogenic belts. Trans. R. Soc. Edinb. Earth Sci. 89, 113-119.

Walker, J.A., Carr, M.J., 1986. Compositional variations caused by phenocryst sorting at Cerro Negro volcano, Nicaragua. Geol. Soc. Amer. Bull. 97, 1156-1162.

Williams, I.S., 1998. U-Th-Pb geochronology by ion microprobe. In: McKibben, M.A., Shanks, W.C. (Eds.), Applications of Microanalytical Techniques to Understanding Mineralising Processes. Rev. Econ. Geol., vol. 7, pp. 1-35.

Wyborn, D., Turner, B.S., Chappell, B.W., 1987. The Boggy Plain supersuite: a distinctive belt of I-type igneous rocks of potential economic significance in the Lachlan Fold Belt. Aust. J. Earth Sci. $34,21-43$.

Yardley, B.W.D., 1977. An empirical study of diffusion in garnet. Am. Mineral. 62, 793-800. 